Historic, Archive Document

Do not assume content reflects current scientific knowledge, policies, or practices. 
62.43

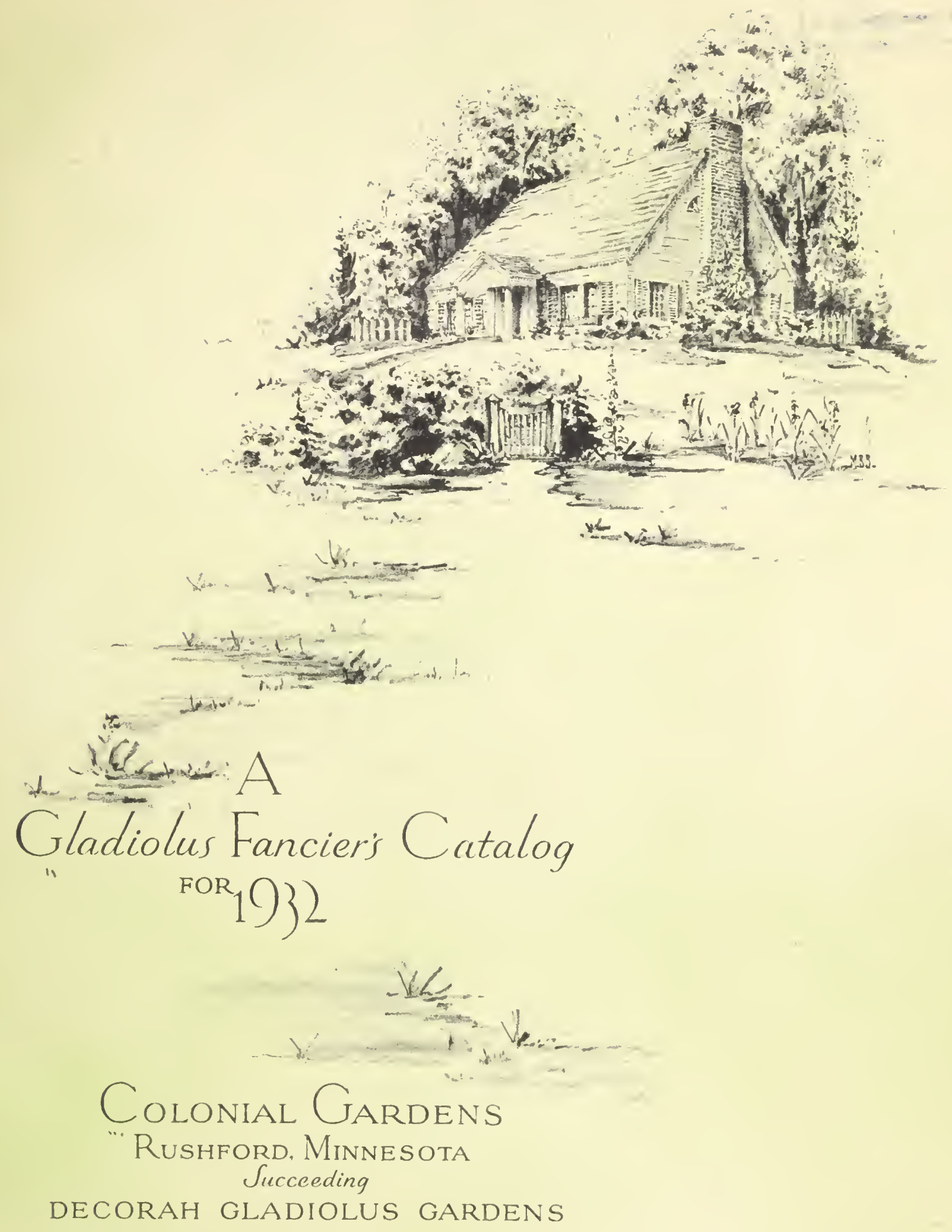




\section{A Garden}

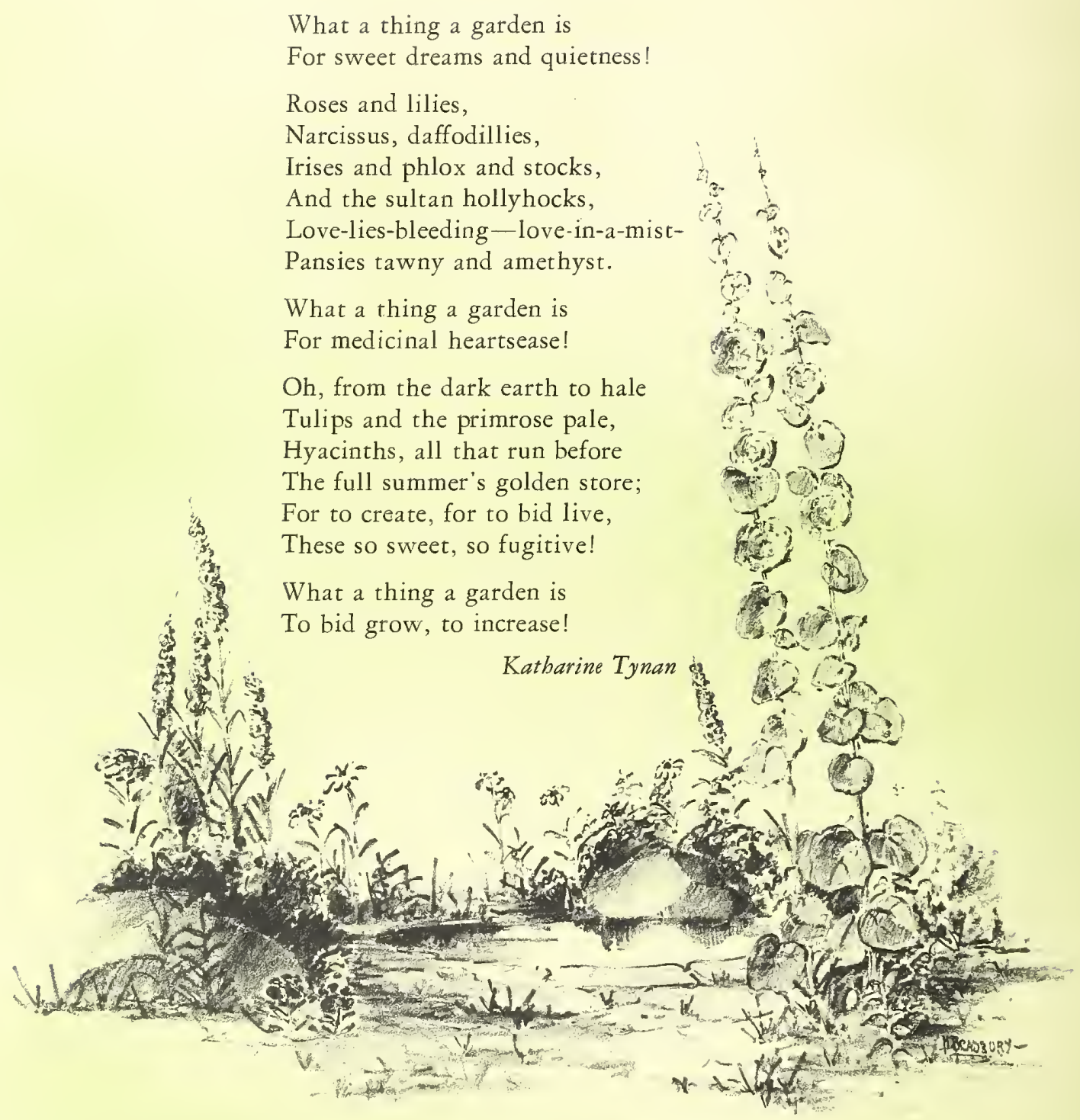





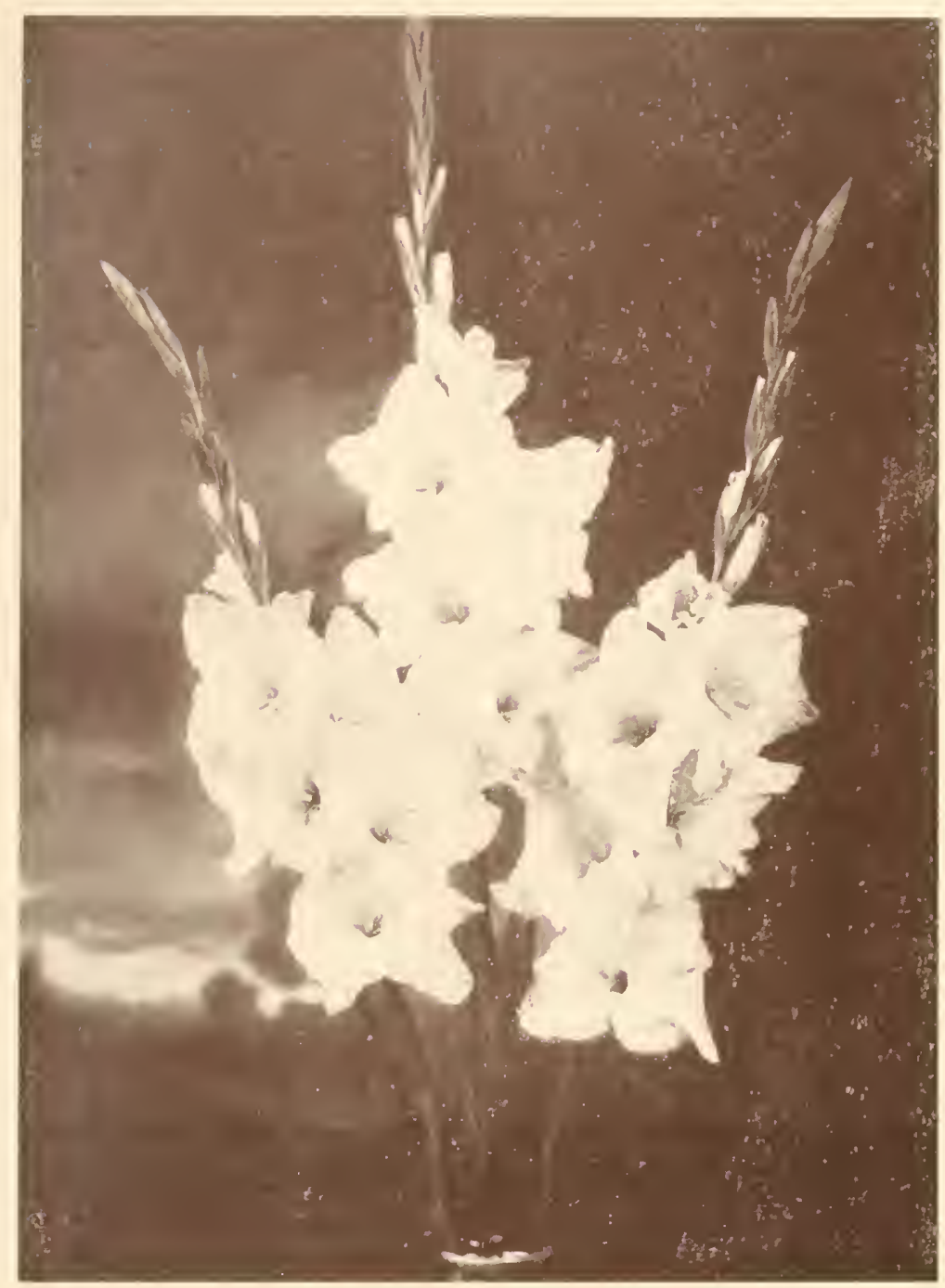

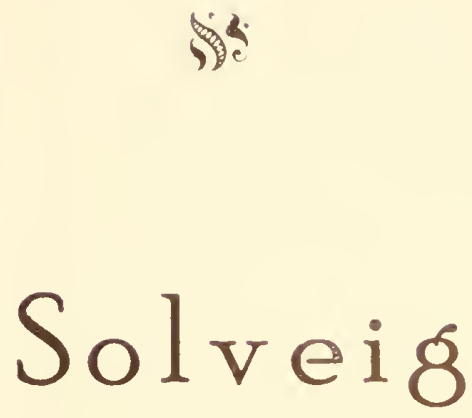

The World's Premier

White Gladiolus

\author{
$-\mathrm{O}-$ \\ One \\ of But Two Seedlings \\ Awarded \\ THE FIRST CLASS \\ CERTIFICATE \\ of the
}

American Gladiolus Society

Since 1916

Our Only Introduction

for 1932

HE 1931 show of the American Gladiolus Society was held in the Cleveland municipal auditorium. the finest and second largest public hall in Anerica. The entire main floor of this enormous building, which with its arcade and annex covers three city blocks, was filled with a profusion of beautiful flowers, most of them being gladioli, of which there were over 10,000 separate entries. It was stated by A. G. S officials and European visitors alike to have been the finest gladiolus show ever staged in either America or Europe. The seedling division was said to be the strongest ever seen at a National A. G. S. show.

In the face of this tremendous competition. SOL VEIG won the highest honors in the exhibition seedling division - a First Class Certificate - and was admittedly the sensation of the show. SOLVEIG was not only generally referred to as the finest gladiolus on exhibition at Cleveland. but several fanciers of national prominence spoke of it as the most nearly perfect gladiolus they had ever seen.

Such high commendation bespeaks the quality of the flower more effectively than any description we can give or any picture that we could reproduce.

At the time it was judged, the spikes of SOLVEIG. which had just been unpacked. had but three florets open each, but in spite of this it scored 93 points - six points higher than any other exhibition seedling. One of the judges told us that if SOLVEIG had had six florets open, it would have scored 95 per cent. Since we have frequently had it with that number open. even in the open field, we believe that this 
may be taken as a fair rating for SOLVEIG. In the face of the rigid new A. G. S. scoring system, we question whether any other gladiolus now in commerce can equal this rating ..... Altho we advertise SOLVEIG as "the world's premier white gladiolus," beyond all doubt its true premiership extends far beyond the realm of white gladioli.

The real quality of SOLVEIG lies in its snowy white color, lit up in the throat with just the slightest touch of bright rose, lies in its unbelievably heavy substance which has the glossy sheen of white velvet, in its round, flat blooms, and unique, informal ruffling. In the strictest sense of the word, SOLVEIG is not an exhibition type of glad-one that opens up twelve or fifteen four or five inch, close-set florets at one time. It is rather a commercial type developed to the largest exhibition size. A spike of SOLVEIG with five or six florets open is fully as large as a specimen spike of $W . H$. Phipps. This is because its florets, which are a good six inches in diameter, are so round that they look even larger than seven inch florets of the winged or triangular type. Also, the blooms are set so far apart that they frequently barely touch, not being crowded together or overlapped as is the case with most exhibition sorts. These features not only give SOLVEIG giant size, but confer a degree of poise or style that is most unusual. The exceedingly heavy texture is another quality which contributes a great deal to the effect of massiveness. glads.

For richly exquisite beauty and fine precision of form, SOLVEIG is without a peer in the world of modern

\section{The Future of Solveig}

Altho SOLVEIG is supreme on the show table, its biggest future undoubtedly lies in the commercial field. White glads are today coming strongly into vogue, and when a variety of the quality of SOLVEIG becomes available in commercial quantity, the demand for it is sure to be tremendous.

SOLVEIG has every qualification for becoming an ideal commercial cut-flower:

The plant is a very robust grower, reaching a height of about five feet.

The strong, wiry stem never crooks or lops over in the field, and can be cut quite low with safety.

The spikes ship well (on account of the buids lying close to the stem) and bloom out well in water, as the spikes carried from Minnesota to Cleveland well demonstrate.

Florets do not burn in extreme heat. We know of few glads besides SOLVEIG that can stand in the open field when it is $100^{\circ}$ in the shade (as last summer) and show no sign of drooping at mid-day.

Small bulbs throw remarkably large blooms. (See accompanying illustration).

Spikes do not become stubby in dry weather.

Placement is very regular.

\section{Solveig Produces Practically 100\% Cuttable Bloom}

Pronunciation: The name SOLVEIG, which is a classic Norse term meaning "Sunny Way". is pronounced with the sound of a long "o" and a long "a": Sol-vag. 


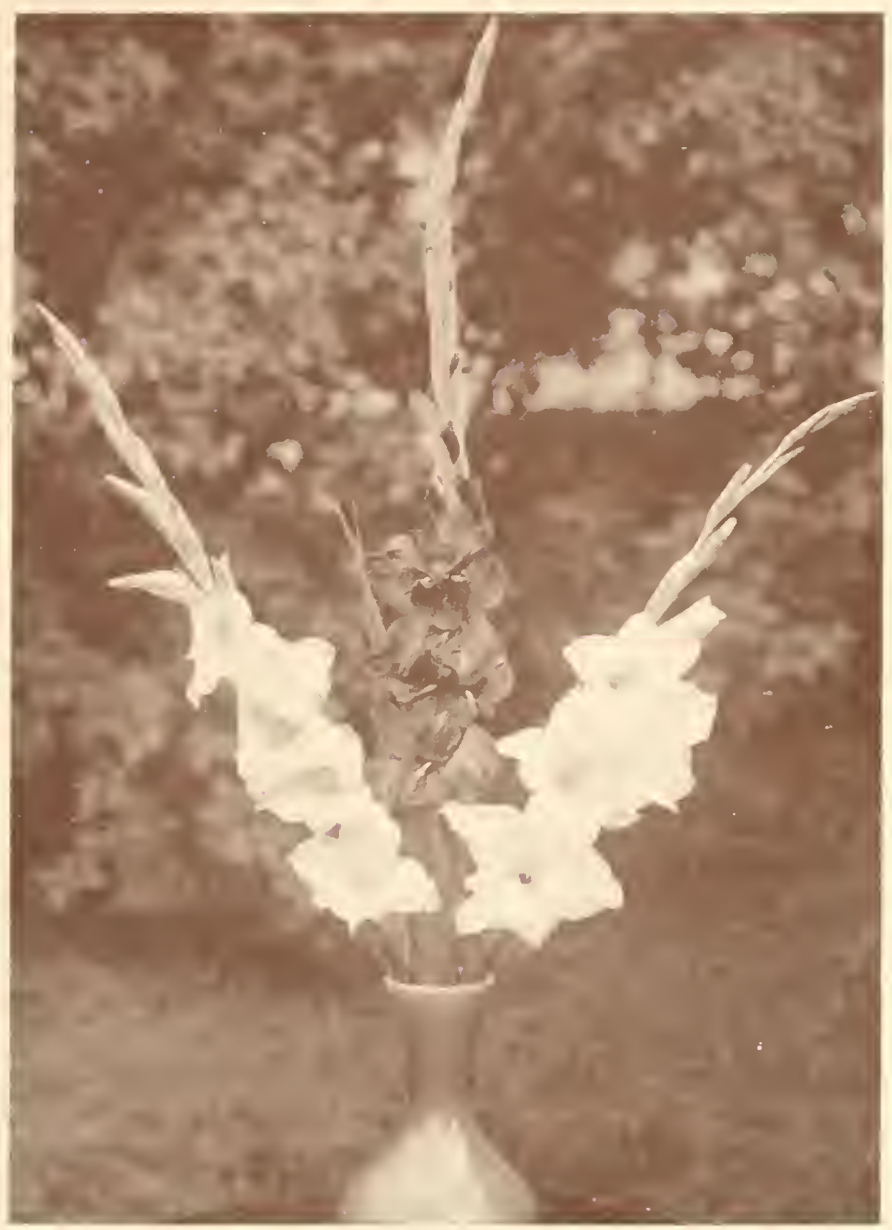

SHOWING THE PRECOCITY OF SOLVEIG
The Price of SOLVEIG

Is

$\$ 50.00$ per Bulb, net. for Nos. 1, 2, or 3

No smaller bulbs or bulblets will be sold.

Gowers and fanciers who would like more detailed information about SOLVEIC are alcised to write for our specinl illustrated folder.

In the adjoining picture, the spike of SOLVEIG (right) was grown from a "No. 7" bulb, planted in a special seedbed along with our bulblets. The other two spikes are first class specimens of two of our best standard glads, Mrs. Norton and Dr. F. E. Bennett, both grown from No. 1 bulbs. Note that SOLVEIG makes a fine spike from even a very small bulb. This is an important consideration in a commercial gladiolus.

\section{What Some of the Experts Have Said About This Remarkable Flower}

"It looks to me by far the best thing that Mr. Prestgard has ever put out, and if it is as good as it looked at Cleveland, it is surely the best white I have ever seen, and I think I have seen all the good ones."

Elmer E. Gore

"There can be no question that SOLVEIG is a world-beater."

-John II. Lewis

"Along with Picardy, it is the finest introduction since Minuet."

-G. W: 'Thacker'

"The finest glad at the Cleveland show was SOLVEIG."

-F. Malcolm Reid -William Schmidt, Jr.

-Frank 1. Plat

"SOLVEIG won the blue ribbon in competition among the finest collection of seedlings I have ever seen at the National Show .... I believe I have never seen three spikes exhibited in the same vase showing the perfection of SOLVEIG. I predict for it a great future, both as an exhibition flower and as a commercial variety." 


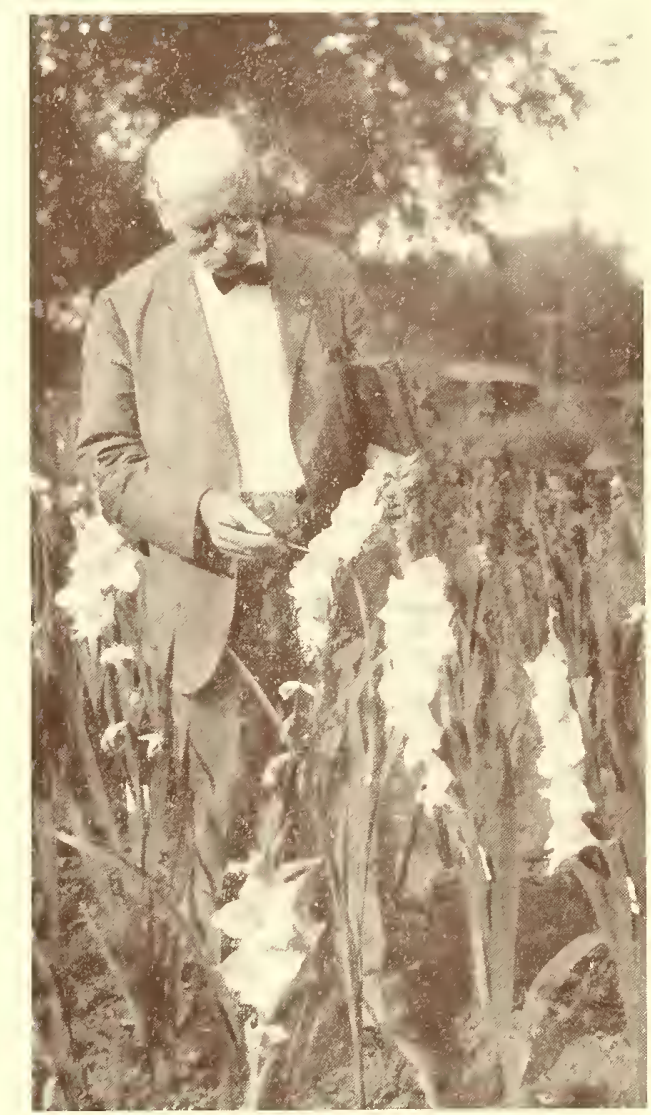

A picture taken several years ago, showing $M r$. Prestgard engaged in the kind of work that produced SOLVEIG. Mr. Prestgard uses a eamel's hair brush in his hybridizing, dusting off the dry pollen between operations. Under his arm may be seen the kit in whieh he earries (each in its separate pill box) the pollcn of vrieties which he wishes to use for his crosses of that day.

\section{A Few Facts About the}

\section{Originator of Solveig}

Mr. Prestgard is one of America's oldest and best-known hybridizers. We do not know how many years he grew glads as a fancier before taking up the actual crossing of the flower's, but SOLVEIG, as a 1932 introduction, comes as the culmination of 29 years of continuous, patient work of actual hybridizing. During these years hundreds of thousands of seedlings have been grown and tested, and all save a very few discarded. Mr. Prestgard has always been considered a "hard boiled" but very fair judge of seedlings and has often in previous years acted as judge in the seedling division in national shows. He has always been very conservative in estimating the merits of his own seedlings - and conservative about prices as well. So when Mr. Prestgard insisted that SOLVEIG be sold for not less than $\$ 50$ each, it was not a departure from his former price standards but a recognition of the fact that SOLVEIG was so extraordinary a break in quality that it essentially set a new standard for the gladiolus.

Although we have many Decorah seedlings under test, we plan to introduce but one or two of the very best each year. This is in accord with Mr. Prestgard's own advice that on account of the tremendous number of glads now in commerce only the most outstanding sorts should be introduced in the future. SOLVEIG is unquestionably the finest of the Decorah seedlings though there are several others in other colors that wa feel sure will prove leaders in their classes. 


\section{To the Many Friends and Customers of}

\section{Decorah Gladiolus Gardens}

\section{GREETINGS:}

This is to tell you that the Decorah Gladiolus Gardens, Decorah, Iowa, has this fall sold its entire holding and everything that goes with it, to the Colonial Gardens of Rushford. Minnesota.

The reasons why? you ask.

They are only too evident. The steadily growing business end of the glad game together with my other rather strenuous work as a newspaper editor became too much for me, especially as the years were piling up on me shamefully fast. And the loss of my friend and partner. Dr. Hoeg, last year, left me with an additional burden. And so I-with sort of a brave smile-turned over our glad business and care and all the hard work of the game to my young friend ir. Rushford, Mr. Ralph Baerman, which transaction only means, that the old glad concern of Dzcorah simply was moved bodily over the Minnesota line, where it was merged with Mr. Baerman's own fine collection of the most outstanding novelties from all over the world, and where it continues under the new name.

I did not hesitate in making this change as I felt certain that the kindness and confidence shown Decorah Glad Gardens through so many, many years by its friends and customers all over the globe, will be transferred in full measure to the new concern in Rushford. Mr. Baerman is not a new man in the glad game. He has been a grower for many years and has made a study of most of the best varieties in the world today. As proof of my faith and confitence in his ability, honesty, and integrity, I have retained some financial interest in the new concern. I feel sure he will put Rushford on the map-in the most enviable sense of the word.

Among the stock turned over to the Colonial Gardens were a great number of new seedlings, never before seen outside our gardens here in Decorah. They were in different stages of propagation. Only one of them was introduced to the glad fraternity this fall: SOLVEIG. I understand that its fame already is traveling fast to the farthermost corners of our globe. Mr. Baerman will, from year to year, release others of the many new seedlings included in the deal, and I shall not be surprised if some of them will - if not exactly repeat the performance of Solveig - come pretty close to it.

You ask if all this means that I have given up the glad game for good?

I'll say not! How could I? If I should give up the most fascinating part of the game: hybridizing and watching results and swimming joyously around in the midst of an ocean of colors every: season - why, then life would be dreary, indeed. And then there is always the golden hope lingering in the mind: that some day I may have the good fortune to produce something new that will be termed a worthy companion of young SOLVEIG. If that hap sens, you very likely will hear the glad news through the Colonial Gardens.

And so--as I thank you most heartily, all good glad friends, for the glorious time we have had together for so many, many years, I do not say go dbye but "auf wiedersehn"!

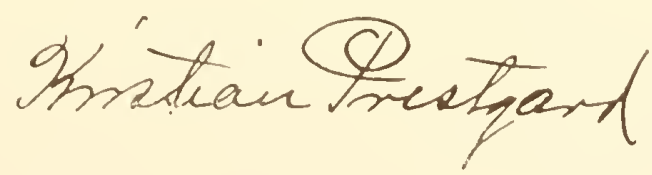




\section{Decorah Varieties}

While complete descriptions and information about Decorah varieties is contained in our general list, we tabulate the entire group here intact, with prices, for convenient reference. One dozen may be had at ten times the unit price.

Anitra (Sm.) - light perilla purple with cream throat; excellent grower ..............................\$ .20

Blue Boy (L.V.) - one of the bluest glads in existence; throat marking of purple on light yellow 1.00

Buffalo Bill (L.) - excellent tall lavender; ideal for

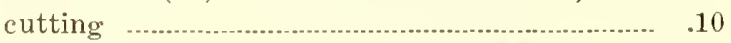

Carmen Sylva (W.) - the standard commercial

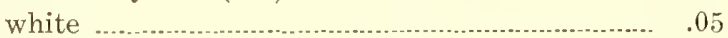

Charles Lindbergh (P.P.) - one of the aristocrats of the glad family; Hermosa pink with large, almost white throat. Fine tall grower ................... 2... 2.00

Dark Eye (D.R.)—deep maroon ...................... .35

Decoration (E.E.)-splendid cameo pink that bids fair to become a leading commercial............. .35

Dorothy Vernon (Cr.) - cream with golden throat;

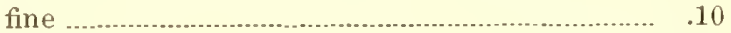

Earl Benbow (W.)-beautiful new white variety; only ten bulbs for sale this year ................... 1.00

Gettysburg (D.R.) —fine large maroon .............. 10

Gold (Y.) —an old-favorite light yellow ......... .07

Grace E. Kimball (L.V.)-pale Hortense violet with

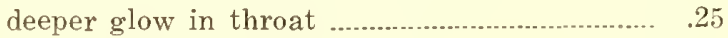

Honeydew (Lac.) — a soft apricot-yellow; one of the best laciniated glads ....................................... $\quad .10$

Jane Addams (L.) -named after the co-winner, this year, of the Nobel Peace Prize. A giant phloxpink or lavender with white throat; fine velvety substance. Down to a low price for the first time this year .15
Jap Lady (D.V.) —an unusual Bishop purple

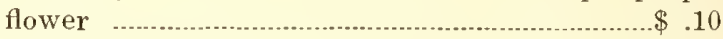

Jenny Lind (S.P.) - salmon with a golden throat; a fine old favorite. We offer only the tall strain .05

Longfellow (P.P.) - a popular pure pink glad, fine

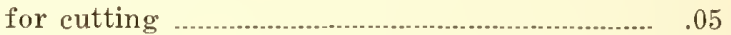

Lotus (L.P.) - a medium-sized glad of great beauty; palest pink with creamy throat ….................. .25

Madam Norena (Cr.) - beautiful ruffled apricot with yellow throat ...........................................................

Mandarin (O.) -orange with a yellow throat... .07

Miss Des Moines (L.) - lively lavender with many

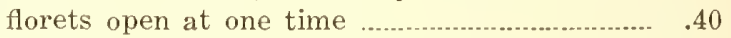

Montenegro (D.R.) - one of the blackest glads in existence. Velvety deep maroon........................ .15

Mrs. Kristian Prestgard (W.) - waxy ruffled white

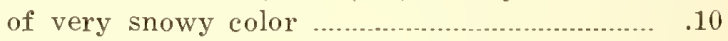

Norma Talmadge (Y.) —giant sulphur yellow.... $\quad .10$

Roald Amundsen (R.)-light spectrum red selfcolor; splendid substance and heavy ruffling.... .35

Sigrid Undset (L.) - palest lavender with very many florets open at one time ............................. .75

SOLVEIG (W.)-previously described............. 50.00

Srengali (Sm.) - deep hellebor red with pomegranate purple throat; an outstanding smoky ........ 50

Terracotta (Sm.) - Van Dyke red with a rich

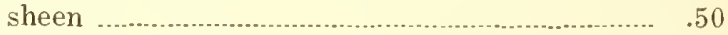

Trilby (Cr.)-heavily ruffled light buff with rich yellow throat. A very fine glad........................ . .10

Offers of prize bulbs made by the Decorah Gladiolus Gardens for last summer's shows will be honored by the Colonial Gardens. Please make your selections from Decorah originations.

Mr. Prestgard's story of the origin of the SOLVEIG which we promised for our catalog proved too long to fit into the space we had reserved for it. It will appear instead in an early issue of the Gladiolus Review, probably in the February number. We feel safe in saying that you will find this one of the most interesting and important articles on hybridizing ever published in the Review.

Some of the features of this catalog have been adapted, by permission, from the iris catalogs of the late F. X. Schreiner. Glad fans who would be interested in securing a similar service with reference to iris, are advised to write to Robert Schreiner, Route 1, Riverview Sta., St. Paul, Minn. 


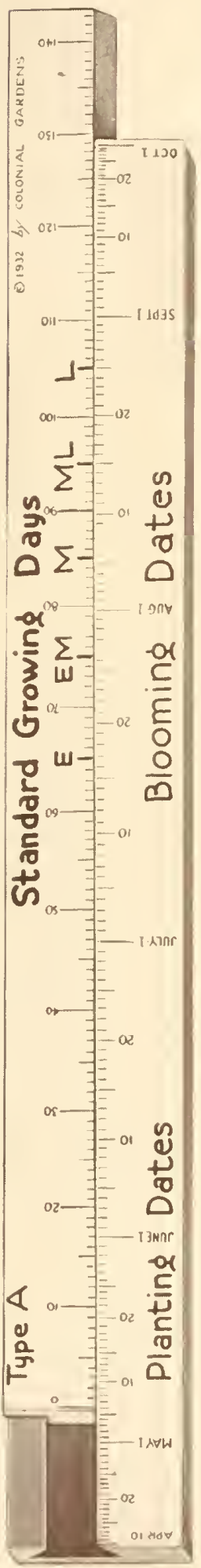

ำำ

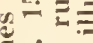

疍

ऍ屯.

芫

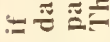

战

拝

管

党航

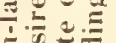
要

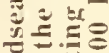

드르르.

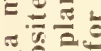

๘

$z$

政

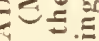

的苔象

然

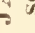

气气

\&

\section{Announcing An Invention \\ Of Value to Every Gladiolus Lover:- \\ the \\ Gladiolus Slide Rule}

\author{
For Timing Gladiolus Blooms for Exhibitions
}

\begin{abstract}
This valuable new device will not only save you counting days on the calendar but will automatically make the correct allowance for the difference in growing-day value between cool spring weather and the hot days of midsumner.
\end{abstract}

Graduations on the rule are based on the blooming season of No. 1 bulbs planted at an average depth. Proper allowance can be made for smaller bulbs or for different planting-depth. There are two types of rules: one for latitudes north of Chicago and one for latitudes south of Chicago.

The Gladiolus Slide-Rule is valuable to every glad fan and indispensable to every exhibitor and hybridizer. If you have not previously been an exhibitor, the Gladiolus Slide Rule will help you to have your finest varieties in blossom for your State or local show.

The price of the Slide-Rule, carefully manufactured from hard maple, with an ordinary 12 inch rule on the reverse, attractively boxed, and with complete directions, is $\$ 3.00$. Please specify whether you want the Northern or Southern type.

Your slide rule device appeals to me as a very simple and quick method of determining when a varicty planted on a certain date, should bloom, ard conversely, when the desired blooming date is linown, just when it is desirable to plant the variety. It is a handy device which I have no daubt a great many people will make use of.

-E. F. PALMER.

\section{EXTRA SPECIAL OFFER!}

Since this is the first catalog to be issued by the Colonial Gardens since our merging with the Decorah Gladiolus Gardens, we are particularly desirous of signalizing the occasion by an especially generous offer, both to our own old customers and those of the Decoral Gardens and to the new patrons which we hope to win this season.

We have, therefore, decided to give the Gladiolus Slide-Rule entirely without charge to every fan who sends us an order for not less than $\$ 5.00$ accompanied by cash in full, or to everyone who sends us an order of $\$ 10.00$ or over accompanied by a $25 \%$ deposit.

Send us your order now and we will send you the slide-Rule im. mediately, holding your bulbs for shipment at any later date which you may desire. 


\section{Foreword to General List}

\section{Please Read This Important Explanation Of Our Catalog}

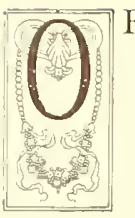

F THE 7,000 named varieties of glads mentioned in the official A. G. S. Nomenclature, nearly 3,000 are in actual commerce today. To this number is being added the world over approximately 300 new varieties each year. This flood of new sorts has practically swamped the glad fancier and developed in him a vely skeptical, "show-me" attitude toward anything new. Fans realize that any year that brings forth twentyor even ten-worth-while new things, is making a remarkable record for itself.

It wouldn't be so bad if every new variety were not praised in superlative terms, but they all are, and there has been nothing left for the fan to do but to "weigh adjectives"-immense against gigantic, superb against magnificent-in an effort to determine which glads he wanted to buy. True, there have been symposiums, and we are strong believers in these popularity contests, but as a rule a variety has to be five or six years old, even if most outstanding, before it is well enough known to win a place near the top. So a symposium, tho valuable, hardly suffices for up-to-date information.

In the section of our catalog which follows, we have devised a complete system of up-tothe-minute recommendations of the best varieties for fancier, exhibitor, or commercial grower. We believe that it will be a great help to every glad grower who wants to get more gladiolus pleasure for his money. But before I explain our tabulated system of recommendations, let me tell you how they were arrived at.

For several years we have been following every symposium conducted both in this country and abroad, we have been attending as many glad shows as possible, we have been corresponding with a great many fanciers and with practically every well-known hybridizer the world over. All the information picked up in this way has been supplemented by an actual garden test of approximately 1500 of the most talked-of varieties. This has given us an accurate and up-to-date knowledge of what are today THE WORLD'S LEADING VARIETIES OF GLADS.

Needless to say, in presenting this information, I have made every effort to be strictly impartial. This is not only a matter of pride with me, but-as you will realize that I must realize-a necessity if our catalog is going to mean a thing. There is no correlation whatever between the size of our stock of any given variety and the recommendation that that variety receives in our catalog. Of some sorts listed in the first 100 as SUPER GLADS, the Colonial Gardens hasn't a half a dozen bulbs (tho we can get more) ; other things like Le Marechal Foch and Alice Tiplady do not appear in even our list of the best 500, tho we had very large stocks of these varieties.

The following is a complete key to our tabulated data and recommendations:

\section{Key}

All recommendations are based on beauty, performance, and distinctiveness.

If you are a typical fancier-preferring the large exhibition type of flower but also enjoying some smaller ones, willing to fuss with an occasional temperamental beauty, but appreciating regular cut-flower performance-go by the SIZE OF TYPE in which variety names are printed, in making your selections.

If you are primarily an exhibitor, interested chiefly in giant flowers, pay more attention to the SIZE COLUMN.

If you are a commercial grower and want the most regular performance and good cut-flower qualities, go by the NUMBER OF ASTERISKS after the names. 
From the standpoint of the typical fancier, we have listed:

100 Super Glads (in heavy capitals)

200 Group A Glads (in light capitals)

200 Group B Glads (in regular type).

making a total of what we believe to be the 500 leading varieties for 1932 .

All data as to year of introduction was secured direct from the originators, which fact enabled us to fill in many of the blanks appearing in the Nomenclature and to correct numerous inaccuracies. Blooming seasons were also received from all originators and correlated with our own and other records.

The scale for size includes size of florets, number open at one time, and length of flower-head - in other words, general size effect:

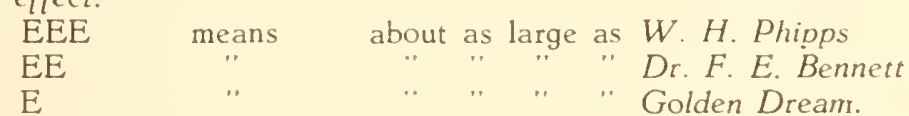

Substance or thickness of petals, which is usually, but not always, an important feature in the beauty of a glad, is rated as follows:
A
B
,
very heavy (as Purple Glory)
heavy (as Dr. Bennett)
C
moderate (as W. H. Phipps).

Commercial merit is indicated by asterisks:

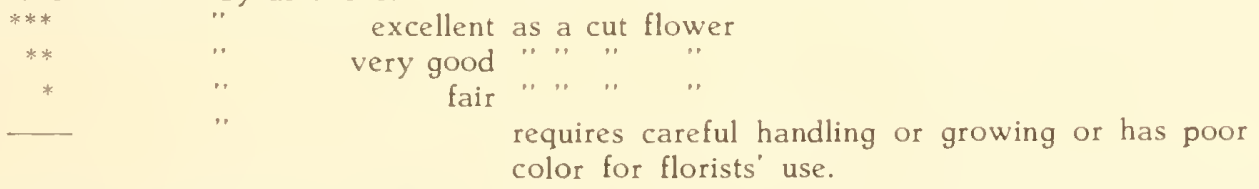

"Unit Price" means for one young No. 1 bulb. In ordering you may select any size and quantity from the complete price schedule on the inside back cover of this catalog.

It will be observed that we have included several very new varieties in our recommendations of the 100 BEST. The ?'s in the Deficiency Column indicate that these are tentative ratings, subject to change upon further trial. It takes at least a two or three year test to determine definitely the merit of a glad, but our catalog would lose much of its value if we waited that long to report on varieties. All our tentative ratings have been corroborated by correspondence with several other fanciers. I do not expect anyone to plunge a great deal of money on the strength of any of these tentative recommendations, tho I do feel that these recommendations are fairly safe.

Some glads have been selected from each color class for inclusion in the First Hundred or Super Glad group. If you do not care for some colors, or dislike Prims, they are not in the First Hundred for you. Every fan should select his own First Hundred. The 100 Super Glads in our list do not exactly suit my personal taste-perhaps 90 of them would-but they represent what I have found by correspondence and other means to be what the consensus of expert opinion considers the leading varieties of today.

Tastes vary-and it is a happy fact that they do. But tastes correspond far more than they vary. And it is that fact which I believe gives our catalog value.

I shall be happy to correspond any time with glad fans on any aspect of our mutual hobby. A frank expression of your reaction to our catalog will be appreciated. Now that all the data about so many hundreds of varieties has been boiled down to a comparatively few pages, there is little evidence of the tremendous amount of work involved in gathering and assembling it. However, it may not yet be $100 \%$ accurate and any correction or suggestion for its improvement that can be passed on to us will be genuinely welcomed. We are planning an album of illustrations for the catalog next year and will be glad to ineorporate other features: that the fans may desire, wherever feasible.

I might add in closing, that if you find our catalog valuable, tell your glad friends about it.

Also-save your catalogs! It should prove interesting years hence - in 1942 and 1952 - to look back through them and observe the procession of great beauties that came at the beck of patient hybridizers, gladdened the hearts of thousands and millions of flower-lovers for a periorl of years and then passed into oblivion to make room for even finer, newer things ever moving in from the bright future land. 


\section{CLASS 1-DARK RED VARIETIES}

SUPER GLADS $\quad \begin{aligned} & \text { (Heavy } \\ & \text { Capitals) }\end{aligned}$ GROUP A GLADS $\underset{\text { Capitals) }}{\text { (Light }}$ GROUP B GLADS $\underset{\text { Type) }}{\text { (Regular }}$

BLACK MAROONS AND MAROONS

\begin{tabular}{|c|c|c|c|c|c|c|c|c|}
\hline Originator & Year & Size & Substance & variety & Price & Type & Season & Deficiencies \\
\hline Hinkle & .1922 & $\mathrm{E}$ & $\mathrm{B}$ & Arabia & .05 & Pl. & $\mathrm{M}$ & $5,7,13$. \\
\hline Prestgard & 1930 & $\mathrm{E}$ & $\mathrm{B}$ & Dark Eye & .35 & $\mathrm{Pl}$. & $\mathrm{M}$ & 18. \\
\hline Hoeg & 1925 & $\mathrm{E}$ & $\mathrm{B}$ & GETTYSBBURG* & .10 & Pl. & M. & 21,23 \\
\hline Pfitzer .... & .1921 & $\mathrm{E}$ & $\mathrm{C}$ & Heinrich Kanzleiter & .20 & $\mathrm{Pl}$. & EMI & 5,6 . \\
\hline Diener & .1925 & $\mathrm{E}$ & B & Imp. Queen of Night & .08 & Pl. &. $\mathrm{M}$ & 21 . \\
\hline Kunderd & .1930 & E & B & MONNIE* & .60 & Pl. & MI & 21. \\
\hline Prestgard & .1928 & $\mathrm{E}$ & $\mathrm{B}$ & MONTENEGRO* & .16 & $\mathrm{Pl}$. & II & 13. \\
\hline Pfitzer .... & .1929 & EEE & A & MOORISH KING & 4.00 & $\mathrm{Pl}$. & $\mathrm{ML}$ & 23 . \\
\hline Pfitzer .... & 1928 & $\mathrm{EE}$ & $\mathrm{B}$ & MOROCCO & .40 & Pl. & ... EM.... & $10 \ldots$ \\
\hline Errey & .1921 & $\mathrm{EE}$ & $\mathrm{C}$ & NIMROD* & .10 & Pl. & M. & \\
\hline Kunderd & .1917 & $\mathrm{EE}$ & B & Rajah & .15 & $\mathrm{Pl}$. & M. & 7,21 \\
\hline Kunderd & .1927 & $\mathrm{E}$ & B & THOMAS A. EDISON (K) & 1.00 & Ruf. & EM. & 5,21 \\
\hline
\end{tabular}

\section{CLASS 2-RED VARIETIES}

RED SELF-COLORS OR NEAR SELFS.

\begin{tabular}{|c|c|c|}
\hline Fallu & 1929 & $\mathrm{EE}$ \\
\hline Kunderd & 1925 & $\mathrm{E}$ \\
\hline Kunderd & 1924 & $\mathrm{E}$ \\
\hline Pfitzer & .1929 & EEE \\
\hline Betscher & .1916 & $\mathrm{EE}$ \\
\hline Salbach & 1929 & $\mathrm{E}$ \\
\hline Alkemade & 1922 & EE \\
\hline Kunderd. & 1915 & $\mathrm{E}$ \\
\hline Kunderd & 1918 & $\mathrm{E}$ \\
\hline Purple & 1926 & EE \\
\hline Kunderd & 1922 & $\mathrm{E}$ \\
\hline Ellis-Piper & 1926 & $\mathrm{EE}$ \\
\hline Kunderd & .1928 & $\mathrm{EE}$ \\
\hline Ellis ........ & .1926 & $\mathrm{E}$ \\
\hline Prestgard & .1929 & $\mathrm{E}$ \\
\hline Lemoine & .1906 & $\mathrm{EE}$ \\
\hline Groff & .1915 & $\mathrm{EE}$ \\
\hline
\end{tabular}

BILL SOWDEN:

Bobby*

Cardinal Prince

COMMANDER KOEHL*

CRIMSON GLOW**............

Diablo*

Illuminator

Joe Coleman

Lustre

$\mathrm{OH}$ BOY

RED FIRE**

\section{RED GLORY}

RED SPLENDOR

Red Tornado

ROALD AMUNDSEN**

ROUGET DE LISLE

Scarlet Wonder**

1.50
.08
.07
1.00
.05
.20
.07
.08
.15
1.00
.05
.20
.40
.35
.25
.20
.05

$\mathrm{Pl}$.

Pl.

Pl.

$\mathrm{Pl}$.

$\mathrm{Pl}$.

Pl.

Pl.

$\mathrm{Pl}$.

$\mathrm{Pl}$.

Pl.

Ruf.

Ruf.

$\mathrm{Pl}$.

Ruf.

$\mathrm{Pl}$.

Pl.

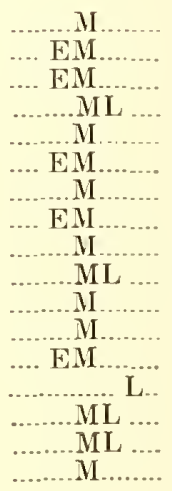

7.

22

5

$3 \ldots \ldots$

3 .

19

$24 \ldots$

$19 \ldots \ldots$

$19 \ldots \ldots$

$23 \ldots \ldots$

7

REDS WITH WHITE OR CREAM THROATS

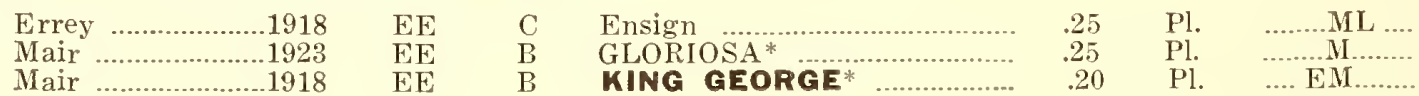

\section{Complete Key to Deficiencies}

kating subjeet to change upon further trial.

Sometimes Alecks

Lacks purity of color.

Throat marking not ideal.

Fades,

Burns in hot weather. (Bloom indoors.)

Ilay crook in hot weather.

Prodnces short flower heads in flry sensons, (Irrivite.)

Weak stem: my lop over in tield.

Sometimes conses opposite-floweref.

Florets sometimes urow iromel stem.

sometimes shoms stem between rows of florer.

Flores sometimas fice moward.

Florets not wirlely apen.

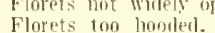

Florets tinther crowiled.

Florets rinther erowiled.

Florists too loosely attactred to stem.

Irrelined to be flopps.

Opens only two or three florets at a time.

19. Variable. (Give sood rulture.)

20. Produces small percentage of representatise blooms.

21. Plant below atverage leeight, (Nut necessirily a fault.)

Does not bloom ont well in witer.

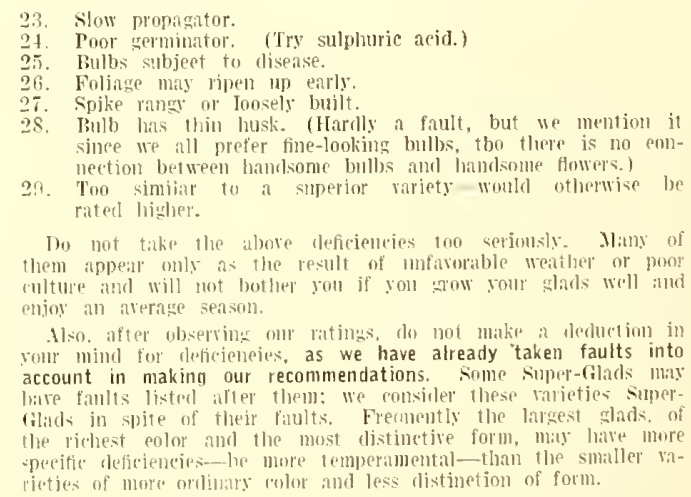




\section{Description of Dark Red Varieties}

The Dark Rerl color division brings us sone of the richest and most popular varieties in the gladiolus world, and certainly no other branch of the floral kingdom can surpass the display of rich, glossy. maroons and "blacks" which the gladiolus offers.

Altho still weak in point of numbers, the Dark Red class probably holds its own today in quality. Certainly Moorish $\mathrm{King}$ and Thomas $A$. Edison are two of the finest glads thus far produced. The former is the more impressive, building a substantial spike, with florets possessing an extremely heavy gloss. Thomas Edison, tho not as robust as Moorish $k i n g$, has the distinction of possessing some of the finest ruffling ever seen in a glad.

Morocco has the merit of being even darkel than Moorish King but otherwise is not quite as fine a flower.

Gettyshurg is probably our next choice. It has been a very consistent producer of good spikes with wide-open florets.

Like nearly all the maroons, Monnie has a fine theen. Heinrich hanzleiter has a more willowy ipike than others in this class.

Dark Eye offers something new in color. Imagine a pure spectrum red, plus $20^{\prime}$ ' yellow, plus $20^{\circ}$ ' black, and you have the deep, velvety, bricky red of Iarli Eyc. A few florets of this variety made up into a corsage to wear with a black velvet costume is richer than a bouquet of red roses. Stock of this beautiful variety is very scarce.

Arabia. long known as the "black glad," has bud: of a glistening jet.

Nontenegro might be described as an enlarged edition of the preceding.

What is our darkest glad? It would be hard to say unless we could have them all together at one time. Perhaps Morocco, Montenegro, or Arabia.

\section{Description of Red Varieties}

While there are a great many glads which fall into the Red class, a careful examination discloses few which can be called really outstanding, and of these few, all save King George are darker than true spectrum red. The best of the light reds seems to be Roald Amundson.

Bill Sowden is an impressive, heavy-petaled glad of a sober, deep-red hue. Its round florets are more widely opened than is the case with Purple Glory. In a symposium conducted in Australia, this varicty tied with five others for first place as the best native origination.

Bobby is a good all-around red with a large dark throat. Cardinal Prince has a fine silky texture. It is practically a self of a rather light hue.

In Commander Koehl Pfitzer has given us one of his best-a glad deep-toned, rich, and heavy-textured. Its rather narrow petals give it plenty of style and individuality, as well as suggesting a relationship to Hoorish King.

Crimson Glow is the old standby in the red class. Illuminator is another old favorite, which when well grown is overcast by an almost sky-blue sheen. It is curious how some of the finest features, as developed by the hybridizer's art, may drop away from a glarl when it is poorly grown. Sheen, richness or purity of color, even luffing, may entirely llisappear, leaving a very ordinary looking flower. Culture is still half the trick of growing fine flowers.

(Oh Boy is a griant scarlet-red, about as near a self as a glad ever comes. An improved Scurlet Honder.

Next we come to four of Mr. Kunderd's: Joe Coleman, a reliable rufflerl sort with excellent place- ment; Lustre, notable for its fine translucent sheen; Pythia, a massive light sort with heavy midribs; and, finest of them all, Red Fire, which we were tempted to put into the first hundred on account of its flashing, fiery color-quite the best of all the reds. But, since it can harlly be called a "super-glad" in other respects, we felt obliged to leave it out.

Red Glory is a crimson sport of Purple Glory, and hence naturally a mighty tine glad. This variety looks especially rich under artificial light.

Red Splendor shows a kinship to the preceding, probably being a seedling of Iurple Glory.

Red Tornado came close to being a great glad, but has proved erratic. Velvety scarlet-red with a large dark blotch.

Roald Amundsen is a strong growing sort that remincls one of $I) r . F$. E. Bennett. It lacks, however, the touch of yellow in its make-up needed to constitute a true scarlet. It is also slightly smaller than Berrutt and much more heavily ruffled. Substance is extremely heary-the heaviest of all the reds.

Rouget De Iisle deserves to be better known. It is a steady performer, but variable in color. The large throat blotch, rimmed with a white sanding. may be anything from crimson to purple, in the latter case prolucing a rather garish effect.

scarlet Wonder, otherwise known as Majestic or "Lost $R e d$ ", was the sensation of fifteen year": ago. A giant at its best.

Ensign, King George, and Gloriosa are all very similar, except that King George has a cream-colored blotch instead of a white one. With further testing floriosa may piove the best of the three. 


\section{CLASS 3-SCARLETS}

\section{SUPER GLADS (Heary}

\author{
GROUP A GLADS $\underset{\text { Capitals) }}{\text { (right }}$
}

GROUP B GLADS $\underset{\text { Type) }}{\text { (Regular }}$

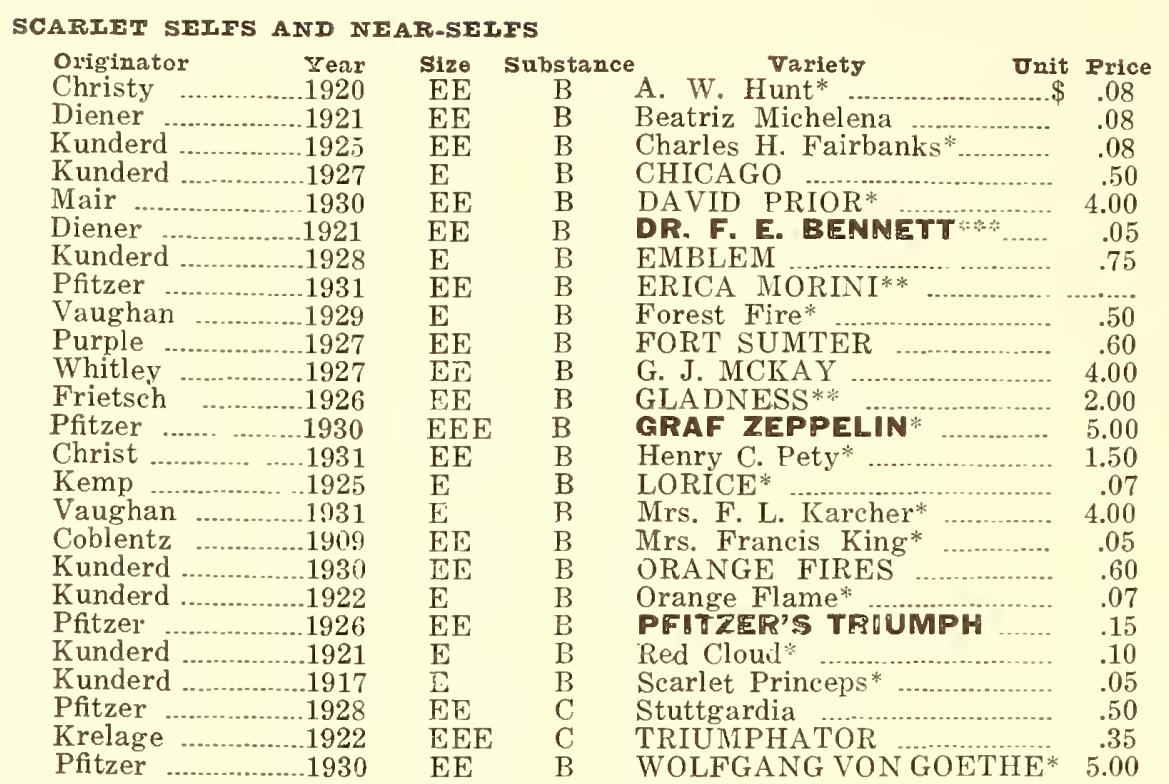

SCARIETS WITII WIITE THPOATS

\begin{tabular}{|c|c|c|}
\hline Ellis & 1930 & $\mathrm{EE}$ \\
\hline Mair & .1921 & $\mathrm{EE}$ \\
\hline Ellis & .......................... & $\mathrm{EE}$ \\
\hline Ellis & .1926 & $\mathrm{EE}$ \\
\hline Errey & .1919 & $\mathbf{E}$ \\
\hline Pfitze & .1930 & 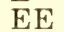 \\
\hline
\end{tabular}

Pfitzer $\quad 1930 \quad$ EF

PRIMUIINOS GRANDIFIORUS

Salbach ...............1925 E

Neeley ...................1929

$\begin{array}{ll}\text { EEE } & B \\ \mathrm{E} & \mathrm{B} \\ \mathrm{EE} & \mathrm{B}\end{array}$

COMMODORE**

Duchess of Atholl

Lady Macbeth*

PRIDE OF PORTE,AND $\quad .40$

WUERTEMBERGHA***..... 6.00

AFLAME*:

Scarlet Bedder*

SUNSHINE GLOW*

.15

.20

Type
Pl.
Pl.
Pl.
Ruf.
Pl.
Ruf.
Pl.
Pl.
Pl.
Pl.
Ruf.
Pl.
Pl.
Pl.
Pl.
Pl.
Pl.
Ruf.
Ruf.
Pl.
Pl.
Pl.
Pl.
Pl.
Pl.

Pl.

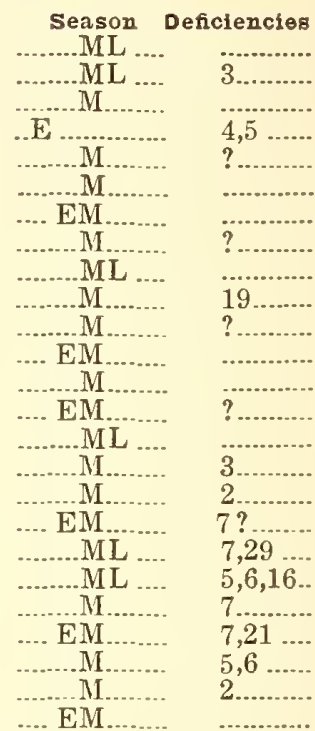

Pl.

Pl.

Pl.

Pl.

29 29.

5 $19 \ldots \ldots$

Pl.

Pl.

Pl.

\section{CLASS 4-ORANGES}

\section{ORANGES OF AII SHADES}

Kirchhoff $\ldots$..............1927
Vaughan

$\begin{array}{ll}\text { EE } & \text { B } \\ \text { EEE } & B \\ \text { EE } & B \\ \text { E } & B \\ \text { EE } & \text { B } \\ \text { E } & \text { B } \\ \text { EEE } & \text { B } \\ \text { E } & \text { B } \\ \text { EE } & \text { B } \\ \text { E } & \text { B } \\ \text { EE } & \text { B }\end{array}$

\section{PRIMUIINUS GRANDIRLORUS}

Fischer

Kunderd ................1928

Dusinberre 1929

Prestgard .............1929

Salbach $\quad 1925$

Pfitzer ..................1919

Austin ..................... 1928

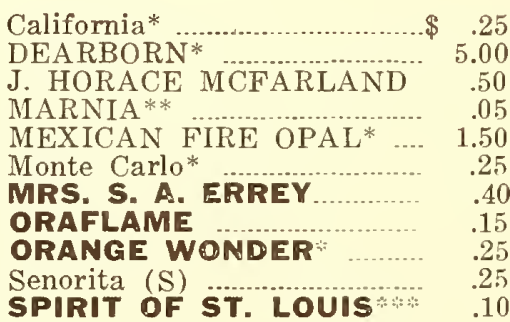

ETHELYN*

GAY HUSSAR

KING OF ORANGES

LA PALOMA

Mandarin**

Nancy Hanks*

ORANGE QUEEN***

RADIANT ORANGE*
$\mathrm{Pl}$.
$\mathrm{Pl}$.
$\mathrm{Pl}$.
$\mathrm{Pl}$.
$\mathrm{Pl}$.
$\mathrm{Pl}$
$\mathrm{Pl}$
$\mathrm{Pl}$
$\mathrm{Pl}$
$\mathrm{Pl}$
$\mathrm{Pl}$

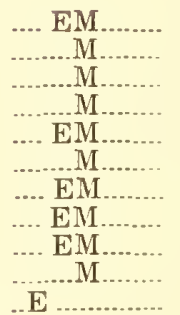

3

$7 \ldots \ldots \ldots$

21.

$15 \ldots . . .$.

$7 \ldots \ldots$

$21 \ldots .$.

21

15
Pl.
Pl.
Pl.
Pl.
Pl.
Pl.
Pl.
Pl.

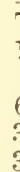
17 6. 3. 


\section{Description of Scarlets}

Scarlet brings us to one of the strongest color classes in the gladiolus world.

Our first choice here, provided we were confilled to a single variety, would be Dr. F. E. Bennett. Considering both beauty and performance, we believe this to be one of the ten best glads. Very vivid color. In spite of the drought last summer, Bennett averaged 18 to 20 buds per spike and we saw a spike at the Minnesota State Show with nine perfect florets open at one time.

The only scarlet that can definitely surpass $D$ r $F$. E. Bemett in beauty is I'fitzer's 'Triumph, but it must be well growll. In rich sparkling, velvety texture this glad is unsurpassed. Erica Morini has been described as an improved Triumph, and, while it is true that it opens twice as many florets at one time, they are of the silky, reflexed type which makes the two varieties hardly comparable. Another fine one from Pfitzer is Graf Zeppelin, an enormous rich scarlet self, very impressive as a show flower. Wolfgang Von Goethe is practically its equal, but just a shade less vivid. Both these glads are of a silky texture and without any marked distinctiveness of form. Stuttgardia is a great glad in cool climates, but is not worth much in mid-continental $N$. America. It is a warm, rich, light scarlet.

Two of Kunderd's best are chicago and Orange Fires. The former is a truly aristocratic beauty but strictly a fancier's flower. To its very rich salmon-vermilion color (a shade lighter than Pfitzer"s Triumph) is added a spendid ruffling. Petals are sometimes edged a steely blue. Orange Fires possesses almost "A" substance and was a candirlate for the Super Glad class. True scarlet with spirlery white throat markings. Large, flat blooms and extremely heavy ruffing. . . Lesser Kunderd beauties are Charles H. Fairbanks, a fine clear scarlet, with slight ruffling; Emblem, unique for its enormous blotch on all petals, rimmed with a conspicuous light sanding; Red (Joud, a Kunderd version of $I M$. Bennet; Orange Flame, a smaller, ruffled Triumph; ansl Scrilet Princeps, the progenitor of many of to-day's winners in this color class.

Lorice and Mrs. Francis I. Karcher are valuable for their unique color - a cross between scarlet and orange.

A coming beauty is G. J. Mckiay, accurately described as a rich tomato red, heavily ruffled. Florets are round and slightly recurved.

Other scarlets that are still worth-while are Triumphator, a giant with heavy flecking; Mrs. Francis King. a great glad of yesterday and still good, tho its color looks dull when you put it alongside of Bennett; Gladness, a little-known sort which ap-

\section{Description of Oranges}

Orauge has proved an elusive color to the hybridist, and it is only by padding with the orangeyellows and salmon-oranges that a respectable orange color class can be contrived.

Spirit of St. Louis, a comparative newcomer, seems to be about the best all-around performer in the grandiflorus type. It is of a subdued shade, but otherwise approximates true orange. Its six to eight leathery-textured florets will not show a sign of drooping until the thermometer passes $95^{\circ}$ in the shade.

Mrs. Errey is sort of a blood-orange, with darksive when well grown. proaches (iruf Zeppelin in appearance and quality: Fort Sumter, a massive deep scarlet self of the heaviest silky texture; and David Prior. scarlet to a yellow throat. A. W. Hunt stands half-way between Bennett and Pfitzer"s Triumph, but is less rich than either. Beatriz Michelena--too bad that a wonderful flower was not given this beautiful name. Forest Fire-notable for its large, lark throat. Henry C. Pety-a massive spike of fiery scarlet with a small, sharp throat marking of ruby, tipped white.

The scarlets with white throats have showl tremendous advancement since the days of Princeps (Van Fleet, 1893), the variety to which all the winners in this group today could probably trace their ancestry.

The Ellises have given us several of our best. Pride of Portland is hard to classify as to color-a scarlet so light as often to seem a deep pink; hence unique. A large and showy flower that opens quite flat, but not a glad that will stand rough handling. This variety has given us some magnificent spikes. Commodore is just the reverse of Moulam MounetSully. A fine, robust variety that stands heat remarkably wel!. . . Iady Macbeth -a less recurved Commorlore.

Victor is more velvety and opaque than silky and translucent, like other's in this class. The small snow-white blotch, sharply contrasted with the deep scarlet petals, looks marvelously pure.

Wuertembergia is a new giant just coming to the fore. While it has not opened more than foul florets for us, they are of such tremendous size as almost to put it into the triple "E" class. Color is a light scarlet of a rich and silky texture, blotch is small, and the midribs quite heavy, conferring plenty of distinction of form.

Duchess of Atholl is a fine sort with smaller florets and more open. Silky texture.

Iflame-one of the largest glads in existence. Very outstanding at every show. Fair color and a spike that shoots up like a small tree. Can be grown nearly six feet tall with winged florets nearly seven inchs across. Grow this in quantity if you want to impress your neighbors.

Scarlet Bedder-silky scarlet self; good.

Sunshine filow - a large glad with about five florets open at one time. The midribs of the lower petals are so long that they extend out beyond the petals themselves, producing the effect of several giant red swallowtail butterflies gracefully poised upon the thin wiry stem. Radiant color, fine cream throat.

el throat. Strictly a cool weather glad. Impres-

Kemp has given us several of our finest oranges, all of them seedlings of Golden Measure. Marnia is probably the best low-priced commercial. It has a touch of salmon flecking in its make-up. Orange Wonder is very rich and velvety, a solid salmon-orange way into the throat. Oraflame is a light true orange, blending to a pure yellow throat.

J. Horace McFarland is of a fine old gold color. (Continued on page 31.) 


\section{CLASS 5-YELLOWS}

\begin{tabular}{|c|c|c|c|c|c|c|c|c|}
\hline \multirow{3}{*}{\multicolumn{3}{|c|}{$\begin{array}{l}\text { SUPER GLADS ( } \begin{array}{c}\text { Meavy } \\
\text { Capitals) }\end{array} \\
\text { YELLOW SELFS AND NEAR-SELF } \\
\text { Orioinator }\end{array}$}} & \multirow{2}{*}{\multicolumn{2}{|c|}{ GROUP A GLADS $\underbrace{\text { (Light }}_{\text {Capitals) }}$}} & \multicolumn{2}{|c|}{ GROUP } & B GLADS & $\begin{array}{l}\text { (Regular } \\
\text { Type) }\end{array}$ \\
\hline & & & & & & & & \\
\hline & & & $\begin{array}{c}\text { substance } \\
B\end{array}$ & $\begin{array}{l}\text { e } \\
\text { Bariety } \\
\text { Beauty Wave ... }\end{array}$ & $\begin{array}{c}\text { Price } \\
.25\end{array}$ & $\begin{array}{l}\text { Type } \\
\text { Ruf. }\end{array}$ & Season & Deficiencies \\
\hline Vaughan & 1929 & $\mathrm{EE}$ & B & CADILLAC & 2.00 & Pl. & .... EM ...... & \\
\hline Errey. & 1927 & $\mathrm{EE}$ & B & CANBERRA & .50 & $\mathrm{Pl}$. & … CMt. & \\
\hline & 1931 & $\mathrm{EE}$ & $\mathrm{C}$ & DR. DURR* . & & Pl. & E & \\
\hline $\mathrm{H}$ & 19 & $\mathrm{E}$ & C & Gold $\ldots . . .$. & .07 & Pl. & .... EM. & 5,7 \\
\hline & 19 & $\mathrm{E}$ & $\mathrm{C}$ & Gold Eagle* & .05 & Pl. & E. & \\
\hline & 1929 & $\mathrm{E}$ & $\mathrm{C}$ & GOLDEN CHIMES* & 7.50 & Pl. & .... EM & \\
\hline & .1923 & $\mathrm{E}$ & B & GOLDEN DREAM & .05 & Pl. & ...ML & \\
\hline c & .1929 & $\mathrm{E}$ & $\mathrm{B}$ & GOLDEN GLOW* & .50 & Pl. & M & \\
\hline & 1908 & $\mathrm{E}$ & $\mathrm{B}$ & GOLDEN MEASU & .05 & Pl. & ..........ML & \\
\hline & .1927 & $\mathrm{E}$ & $P$ & Heliosa ............... & 2.00 & Ruf. & $\ldots$ & 6,23 \\
\hline & .1927 & $\mathrm{E}$ & a & w Favo & .05 & Pl. & EM & \\
\hline & .1928 & $\mathrm{E}$ & B & LOY & .35 & Pl. & ..... & \\
\hline $\mathrm{K}$ & .1930 & $\mathrm{EE}$ & $\mathrm{C}$ & Mrs. E. A. Hamill & 1.00 & Pl. & M & \\
\hline & & $\mathrm{E}$ & $C$ & New Gold & 2.00 & Pl. & …... I. & \\
\hline & 19 & $\mathrm{EE}$ & $\mathrm{C}$ & & .10 & Pl. & $\mathrm{M}$ & \\
\hline & .19 & $\mathrm{E}$ & $\mathrm{C}$ & NCESS* & .10 & Pl. & …......I. & \\
\hline & 19 & $\mathrm{E}$ & $\mathrm{B}$ & 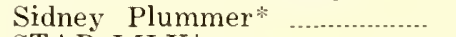 & .10 & Pl. & & \\
\hline & 1929 & $\mathrm{EE}$ & B & & .35 & Ruf. & $\ldots \mathrm{M}$ & \\
\hline & .1929 & $\mathrm{E}$ & B & Th & 1.00 & & $\ldots . . . . .$. & 7,29 \\
\hline & 1928 & 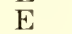 & - & & .50 & $\mathrm{P}$ & .......ML & \\
\hline Pfitzer & 19 & $\mathrm{E}$ & c & YELLC & .60 & Pl. & $M$ & \\
\hline Pfitzer & 1926 & $\mathrm{E}$ & $\mathrm{C}$ & V WONDEF & .60 & Pl. & ML & \\
\hline Gelser. & 1929 & $\mathrm{E}$ & $\mathrm{C}$ & Wyoming & .15 & Pl. & EMI... & \\
\hline \multicolumn{9}{|c|}{ YELLOWS WITH PRONOUNCED THROAT BTOTCHES } \\
\hline & .1929 & $\mathrm{EE}$ & B & GOLDEN ANN & 1.50 & & ........ & \\
\hline Kunderd & 1930 & $\mathrm{E}$ & B & LUXURY & .75 & & -........M & 21 \\
\hline \multicolumn{9}{|c|}{ PRIMUIINUS GRANDIFLORUS } \\
\hline & & $\mathrm{E}$ & $\mathrm{B}$ & E. & .25 & & El & \\
\hline & & E & $\mathrm{C}$ & & 1.00 & & ENI. & \\
\hline & 1929 & 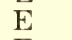 & 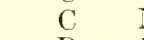 & & 2.50 & $\mathrm{P}$ & .... EM & \\
\hline & 1929 & $\mathrm{E}$ & B & & .20 & & …II & \\
\hline & .19 & $\mathrm{~F}$ & & & .20 & $\mathrm{D}$ & & \\
\hline Palmer & .1931 & $\mathrm{E}$ & B & SPR & 2.00 & Pl. & E. & \\
\hline
\end{tabular}

\section{CLASS 6-CREAM, BUFF, and FLESH VARIETIES}

CREAM

\begin{tabular}{|c|c|c|c|c|}
\hline & & & & \\
\hline Graetz & $\mathrm{EE}$ & $\mathrm{C}$ & 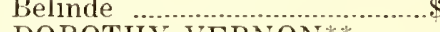 & \\
\hline Hoeg ...... & $\mathrm{E}$ & $\mathrm{B}$ & DOROTHY VERNON** & \\
\hline Kunderd .... & $\mathrm{EE}$ & $\mathrm{C}$ & FERN KYLE .... & \\
\hline Salbach : & $\mathrm{E}$ & $\mathrm{B}$ & Idamae ${ }^{* *}$ & \\
\hline Stevens, H. W...... 1931 & $\mathrm{EE}$ & $\mathrm{B}$ & MARY ELIZABETH & 15. \\
\hline Errey ...................... & $\mathrm{EE}$ & $\mathrm{C}$ & MELISSA & \\
\hline Pfitzer ............ & $\mathrm{EE}$ & $\mathrm{C}$ & MRS. ANNA PFITZER & \\
\hline Miller, D. R...... 1930 & $\mathrm{EE}$ & $\mathrm{C}$ & MRS. RAY P. CHASE ... & 5.0 \\
\hline Van Deursen .....1920 & $\mathrm{EE}$ & $\mathrm{C}$ & Obelisque .......... & 2.00 \\
\hline Kirchhoff .............. 1926 & $\mathrm{E}$ & $\mathrm{B}$ & SHASTA * & \\
\hline JFE & & & & \\
\hline Austin & $\mathrm{E}$ & B & Helen Howard * & \\
\hline Crow .................... 1930 & $\mathrm{EE}$ & A & HERCULES** & 25.0 \\
\hline Prestgard ............1928 & $\mathrm{EE}$ & $\mathrm{B}$ & Madam Norena & \\
\hline Kunderd ...... & $\mathrm{E}$ & $\mathrm{B}$ & Ne Plus Ultra .. & \\
\hline Prestgard ...........1925 & $\mathrm{E}$ & $\mathrm{B}$ & Trilby* $\ldots$ & \\
\hline Kunderd ...............1921 & $\mathrm{E}$ & $\mathrm{B}$ & Twilight** & \\
\hline SW & & & & \\
\hline Pety & $\mathrm{E}$ & $\mathrm{B}$ & Amity & \\
\hline Kunderd ........... 1931 & $\mathrm{E}$ & $\mathrm{C}$ & Anna Mae & .5 \\
\hline Kunderd ............1918 & $\mathrm{E}$ & $\mathrm{B}$ & Anthony B. Kunderd* & \\
\hline Kunderd ...............1931 & $\mathrm{E}$ & $\mathrm{C}$ & CREAM CUPS & .50 \\
\hline 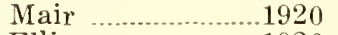 & $\mathrm{EE}$ & $\mathrm{B}$ & QUEEN MARY & 1.00 \\
\hline Ellis ............ 1926 & $\mathrm{EE}$ & $\mathrm{C}$ & Rippling Waters & .2 \\
\hline Diener ....................1917 & $\mathrm{EE}$ & $\mathrm{B}$ & WM. KENT ........ & \\
\hline WITH PRON & & & OT & \\
\hline דזר חת הזידו & $\mathrm{FT}$ & B & nne & \\
\hline IIVUIINUS GRANDI & & & & \\
\hline Vaughan .............1930 & $\mathrm{E}$ & $\mathrm{C}$ & BIJOU & .50 \\
\hline Palmer ......... & EE & $\mathrm{C}$ & FLOSELLA * & 1.50 \\
\hline Kunderd ...... & $\mathrm{E}$ & $\mathrm{C}$ & Ming Toy* ... & o \\
\hline
\end{tabular}

Pl.

Pl.

Ruf

Pl.

Ruf.

$\mathrm{Pl}$.

Ruf.

$\mathrm{Pl}$.

$\mathrm{Pl}$.

Ruf.

Pl.

Pl.

Ruf.

Ruf.

Ruf.

Ruf.

Ruf.

Pl.

Ruf.

Pl.

Ru

Ruf.

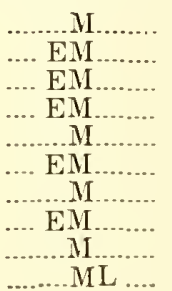

5 ,

$5,21,2$

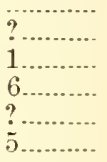

$1 \ldots$

$6 ?$

t...........

$3,7 \ldots \ldots$

$21 \ldots \ldots . .$. 29.

$2,7 \ldots$.

$19,23$.

7 .......

19.

Pl. ... E ......

Ruf. .... EM

$\mathrm{Pl}$.

$\mathrm{Pl}$.
E

For Key ta Deficiencies, see page 10 . 


\section{Description of Yellows}

Altho there are no yellow glads today of the size and quality of some of our best in other color classes, I believe we shall not have to wait many years for something really outstanding to appear in this color group. In the meantime we may enjoy several varieties which are very beautiful, tho they may leave something to be desired in size and depth of hue.

Our favorite still is Golden Iream. This glad will open up about six four-inch florets at one time. Color is not far from the deepest yet achieved and unusually clear; texture leathery. Florets are strongly recurved, making it the most pronounced example we have of the rosebud type. A really. lavish bouquet of this variety vased in soft green or lavender pottery is something long to be remembered. Fans who a few years ago were proud to have a half-dozen Colden Uroum in their gardens, can now enjoy the long-anticipated luxury of growing it in generous cutting quantity.

Another excellent sort that is growing in popularity, is Tobersun. Rich color and a fairly compact spike. Loyalty and The frand Guardian are similar, but do not have the suggestion of needlepoint form that characterizes Tobersur.

Canberra is sometimes referred to as an improved folden Measure. The same may be said of Golden Glow. These glads tend to be larger than Folden liream, but not quite so fine ol deep in colol. .... The largest yellow to clate is probably Cadillac, a rich deep yellow with just a hint of apricot about the tips. This glad sometimes comes with splendid precision of form, but at other times it is rather loosely built.

We remember Star Lily with pleasure on account of its crisp, well-spaced, nicely ruffled florets. Color light, substance very heavy, spike unusually long. Florets wide-open and somewhat star-shaped. An improved Heliosa.

Yellow I'erfection and Yellow Wonder are two soft, silky yellows that make fine spikes. The former is rather the better of the two. Dr. Durr is a fine, large, light yellow sort that looks very promising.

Data on the left-hand page throughout this section of our catalog is so comprehensive that un- less a glad has lots of personality, there is not much to ald in the way of description. Generally speaking, the yellow glads are not so sharply differentiated from each other as is the case with varieties in most other color classes.

Other yellows of interest are: Norma Talmadge. which can make a spike as massive as IV. H. Phipps, but generally comes short; I'rimrose P'rincess, a reliable light sort with a few faint carmine markings deep in the throat. Similar markings may be noted in Kunderd's Yellow Favorite. Mrs. F. A. Hamill-a smaller Cudillac. Other Kunderd yellows, tho beautiful, have been omitted from our list on account of their low heat resistance.

Golden Anniversary-a stalwart glael with quite a bit of individuality. Light yellow with a small round throat bloteh. luxury-well deseribed by Mr. Kunderd as being rich as a pansy. Velvety canary yellow with small scarlet throat blotches that are clear and rich. Something different.

E. I. Farrirgton-a Prestgard origination of which the late Louis Rowe, one of the best judges of glads in the country, purchased the entire stock. In precision of placement and heaviness of ruffling, it might be called a yellow Crinliles, but the spike is much longer. The best ruffled commercial yellow; in fact, about the only one.

Mr. Crow has given us several fine yellows, all of good growth and rather similar in appearance. We like Primate the best. The color is just a trifle lighter than the Empire Yellow of Golden I reen, florets are larger, but fewer are open at once. Irimate is tall and apparently always comes straight, reminding one of Miss .Joy in its ideal cutting qualities.

We consider IRuftled Gold a highly artistic flower. There are a great many styles of ruffling and this glad has one of the finest. There is real distinction, too, in the rose throat mark cut off so abruptly before it has fairly begun to be a blotch.

spray of frold is a finer, larger Sourenir.

\section{Description of Cream, Buff, and Flesh Varieties}

It has always seemed to me that the white and yellow combination was one of the most beautifui conceivable in a gladiolus. Nothing else will mix so readily with other colors in a bouquet. It was always something to be looked forward to-the coming of a really fine glarl to take the place of the old Mary Pickford. Mary Elizaheth seems to be the one. Pure white with a rich yellow throat. Fine, opaque, waxy substance. Beautiful ruffling. If the performance of this glarl equals its beauty, it has an enviable future. . . Until Mary Elizabeth gets down in price, its best low priced substitute is probably Worothy Vernon. Mrs. Ray P. Chase is also very similar a glad of lovely warm coloring. Florets are round, well-opened, and neatly placed. We prefer it to Mrs. Anna I'fitzer, a translucent pale cream sort.

Melissa-most variable of glads. Its solicl, deep cream color can come so heavily flecked with rose-red that one would never recognize the variety. ... Belinde and Obelisque are extremely pale yellows, very silky in texture. Shasta-a fine waxy sort, almost a white. Fern liyle can be very chastely beautiful when well grown, but nothing looks more miserable when persecuted by the elements.

Among the buffs, Ilercules is most imposing. Its tawney sharle reminds one of "pinochio" candy or brown sugar. Florets are extremely heavy, very plain as to form, and set well apart on the heav? stem. Vielen Howard - a vellow Molissu. Tribyan exceptionally heavily ruffled deep tan glad. Twilight and Ne p'lus Ultra have a small red throat feather. 'The latter has al fine, crisp luffling anci florets which are set well apart. IIadam Norenaapricot with a golrlen throat.

Queen Mary-One of the biggest thrills of the National show last year was the vase of this clisplayed by Bancroft Winsor. A typical fancier"s flower that wants more than ordinary culture. Pale creamy-flesh with many medium-sized florets open at one time. Wavy rufling of an almost crystalline (Continued on page 31.) 


\section{CLASS 7-WHITES}

SUPER GLADS $\underset{\substack{\text { (Heavy } \\ \text { Capitals) }}}{\text { STl }}$

GROUP A GLADS $\underset{\text { Capitals) }}{\text { (Light }}$

GROUP B GLADS (Regular

PURE WHITES AND WHITES WITH INCONSPICUOUS THROAT MARKINGS

\begin{tabular}{|c|c|c|c|c|c|c|c|c|}
\hline $\begin{array}{l}\text { Originator } \\
\text { Kemp }\end{array}$ & $\begin{array}{l}\text { Year } \\
1921\end{array}$ & $\stackrel{\text { Size }}{\mathrm{E}}$ & $\underset{C}{\text { Substance }}$ & Albania* Variety & $\begin{array}{l}\text { Price } \\
.05\end{array}$ & $\begin{array}{c}\text { Type } \\
\text { Pl. }\end{array}$ & $\begin{array}{l}\text { Season } \\
M\end{array}$ & $\begin{array}{r}\text { Deficiencles } \\
\quad 7,21 \ldots\end{array}$ \\
\hline Pfitzer .... & .1927 & EE & $\mathrm{B}$ & ALBATROSS & .50 & $\mathrm{Pl}$. & $M$ & 12.16 \\
\hline Prestgard & 1918 & $\mathrm{E}$ & $\mathrm{C}$ & Carmen Sylva** & .05 & Pl. & ML & \\
\hline Berthoud & 1927 & $\mathrm{EE}$ & $\mathrm{B}$ & GIANT PEARL & 2.00 & Pl. & IM. & \\
\hline Salbach & 1926 & $\mathrm{E}$ & B & Helen Wills* .... & .12 & Pl. & $\mathrm{M}$ & \\
\hline Joerg & 1924 & EEE & $\mathrm{C}$ & JOERG'S WHITE & .10 & Pl. & M. & 3,28 \\
\hline Pfitzer & .1928 & $\mathrm{EEE}$ & B & JONKHEER VAN TETS* & 1.00 & Pl. & .......M. & $10 \ldots$ \\
\hline Pfitzer & .1922 & EEE & B & MAMMOTH WHITE* ....... & .50 & Pl. & ... & 15 . \\
\hline Kunderd & .1918 & $\mathrm{E}$ & $\mathrm{C}$ & MARIE KUNDERD* & .05 & Ruf. & E & 21. \\
\hline Austin & 1929 & $\mathrm{EE}$ & $\mathrm{C}$ & Mary O’Mine & .15 & $\mathrm{Pl}$. & .........M. & 16,17 . \\
\hline Pfitzer & 1925 & $\mathrm{E}$ & $\mathrm{C}$ & Memory of Wm. Pfitzer. & .25 & Pl. & .... EM. & \\
\hline Hornberger & .1925 & $\mathrm{E}$ & $\mathrm{C}$ & MRS. F. C. HORNBERGER* & .05 & $\mathrm{Pl}$. & $\ldots \ldots \ldots \ldots$ & 7,21 . \\
\hline Prestgard & 1925 & $\mathrm{E}$ & B & Mrs. Kr. Prestgard & .10 & Ruf. & M. & 19,23 \\
\hline Pfitzer & 1929 & $\mathrm{E}$ & B & QUEEN LOUISE* & 1.50 & Pl. & ML .... & \\
\hline Kunderd & .1917 & $\mathrm{E}$ & $\mathrm{B}$ & SNOW GLORY & .25 & Ruf. & .... EM.... & 7. \\
\hline Prestgard & 1932 & $\mathrm{EEE}$ & A & SOLVEIG & 50.00 & Ruf. & ............. L.. & \\
\hline Vaughan & 1927 & $\mathrm{EE}$ & $\mathrm{C}$ & VAUGHAN'S WHITE** & .15 & Pl. & .......M.... & 7. \\
\hline Pfitzer & .1926 & $\mathrm{EE}$ & B & WHITE PEARL* ${ }^{*}$ & .20 & Pl. & L. & 23 \\
\hline
\end{tabular}

WHITES WITH PRONOUNCED THROAT BIOTCHES

\begin{tabular}{|c|c|c|}
\hline Briggs & 1926 & $\mathrm{EE}$ \\
\hline Prestgard & 1930 & $\mathrm{EE}$ \\
\hline Fischer & 1919 & $\mathrm{EE}$ \\
\hline Kunderd & 1921 & $\mathrm{E}$ \\
\hline Lemoine. & .1922 & $\mathrm{EE}$ \\
\hline Lemoine & .1908 & EE \\
\hline Stevens, I & .1929 & $\mathrm{EE}$ \\
\hline Lemoine. & 1920 & $\mathrm{EE}$ \\
\hline Groff & 1899 & $\mathrm{EE}$ \\
\hline Leifer & .1929 & $\mathrm{E}$ \\
\hline Kunderd & .1915 & $\mathrm{E}$ \\
\hline Gelser & .1930 & EE \\
\hline
\end{tabular}

CORONADO

EARL BENBOW

HENRY C. GOEHL*

Hollyhock 20

Madam George Boulay*

MADAM MOUNET-SULLY*

MIBLOOM**

ODALISQUE* *...................... $\quad .25$

Peace*

S. A. KURTZ …........................

Snow Boy* $\quad .15$

WHITE KNIGHT** ........... 1.00

Ruf.

Pl.

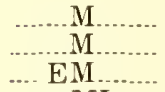

19,21

Ruf.

Pl.

Pl.

Pl.

$\mathrm{Pl}$.

Pl.

......ML ...

.... EM

E.

E.

Ruf.

.......................

Pl. ........ML ...

19,23 .

$7,18,21$

$29 \ldots \ldots$

$10 \ldots . . .$.

19

7

PRIMULIFUS GRAIDIFLORUS

Pfitzer ..............1930 E.E

Vaughan ..............1929

Brown, C. W. ......1924

$\mathrm{E} E$
$\mathrm{E}$
$\mathrm{E}$
$\mathrm{E}$

MAID OF ORLEANS

6.00

Seafoam**

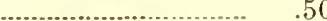

White Orchid** ……............... $\quad .25$

Pl.

Pl.

Ruf.

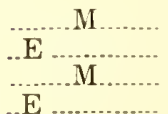

Purple .................1926

\section{CLASS 8-PURE-PINKS}

PURE PINK SELFS AND PURE PINKS WITH WHITE THROATS

\begin{tabular}{|c|c|c|}
\hline Prestgard & ..1926 & $\mathrm{EE}$ \\
\hline Hoeg ...... & .1930 & $\mathrm{EE}$ \\
\hline Swartley & 1928 & $\mathrm{E}$ \\
\hline Briggs .... & 1927 & EE \\
\hline Christ ... & .1930 & $\mathrm{EE}$ \\
\hline Austin & .1929 & $\mathrm{EE}$ \\
\hline Coleman & 1921 & $\mathrm{EE}$ \\
\hline Alkemade & .1927 & $\mathrm{EEE}$ \\
\hline Mair ......... & .1927 & $\mathrm{EEE}$ \\
\hline Errey & ..1925 & $\mathrm{EE}$ \\
\hline Prestgard & .1924 & $\mathrm{E}$ \\
\hline Gage ..... & .1922 & $\mathrm{EE}$ \\
\hline Kingsley & .1926 & $\mathrm{EEE}$ \\
\hline Groff ........ & .1916 & $\mathrm{E}$ \\
\hline Fischer &. .1919 & EE \\
\hline Miller, Mr & . 192 & $\mathrm{EE}$ \\
\hline
\end{tabular}

CHARLES LINDBERGH $\ldots . . \$ 2.00$

DECORATION***

Elizabeth Swartley**

Frank J. MeCoy* .35

FRANZ SCHUBERT …......... $\quad .50$

Gallant Leader*

GIANT NYMPH*⿻丷木

Impressive …........................ 5.00

JESSIE**:

LAIDLEY* …….................. 1.00

LONGFELLOW*

Maurice Fuld .15

PEARL OF CALIFORNIA $\quad .12$

Prosperity***

SOPHIE FISCHER …….... .25

Pl.
Pl.
Pl.
Pl.
Pl.
Pl.
Pl.
Pl.
Pl.
Pl.
Pl.
Pl.
Pl.
Pl.
$\mathrm{Pl}$

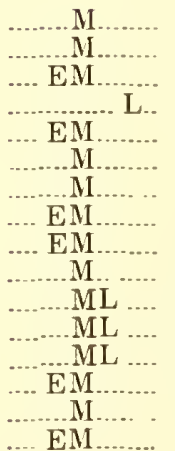

23

10,29

?

17

17.

$1 \ldots \ldots \ldots$

$19 \ldots$

$1,21 \ldots$

$19 \ldots \ldots$

?
PRIMUIINUS GRANDIFIORUS

Kunderd . .1921
B

Shell Pink**

.05

$\mathrm{Pl}$.

.... EM.

For Key to Deficiencies, see page 10. 


\section{Description of Whites}

Our favorite among the many fine whites sent over in recent years from Germany is Jonkheer Van Tets. Its lovely round florets possess a greater opulence of form than any other of Pfitzer's whites. A suggestion of cream in the throat provides the needed touch of warmth. Mammoth White is similar but not $\leqslant$ broad-petaled, tho it may have more florets open at one time. Both these glads have tremendous size. Albatross is a colder beauty, that satisfies the demand for a suow-white glad. Queen Louise might be described as a smaller Jonlilecer Van Tets. White Pearl builds a massive, close-set spike. It has a slight throat marking of rose. Memory of $\mathbf{W m}$. Pfit. zer-a glad of moderate size and great purity of color.

Tho a bit less beautiful than our foreign contributions, Joerg's White seems more reliable in producing fine spikes of a truly giant size. A seedling of two old Pfitzer varieties.

Solveig - a white beyond comparison with any of its predecessors, and we say it without intent to disparage any of our other fine white varieties. Pictures of Solveig give little conception of its majestic size and dazzling, snowy beauty. Its florets are fully as large as those of Pfitzer's Triumph and we have had twice as many open at one time. Substance is superlatively heavy. The extreme wide-open-ness or flatness of the florets is so marked that some experts have pronounced it a distinct break in form. How outstanding this glad is may be judged from the fact that several very prominent fanciers who saw it at Cleveland have told us that they consider it the most beautiful variety of gladiolus that they have ever seen. Good commercial whites have always been a rather scarce article, and on account of its fine performance Solveig gives great promise of being due for a big future as a commercial flower as well as an exhibition variety.

Among the smaller whites, we admire Marie Kunderd for its artistic ruffing. A final perky twist at the tip of each petal confers a charming touch of frivolity to the personality of this flower. We like Snow clory for its unique pencilling of iris blue. Mary o'Mine is a rather large sort with long fingerlike petals. IIrs. F. C. Hornherger can show a beautiful frilling and a most refined type of beauty, but wants plenty of moisture to give its best. Vaughan's White, Carmen Sylva, Helen Wills, and Albania are good standard commercial sorts, but rather too plain to be very thrilling to the fanciel. Giant learl resembles Pfitzer's whites. Mrs. K. I'restgard is a temperamental sort, but when it opens up eight pelfectly placed, waxy, ruffled florets at one time, as it did for us the past summer, it can be among the best.

Coronado- We have had this with four or five splendid florets open at once, but reports agree that this glad is very variable in performance. The large, lacy, purple blotch may be very fine or quite ordinary. Earl Benbow-a refined beauty with a small soft round blur of lavender leep in the throat. Recurved like a white rose. White Knight - a smaller Coromulo that aplears to be a much better performer.

Of the blotehed sorts with searlet throats, Hemy C. Goehl. Madam Georoc Boulall, Ime. MounetSully, Odulisque and Mibloom are very similar. The first two are faintly blushed pink. Mme. Sully and Odalisque are our favorites, both having fine substance and many waxy florets open at one time. Odalisque has the larger blotches. Mibloom has a pink reflection on the upper petals, and is also said to be fragrant, tho I have never checked on this point. It should be an interesting sort to try.

The remaining glads in this blotched section differ from the preceding in three particulars: they are ruffled. are late bloomers, and have much smaller blotches. Hollyhock is distinguished by its wellrounded florets. Snow Boy is a typical Kunderd ruffled variety with a small red plume. S. A. Kurtz can show a perfect frilling. Its rich snowy throat is wonderfully lit up by just a spark of softest vermilion fire. . . Do not hesitate to try some of these glads that we are noting as being variable. Under the good culture that all glads deserve, they will probably give you their best.

Of the Primulinus Grandiflorus, Maid of Orlealls is the largest, tho White Orchid is not small. The former is a strong growing, wille-open, creamythroated sort that should be fine for cutting. IThit, Orchid has unusually heavy midlibs, making it quite unique in form. Its throat is flusherl with both cream and lavender. Tiffany is a delicate ruffled variety that is fine for table decrrations.

\section{Description of Pure-Pinks}

Among glads, Giant Nymph has become our criterion for reliability, and tho this glad lacks the luscious beauty of some other pinks, even the connoisseur appreciates having in his garden a few varieties that can always be counted on to produce perfect spikes for cutting. We get tired of glads like Phipps and Vorton which produce only 20 r'r representative bloom. Spikes coming short in dry weather has been our other chicf cause of grief during the past two seasons. Of both these faults Giant $N y m p h$ is entirely free.

Prestgarl's Charles Lindluergh has the fine precision of form that marks the true aristocrat. Richest pure pink to a sharply defined throat of palest naphthalene yellow. An extra tine glacl. Jessie is similar to Pearl of California, but is of a slightly deeper pink and has a white throat distinct enough to be called blotched. This glad is one of Mair's best.
Decoration might be described as an improved Longfellow, tho the two rlarls are probably not related. Decoration is slightly lightr. in colol and twice as vigorous and tall. The clear scarlet flecking at the edge is very crisp and clean cut-not at all like the cloudy flecking that is considered a fault in a rlad. This variety is an excellent commercial. Stock is small, but it is a fine propagator.

Sophie Fisher has the same small red throat mark with white spearhead that (fo. J. Jorg (S.I') displays. Both these glads have an arlmirable cleancut style. Elizabeth Swartley is another of the worth-while mutations now in commerce-il warmer pink sport of 1910 Rose. Franz schubert is a deeper pink Rita Becli. F. J. McCoy is a fine stalwart glad, but looks like a Phipps seedling, and the progeny of this variety generally seem to lack personality. A very sprightly flower is Wings of the Iorning. (Continued on page 31.) 


\section{CLASS 9-SALMON-PINKS}

SUPER GLADS $\begin{gathered}\text { (Heary } \\ \text { Capitals) }\end{gathered}$ GROUP A GLADS ${ }_{\text {Capitals) }}^{\text {(Light }}$ GROUP B GLADS $\underset{\text { Type) }}{\text { (Regular }}$

\begin{tabular}{|c|c|c|c|c|c|}
\hline $\begin{array}{l}\text { Originator } \\
\text { Alliemade }\end{array}$ & Year: & $\begin{array}{l}\text { Size } \\
\text { EF }\end{array}$ & Substance & Variety $\quad$ Unit & Price \\
\hline $\begin{array}{l}\text { Alliemade } \\
\text { Alkemade }\end{array}$ & 1927 & $\begin{array}{l}\text { EE } \\
\text { EE }\end{array}$ & B & BAR. VAN WYNBERGEN $\$$ & 2.50 \\
\hline Mair ......... & .1927 & $\mathrm{EE}$ & $\mathrm{C}$ & BETTY & $\begin{array}{l}1.00 \\
1.00\end{array}$ \\
\hline Mair & .1929 & $\mathrm{EE}$ & $\mathrm{C}$ & CALEDONIA & 4.00 \\
\hline Velthuys & .1928 & $\mathrm{EE}$ & $\mathrm{B}$ & CAROLUS CLUSIUS** & .07 \\
\hline Coleman & .1919 & $\mathrm{EE}$ & B & CATHERINE COLEMAN" & .10 \\
\hline Goodrich & 1925 & $\mathrm{EE}$ & $\mathrm{B}$ & DR. A. C. HANSON & .15 \\
\hline Velthuys & 1916 & EEE & $\mathrm{B}$ & Early Sunrise & .20 \\
\hline Vaughan & 1929 & $\mathrm{E}$ & $\mathrm{B}$ & Edith Mason* & .25 \\
\hline Errey ....... & 1928 & $\mathrm{EE}$ & $B$ & ESME DESAILLY ** & .75 \\
\hline Austin & .1916 & $\mathrm{E}$ & B & Evelyn Kirtland*** & .05 \\
\hline Funderd. & .1921 & $\mathrm{E}$ & $\mathrm{B}$ & Favorite ${ }^{*}$ & .10 \\
\hline Williams & .1925 & EE & $\mathrm{B}$ & Fay Lanphier & .05 \\
\hline Salbach & 1928 & $\mathrm{EE}$ & $\mathrm{C}$ & Frank M. Schick" & .20 \\
\hline Joerg . & 1924 & $\mathrm{EE}$ & $\mathrm{B}$ & GEORGE J. JOERG * & .12 \\
\hline Phipps & 1926 & EEE & $\mathrm{C}$ & Helen Phipps & .20 \\
\hline Palmer. & 1930 & $\mathrm{EE}$ & A & INSPIRATION & 5.00 \\
\hline Mair & 1929 & $\mathrm{EE}$ & $\mathrm{B}$ & JOHN RAMSAY & 5.00 \\
\hline Ellis & 1926 & $\mathrm{E}$ & $\mathrm{B}$ & Lady Lorene & 1.00 \\
\hline Ogrodnichek & .1932 & $\mathrm{EE}$ & $\mathrm{B}$ & MARGARET FULTON***. & .50 \\
\hline Kunderd & 1918 & $\mathrm{E}$ & $\mathrm{B}$ & Marshall Foch* & .05 \\
\hline Ellis .. & 1926 & $\mathrm{E}$ & $\mathrm{A}$ & Monarch of the Glen**. & 1.00 \\
\hline Diener & 1920 & EEE & $\mathrm{C}$ & MRS. LEON DOUGLAS. & .05 \\
\hline Stevens, F. H. & 1930 & $\mathrm{EE}$ & $\mathrm{B}$ & NETHERLAND PRINCE*... & 2.00 \\
\hline Ellis & .1928 & $\mathrm{EE}$ & $\mathrm{C}$ & Point Twain & .40 \\
\hline Diener & .1917 & $\mathrm{EE}$ & $\mathrm{C}$ & RICHARD DIENER & .05 \\
\hline Phillips & .1930 & $\mathrm{EE}$ & $\mathrm{B}$ & RITA PHILLIPS* & 6.00 \\
\hline Salbach & 1929 & $\mathrm{EE}$ & $\mathrm{B}$ & SALBACH'S PINK* & .50 \\
\hline Mair .... & 1929 & $\mathrm{EE}$ & $\mathrm{B}$ & SENATOR* & 5.00 \\
\hline Symons & 1928 & $\mathrm{EE}$ & $\mathrm{C}$ & Silversheen & 8.00 \\
\hline Kunderd & 1928 & $\mathrm{E}$ & B & T. A. Weston*** & .25 \\
\hline Eriey & 1928 & EE & I; & Tinamba** & 1.00 \\
\hline Diener & 1921 & EEE & C & W. H. PHIPPS (MR.) & .05 \\
\hline
\end{tabular}

SALIMON PINKS WITH YELLOW THROATS

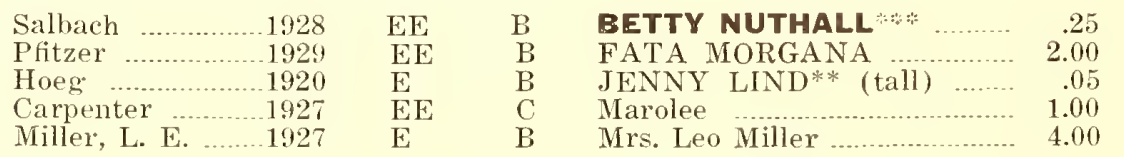

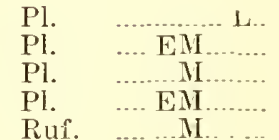

\begin{tabular}{|c|c|}
\hline $\begin{array}{l}\text { Season } \\
\text { EM. }\end{array}$ & Deficiencies \\
\hline$M$ & \\
\hline M. .... & \\
\hline .M. $\ldots \ldots$ & \\
\hline EM. & \\
\hline ML .... & $3,23,27$ \\
\hline EM........ & \\
\hline iI $\ldots$ & $2,24 \ldots$ \\
\hline ML .... & \\
\hline M............ & \\
\hline M $\ldots \ldots$ & \\
\hline . HI....... & 7. \\
\hline$M$ & . \\
\hline MI...... & \\
\hline ML .... & 29. \\
\hline .I $\ldots \ldots$ & $19 \ldots \ldots$ \\
\hline VI & \\
\hline EM ........ & . \\
\hline . $I \ldots \ldots$ & . \\
\hline M & ............. \\
\hline ML .... & \\
\hline ML .... & $6,17 \ldots$ \\
\hline$M$ & \\
\hline EMI & \\
\hline ML .... & $10,21 \ldots$ \\
\hline HI.............. & ?............ \\
\hline ML .... & \\
\hline ML .... & . \\
\hline MI......... & 3 \\
\hline EM ............ & ................ \\
\hline L. & 20,2 \\
\hline
\end{tabular}

SALMION PINKS WITH PRONOUNCED THEOAT BIOTCEIS

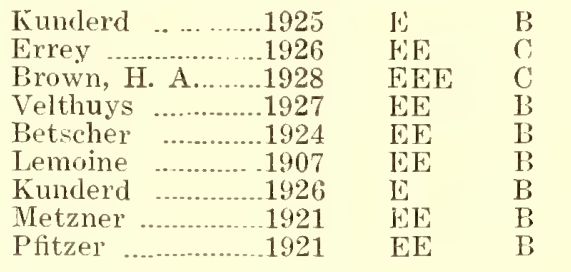

A. E. Kunderd

.08 EDITH ROBSON

Emma

Iwa** .05

Jean du Taillis ….................... .10

J. OGDEN ARMOUR …........ .10

Marietta**

Type

Pl.

Pl.

$\mathrm{Pl}$.

Pl.

Pl.

$\mathrm{Pl}$.

Pl.

Pl.

$\mathrm{Pl}$.

Ruf.

$\mathrm{Pl}$.

$\mathrm{Pl}$.

$\mathrm{Pl}$.

Ruf.

$\mathrm{Pl}$.

Pl.

Pl.

Ruf.

Ruf.

$\mathrm{Pl}$.

Pl.

Ruf.

$\mathrm{Pl}$.

Pl.

$\mathrm{Pl}$.

$\mathrm{Pl}$.

Ruf.

$\mathrm{Pl}$.

Pl.

TRUDEL GROTZ …............ 10 Pl

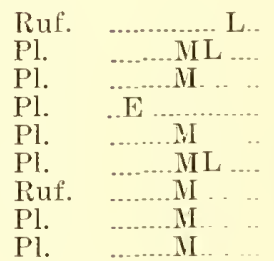

19

$7,12 \ldots$

\section{PRIMULINUS GRANDIFLORUS}

\begin{tabular}{|c|c|c|}
\hline Ellis & .1926 & $\mathrm{E}$ \\
\hline Palmer & 1928 & $\mathrm{EE}$ \\
\hline Bales. & 1930 & EE \\
\hline Purple & 1928 & $\mathrm{EE}$ \\
\hline Purple & 1926 & $\mathrm{EE}$ \\
\hline Betscher & 1922 & $\mathrm{EE}$ \\
\hline Wentworth & .1932 & $\mathrm{EE}$ \\
\hline Palmer & 1931 & EEE \\
\hline Stevens, F. & 1929 & $\mathrm{EE}$ \\
\hline Purple & .1926 & $\mathrm{E}$ \\
\hline Palmer & .1932 & $\mathrm{E}$ \\
\hline
\end{tabular}

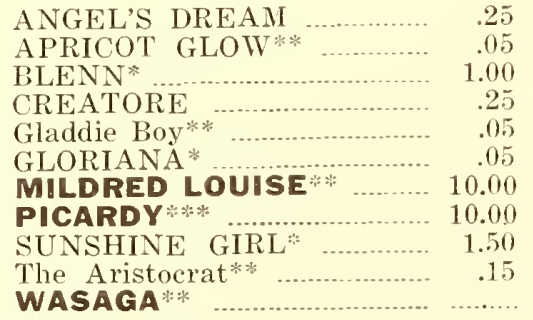

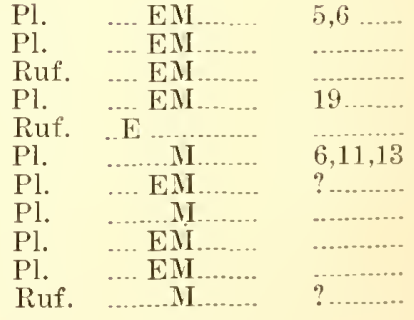




\section{Description of Salmon-Pinks}

A very numerous tribe, but, except for several newcomers, one which has contained few real Super Glads, is the Salmon-Pink class. Salmon seems to be sort of a "natural" color for glads, and tho we list 58 varieties in this color class, if you find any old favorites missing from our list of 500 , there is more than half a chance that they will be salmonpinks. We couldn't list them all.

Everyone knows and loves W. H. Phipps and has probably wished that it produced with greater frecuency its magnificent spikes of warm salmonpink. Now that it is way down in price, everyone can grow it in quantity and get all the fine spikes of it that he may want. Plipuss will commonly open over fifteen florets at one time. . . Mrs. Leon Doug. las, another sensational giant of the past decade, has probably passed the zenith of its popularity, now that size has been bred into giads of finer color.

IIargaret Fulton is a newcomer into the rank of famous glads. We were so favorably impressed by this valiety at the Cleveland show, that we accomyanied the originator to his home in Pennsylvania to view his planting of it. Mr. Ogrodnichek had a sizable stock, and tho it had been g.rown on good coil in an area which harl had sufficient rainfall, we were struck by the remarkable uniformity of pelformance which this variety displayed. It equalled Givnt N"/mpll in this respect, and it is certainly a much more beautiful glad, tho somewhat smaller. We did not notice a single crooked spike and every flower head had five unwilted blooms open at noon of a moderately hot day. Spikes averaged 18 florets and buts, but we cannot, of course, say what the length of spike would be in a dry seasoil. . . In color Moryunt Fulton is a very rich, deep salmon pink, of an unusually solid color-the same shade in the throat as at the tijs of the petals. There is a faint suggestion of apricot in the throat on (one petal, but no lines or markings of any kind. Substance is very good and rather velvety. Thr florets are the roundest we ever saw in a glad, being so because many of the petals are themselves as round as a dollar. These round, unrecurved florets are closely set in a double row, but are not crowded. Florets are foul inches across and up to ten may be harl open at once in cloudy weather, or by blooming indoors. We took a few spikes with us when we left Venango and found that they bloomed sut perfoctly in water. Morruret Fulton looks like the best commercial in its color that we have ever seen. It is a very rapid propagator. While we wouldn't want anyone to invest heavily in a glad we have not grown and tested ourselves, we do recommend Maryoret Fullow for trial. The originator is selline this rariety for the same price as we are and positively refuses to part with anything except $\mathbb{N} 0.1$ bulbs, We are not boosting this glad because of any great profit we expect to get out of it, as wo are allowed only the customary $30^{\prime}$ c commission, but because the Colonial Crardens wants the privilege of recommending to the fans new things that seem to be meritorious.

Baron lan Wynbergen has the small purple throat marking of catherine coleman. Iieat llt has a small red and white marking. Betty is true salm. on color rather than salmon-pink. A distinct and beautiful variety with a white throat. Caledonia is not quite so distinct, but builds a fine spike; a light salmon pink. Carolus ('lusius has a very lovely deey salmon-vink color-very much the same as Wuryart Fultom. It is a little deever than the color of Hulle!l and almost a pure self. Floret. favor the
" $B$ " form, i. e. have one throat petal, and are much larger than was the case with Halley. There are also more open. A very beautiful glad.

Dr. A. C. Hanson is a fine performer with throat markings like Vinuct. Early Sunrise-red salmon. Edith Mason might almost go into either the PurePink or Light Pink class. Esme Desailly has a slight pencilling in the throat, well rounded flowers, a tall spike. Favorite sometimes approaches orange, making a very rich color. Fay Lanphier is a very beautiful, frosted pink. Frank M. Schick has many very silky, recurverl florets open at one time. IIany of these varieties listed in small type are real beauties. There are so many good glads in commerce today that a list of neither one hundred nor three hundred suffices to take care of all the really good ones.

Inspiration is a heavy-petaled, laciniated seedling of Cloriuna $x$ bennett. Color is much like Glorirum, but Inspiration is well opened. John Ramsay is a medium salmon-pink that makes a long spike with many open. Latly Lorene and l'oint Twain approach Mis. Sisson (L.P.) in color. The latter has a charming rufting. Ilonarch of the Glen has a much warmer tone.

Netherland Prince is a rich apricot pink, not quite so warm a colol as Pir(u)dl. Spike is very substantial and placement good. We recommend this for trial. . . Richard Diener is a smaller, warmer II. H. Phipms. R:ta l'hillips resembles Picardy, but has an even warmer apricot tone; the throat displays a soft scarlet feather. This looks very promising and like all the new things, is given only a tentative rating. Salbach's I'ink is a fine deep pink and a good performer, but seems to lack distinction. Senator makes a heavy spike of deep salmon, flecked with scarlet. Silversheen did not impress us: the large spike hardly compensated for the narrow petals and mediocre throat. T. A. Weston is a smaller glad of great beauty: a pure salmon pink very finely frilled. 'Tinamba is a vigorous light sort with considerable flecking which you may or may not like.

While a bouquet of Betty Nuthall has a glowing effect faintly suggestive of orange, scrutiny of a single spike shows it to be a warm salmon-pink with a yellow throat. This splendid glad is a stalwart grower and consistent performer.... Fata Moryana is not the performer that Betly is but the throat profits by the absence of the slight pencilling of red that the latter displays. . . Jenny lind (tall strain) is still one of our loveliest glads. Marolee is a vary large reddish salmon with a pronounced yellow throat. Mrs. Leo Miller is a small, nicely ruffled glad of a light salmon color with a creamy throat.

Among the blotched sort: Edith Rohson is perhaps our favorite. Substance is only fair, but it builds a great spike. The blotch is lather small. Trudel (irot\% one of the parents of P'fitzer"s Triumph, can be very fine whon well grown. . . We like the crisp ruffing and sharp, round bloteh of $J$ Ogden Irmour. .. . Emma and Jean I)u Taillis have a blurry sort of bloteh that in the latter particularly produces a flushed or foverish appearance. I wa is a fine, elean-rut sort that has done well for us. Alpheu is a lighter Edith Robson of trimmer form. The individual florets of A. E. Kunderd are very rich and distinctive.

In Picardy we have the only thing in sight which is likely to supplant II, H. Phipps as oul most popular pink glad. Picordl" is truly a ravishing beauty. In form it has inherited $75{ }^{\circ}$ of the charac(Continued on page 31.$)$ 


\title{
CLASS 10-LIGHT-PINKS
}

\author{
SUPER GLADS $\begin{gathered}\text { (Heavy } \\ \text { Capitals }\end{gathered}$ \\ GROUP A GLADS (Light \\ GROUP B GLADS $\underset{\text { Type) }}{\text { (Regular }}$
}

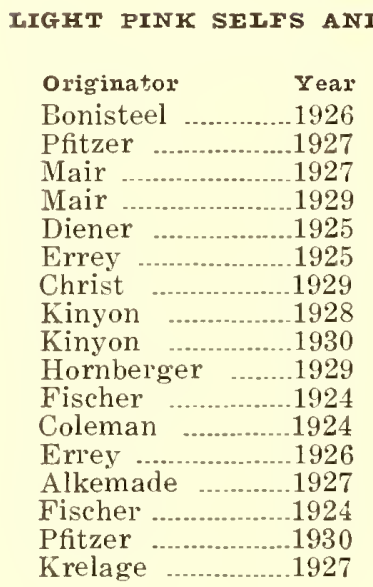

$\begin{array}{ll}\text { Size } & \text { subst } \\ \text { EE } & \\ \text { EE } & \text { B } \\ \text { EE } & \text { C } \\ \text { EEE } & \text { C } \\ \text { EE } & \text { BE } \\ \text { E } & \text { EE } \\ \text { EE } & \text { B } \\ \text { EE } & \text { B } \\ \text { EE } & \text { C } \\ \text { EE } & \text { B } \\ \text { EE } & \text { B } \\ \text { EE } & \text { B }\end{array}$

\begin{tabular}{lr}
\multicolumn{1}{c}{ Variety } & Unit \\
Brice \\
Con Echo*
\end{tabular}

Type

$\mathrm{Pl}$.

Pl.

Pl.

Pl.

$\mathrm{Pl}$.

Pl.

Pl.

Pl.

Pl.

Ruf

Pl.

$\mathrm{Pl}$.

$\mathrm{Pl}$.

$\mathrm{Pl}$.

Pl.

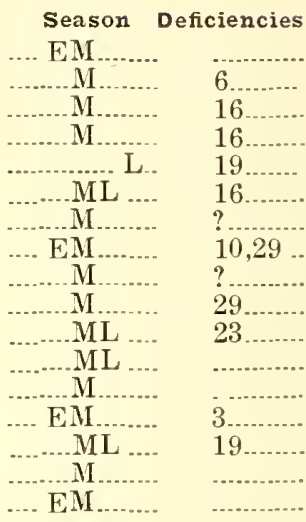

LIGHT PINKS WITH LARGE CREAM OR WHITE THROATS

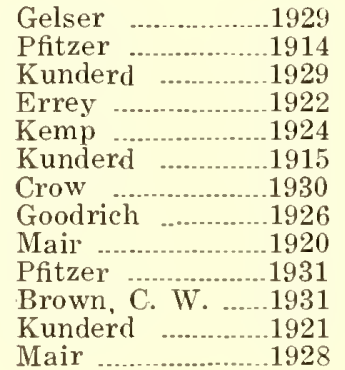

$\begin{array}{ll}\text { E } & C \\ \text { EE } & \text { C } \\ \text { E } & \text { C } \\ \text { EE } & \text { C } \\ \text { EE } & \text { B } \\ \text { EE } & \text { B } \\ \text { EE } & \text { B } \\ \text { E } & \text { B } \\ \text { EE } & \text { B } \\ \text { EEE } & \text { C } \\ \text { E } & \text { B } \\ \text { E } & \text { B } \\ \text { EE } & \text { B }\end{array}$

Alice Reid

Appleblossom (P)

BLUSHES OF CR

Gertrude Errey

JUNIATA

MRS. T. E. LANGFORD $* 3.00$

OLIVE GOODRICH**

Princess Mary ..................... .50

ROSEMARIE PFITZER .... ........

$\begin{array}{ll}\text { Sunny Jim } & \\ \text { VIRGINIA HALE**..........- } & .50 \\ \text {. } & .10\end{array}$

WM.CUTHBERTSON(MR.) 1.50
Ruf.

$\mathrm{Pl}$.

$\mathrm{Pl}$.

$\mathrm{Pl}$.

Ruf.

Pl.

Ruf.

$\mathrm{Pl}$.

Ruf.

Ruf.

Ruf.

Pl.

Ruf.
.... EM

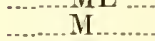

M....................

… EM

.... EM

ML

M

E

$\mathrm{E}$ M

M

$7,29 \ldots$

6,23 .

?...........

19

IIGHT PINKS WITH PRONOUNCED THROAT BLOTCHES

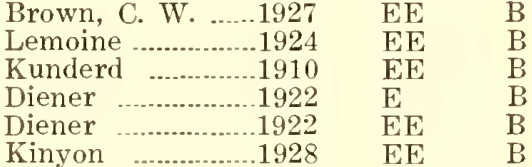

PRIMULINUS GRANDIFIORUS
Kingsley _.............1930

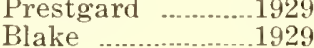

$\begin{array}{ll}\text { EE } & \text { C } \\ \text { E } & \text { B } \\ \text { E } & \text { B }\end{array}$

ADELPHA *

LOTUS*

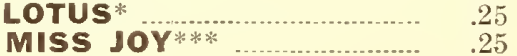

BLEEDING HEART $* * \cdots$

ELEONORA DUSE …........ 1.00

Mrs. Frank Pendleton* ........ .05

MRS. H. E. BOTHIN ${ }^{*} \ldots \ldots \ldots . . .05$

MRS. JOHN R. WALSH*... . .07

RESPLENDENT*
Pl.

Pl. … EMI.....

Pl. … EM EM.....

Ruf. .................

Ruf. ........ML ...

29

$23 \ldots . . .$.

Ruf.

M......

Ruf.
Pl.
Pl. .... EM 


\section{Description of Light-Pinks}

The Light Pink class brings us to the very heart of gladiolusdom. What a roster of exquisite beauties this color section calls to mind!

We don't ordinarily expect outstanding richness and delicacy in the same glad. But Nature was lavish when she produced lush, full-petaled Coryphee. With its snowy throat and ravishing tint of pink, it is unsurpassed in exquisiteness; yet its full round florets have the rich melting texture of Pfitzer's Triumph. Such perfection makes us charitable of its one fault, in a way that we could not be, perhaps, with any other glad.

Mair's Dignity is a very pale, cool pink of a delicate translucency. Lovely, but will not stand rough weather. Elizabeth is of a warmer color and more opaque substance. Both these glads may be glown to almost triple "F" size. . . Frederick Christ can he very fine, but too often chooses not to be. Of the family of IF. H. Phipps, but less robust. Lacks the purity of color of Coryphee.

Like Dignity, Ivernia is lighter than the average run of glads in this group. . . We like Mary Marie for its uniqueness. Its very pale pink is heavily and cleanly striped deep rose, producing the nearest approach to a striped glad that we know (except Othello [B] ). A good novelty that we recommend. Prof. Van Slegteren is a paler Catherine Coleman.

Mrs. P. W. Sisson is a melting shade of warm light pink, moderately ruffled and nearly a self. Well grown, this is one of the most beautiful glads in existence. . When it comes right, Rita Beck can be a breath-taking beauty. To the lovely purity of its soft round florets is added a placement immaculately neat. There is a serene, chaste spirit about this flower. Five to seven tiny red lines deep in the throat add a touch of character and individuality. . . Schwaben Girl resembles Mrs. Sisson, but has rounder, unruffled florets and is even more of a self. A real beauty that opens plenty of florets at one time... Yvonne might be called the improved Le Marechal Foch. It has a much longer spike but the same fleshy texture. Blush-white with a small round blur of rose deep in the throat. Can be grown to "EEE" size.

Leviathan is quite similar to Schuaben Givl, Mary Lockwood to Rita Beck. Bon Echo and Miss New York are fine clear light pinks. Mrs. Harriet M. Whitcomb has fine round florets. In color it is composed of two similar shades sharply and cleanly interflecked. Panope has a warm cream throat.

Alice Reid-a glad with the girlish charm of Annie Laurie. Edges of petals very attractively waved. Appleblossom - true appleblossom coloring: white splashed pale pink. Seems as if this glad ought to be fragrant. Blushes of Cream-a silky, creamy pink, like Paramount. Gertrude Errey-a touch of red deep in the throat lends distinction to this dainty, white-throated flower. Juniata-another blithe spirit in the world of glads. A soft pink with creamy throat, possessing fair size and sprightly form.

In New England and Canada, where it does better than in the Middle West, Mrs. Mr. Norton would probably still be rated a super-glad. Virginia Hale is a similar, slightly smaller pink with large creamywhite throat, that is a much better performer. Sunny Jim is a golden-throated seedling of Prince of Wales.
Mrs. T. E. Langford is a seedling of Mrs. Norton and in oul estimation an even more beautiful flower, tho it may not prove so popular with florists on account of not having as much pink in its makeup. It has a glorious rich cream throat, minus the faint sanding seen in Norton. Edges of petals are very delicately waved. This glad seems to be a better performer than Mrs. Norton, and we believe that it will be very widely grown. . . Olive Goodrich is almost a picotee: white with a pink edge. This glad has fine form and substance beautifully waxy, like a lily. ... Rosemarie P'fitzer-this great beauty was pictured in the Gladiolus Revicw for December (1931).... Wm. Cuthbertson-a highly temperamental solt that can be very thrilling. Very heavily crimped cup-like florets of light rose-pink, blending to a very large white throat. . . . I'rincess Mary-a slightly pinker version of Queen Mary. Throat a bit less perfect.

IBleeding Heart-the improved Mrs. Pendleton; smaller florets but many more open. Eleonora Duse -another good blotched one by Lemoine. Flat blooms; almost white. Mrs. H. E. Bothin-a starryeyed beauty. A sister glad to Mrs. Walsh; more dainty and less voluptuous than the latter.

Mrs. John R. Walsh-Your enthusiasm for this glad will depend on the extent of your liking for blotched varieties. If you aren't strong for them, you probably won't like it; if you are, you will certairly swear by Walsh. Probably the most striking of all blotched glads. The lavish blotches of richest velvety crimson almost cover the whole of the lower petals-as if there had been a tiny explosion at the heart of each flower. Florets are well ruffled. This glad is the exact counterpart of Bennett in performance, having thrown regularly during the past season spikes of $18-20$ buds with six large florets open at one time.

Resplendent-so light as to be almost in the cream class. Fine waxy substance; small distinctive blotch. Very good.

Adelpha has a fine cream throat and is nicely ruffled. A glad of real charm.

Lotus-the one glad for which we reserve the adjective ethereal. Resembling Mrs. Langford more closely perhaps than any other glad, it displays an even more exquisite blend of pink and white and cream. Lotus probably possesses the daintiest coloring of any glad in existence. As one flower lover. remarked, "It looks as if it would evaporate." Substance is very bland and waxy. J)r. James B. Maple, President of the Indiana Gladiolus Society, who grew 1200 varieties in 1930 pronounced this one of the twelve finest glads he had seen that season. Lotus has been mentioned twice in the Review by Prof. Pridham for its wonderful sheen. An ideal cut flower for local use, but not a shipper.

Iiss Joy-another splendid Primulinus Grandiflorus. About the color of $M r s$. Sisson but with a pure cream throat. Entirely without markings. Three or four large florets open at a time. A tall grower that stands perfectly in the field and did not throw one crooked spike for us despite the extreme heat of the past season. Strongly recommended. 


\section{CLASS 11-ROSE-PINKS}

SUPER GLADS $\begin{aligned} & \text { (Heavy } \\ & \text { Capitals) }\end{aligned}$

GROUP A GLADS ( $\begin{gathered}\text { (Light } \\ \text { Capitals) }\end{gathered}$

GROUP B GLADS $\underset{\text { Type) }}{\text { (Regular }}$

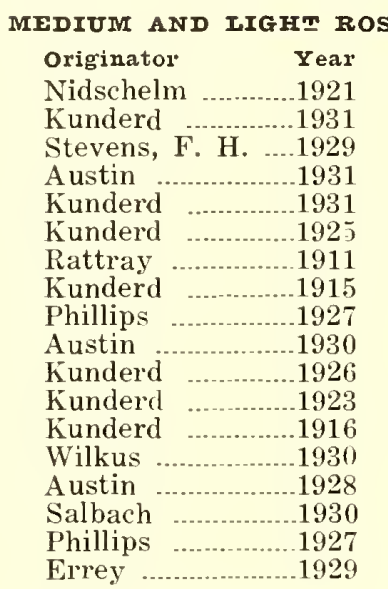

\begin{tabular}{lc}
\multicolumn{2}{l}{ PIN K } \\
Size & substance \\
EE & B \\
EE & B \\
EE & B \\
EEE & C \\
E & B \\
E & B \\
EEE & C \\
E & C \\
EEE & C \\
EE & C \\
E & B \\
EE & A \\
E & B \\
EE & B \\
EEE & C \\
EEE & B \\
EEE & C \\
EE & C
\end{tabular}

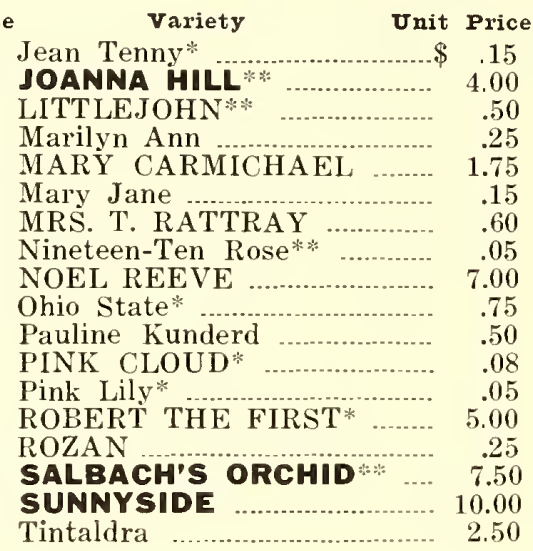

Type
Pl.
Pl.
Ruf.
Pl.
Pl.
Pl.
Pl.
Pl.
Pl.
Pl.
Pl.
Ruf.
Pl.
Ruf.
Pl.
Pl.
Pl.
Pl.

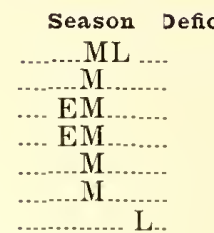

\section{ciencies} 11 .......

(1)...... $2,13 \ldots$ $2,13 \ldots$ 1,19 E ......ML .... $19 \ldots$

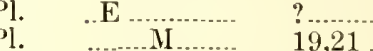

Ruf. …............ 7

Pl. … EM ....... 29

Ruf. …........ ... 29 .... EM

$1,17,21$

Pl.

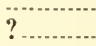

\section{DEEP ROSE PINKS}

Symons …...........1927

Kunderd .............1928

Arenius ...............1931

Kunderd ..................1916

Lemoine ................1909

Kunderd .................1929

Le Clerc $\quad 1908$

Lemoine .................1922

Chriswell _.................1924

Mair 1930

EE

EEE

AMETHYST**

EE

E

COL. CHAS. LINDBERGH

CONSTANCY

CRINKLES*

EE

E

CUFE IEFE

Gorgeous

HERNANI

Paul Deschanel

PRIDE OF WANAKAH ${ }^{*}$ *

ST. NICHOLAS* $\quad 5.00$

EE

EE

Kunderd

1923

$\mathrm{EE}$

Sweet Rose**

WONDERFUL*

.75
.50
5.00
.05
.08
.60
.50
.50
.05
5.00
.07
.00

Ruf.

Pl.

Pl.

$\mathrm{Pl}$.

$\mathrm{Pl}$.

$\mathrm{Pl}$.

Pl.

Pl.

Pl.

Pl.

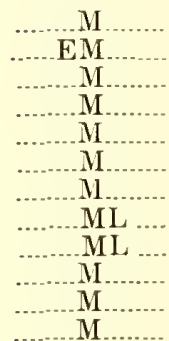

$?$

….............

$(-\cdots+\cdots$

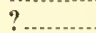

7,29

PRIMUIINUS GRANDIFLORUS

Fischer

1923

$\mathrm{E}$

ROSE MIST*

.07

Pl.

EM

\section{CLASS 12-ROSE-REDS}

MEDIUM AND IIGHT ROSE REDS

\begin{tabular}{|c|c|c|}
\hline Kunderd & ........1930 & $\mathrm{E}$ \\
\hline Kunderd & 1927 & EE \\
\hline Kunderd & .1925 & $\mathrm{EE}$ \\
\hline Kunderd & 1930 & EE \\
\hline Kunderd & 1926 & $\mathrm{E}$ \\
\hline Lemoine & .1922 & EE \\
\hline Kunderd & $\ldots . . . . .1927$ & EE \\
\hline Palmer ... & ....... 1931 & EE \\
\hline Gilrey .... & 1927 & $\mathrm{EE}$ \\
\hline Stevens, I & F. H. 1928 & EEE \\
\hline Errey ...... & 1928 & EEE \\
\hline Crow & .1929 & EE \\
\hline Kunderd & .1921 & $\mathrm{E}$ \\
\hline McKibben & 1930 & $\mathrm{EE}$ \\
\hline Kunderd & $\ldots 1927$ & $\mathrm{EE}$ \\
\hline
\end{tabular}

Kunderd $\quad 1927$

DARK ROSE RED

Kunderd

1916

EE

A

CLAUDE BOWERS*

DR. L. H. BAILEY*

$\$ \quad .60$

DR. NELSON SHOOK *.......

Georgia*:

MARECHAL FAYOLLE ..... $\quad 4.00$

Philatelia

PIRATE*

PURPLE VICTORY* ${ }^{*} \ldots . . . . . .6$

RAMFSSES $\quad 6.00$

RED LORY ........................ 1.00

SULTAN (C)

Taro* 05

W. G. HATFIELD** ... 4.00

Wm. Booth

.20

ROSE RED WITH WHITE THROAT

Kunderd

.1923

$\mathrm{EE}$

B

SHOW FLOWER

Pl.

Ruf.

Ruf. …..............

Ruf. ….... EU

Pl. EM

Pl. $\quad$.........ML

Pl.

Pl.

Ruf.

Ruf.

$\mathrm{Pl}$.

Ruf.

................

........M

M

Pl.

Ruf.

.......

EM.

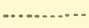

$?$

27.

$5 \ldots \ldots . .$.

19,29 .

?........... 


\section{Description of Rose-Pinks}

An unusual situation prevails in the rose-pink class: while we have plenty of fine rlads in this section, scarcely any of them (except Salbach's Orchiel and Sumnisside) can be said to stand out as being definitely superior to many of the others. Instead of Ioarina Hill and Col. Charles Lindbergh, almost any other two varieties in light capitals might have been chosen equally well.

Joanna Ilill is a solid, medium rose-pink, of about the shade of Pirli Lily. Substance is unusually opaque and velvety for a glad in this color class. The creamy-white pencil on the lower petals is so pronounced as to appear almost raised or embroidered. Salbach's Orchid seems to stand between Minuet and Mrs. Sissom in appearance, being somewhat closel to the latter. It will open more florets, however than either Himuct or Mrs. Sisson. A really beautifully glad that looks quite promising.

Surmuside is the only glad of the 500 in our list with which 1 am not personally familiar, our stock of this variety having been too small to bloom. However, I secured the necessary information about this variety from other sources, in which I have complete confidence, and it comes so highly recommended both in America and abroad that I felt that there could be no question about it. deserving to rank in the First Hundred. Hence the single departure from our rule to list in the "best 500 " only glarls with which we are personally acquainted. ... Sunnyside is deseribed as being a delicate rose-pink, shading to deeper at the tips. It has very large, round florets, with just a touch of recurvature, reminiscent of Rosemarie Pfitze'r. Performance is described as highly regular. A glad to look forward to.

Noel Recve may deserve a higher rating upon further testing. It is saicl to be variable and probably we have not grown it to its best or even acclimatized it yet. A medium-light rose-pink of translucent substance. Florets well rounded and many open.

Mrs. T. Rattray would probably have become more popular in America, had we not had our own W. $H$. Phipps, which has both a warmer and purer color.

Mary Carmichael-an improved Paramount with an exquisite lavender sheen. Littlejohn has better color and a longer spike than $E$. J. Shaylor, which it may supplant. Robert the First builds a tall spike of palest rose cleanly flecked with a slightly deeper shade. A distinctive flower. Rozan-a giant spike of a wonderfully clear pink, just cool enough to put into this class. Pink Cloud-a massive sort in pale rose-pink verging on lavender. The small salmon blotches look a bit incongruous.

I'auline Kunderd is a rich rose-pink with a distinct yellow throat. Mary Jane-a smaller, pinker Minuet. Ohio State and Iiarilyn Ann are very large sorts with lighter throats and more or less suggestion of veining on the reverse of the petals. Jean Tenny - large silvery rose-pink. Tintaldra shows the characteristic Mrs. Rattru!f throat marking of red on white.

Among the deep rose-pinks, it is even harder to pick out anything outstanding than in the preceding section. As I have seen it grown, Pride of Wanakah (deep rose with a darker throat) has produced the finest spikes of anything in this color group. It has not been quite that outstanding with us, tho very good. My own favorite would probably have been the smallest of the lot-Crinkles, but I lacked the nerve to call it a super-glad, tho I believe this valiety is staging a comeback in popularity. Crinkles has always been a great favorite with garden visitors. For those who have not seen this glad, it might be described as a deep rose color (deeper than rosepink) with small round florets which are very heavily ruffled or crimped. The whole effect is very precise and rich.

Our final choice for the First Hundred proved to be Col. Charles Lindbergh. This glad, like Amethyst and St. Nicholas is unique in color and hard to place. It could be called almost equally well rosepink. rose-red, or lavender.

Eugene Le Febvre is of the family of Rouget $D$. Lisle, with a large throat bloteh rimmed with white. Very distinctive. Georgeous has a throat almost black. Hernani resembles Amethyst, but has considerable yellow in the throat. Constancy, Sweet Rose, and Wonderful remind one of Pride of Wamakah. All are fine glads. I'aul Deschanel-a rather mottled sort; cerise blotch.

Rose Mist-crushed strawberry with a buff edge. Very artistic in a rather nonchalant way.

\section{Description of Rose-Reds}

We have masle our only radical departure from conventional color classification in the case of Purple Glory. There has always been an argument as to whether this glad belonged to the Purple section or to the Dark Red, but after several times checking it by Ridgeway's, we found that there was more black in its composition than violet, and yet there was too much of the latter also to make it a true maroon. According to lidlgeway's it is a dark rose-red. 'This view is supported by the fact that most of the varieties in this color class today are seedlings of Purple Glor".

Our favorite in the Rose-Red class is Sultan, a seedling of Priple (ilmy and Ir. F. F. Bermett. sultre is very similar to Red lory in color, but has a greater purity of tone. It opens its florets more widlely than Pirple (ilor". The color of all of these rose-reds is very sinilar, and Sullan is not greatly different from Taro or IJr. Nelsom Shook, tho hap- pily it is essentially a self-color, without the darker feather of the latter two varieties.

It is hard to pick a favorite among Kunderd's seedlings of Purple Glory. Shook and Taro both seem variable in size of bloom they are willing to give. These varieties are almost identical; hence a lower rating for one of them (Taro) on the score of distinctiveness. Claude Bowers has cup-like florets of a splendid purity of tone. Even better, perhaps, is the brilliant I)r. L. H. Bailey. I'hilatelia is more subdued in tone and makes a conservative, close-set spike. Georgia has florets set well apart. Our favorite, however, is F. C. Vick. which is lighter than Sultan and the other leaders and hence aequires some additional merit for uniqueness. E. C. Vicli has wide-open florets of a very vivid, light rose-red.

Pirate may deserve a higher rating upon further trial. It has large florets with plenty of character.

(Continued on page 31.) 


\title{
CLASS 13-LAVENDERS
}

\author{
SUPER GLADS $\begin{aligned} & \text { (Heavy } \\ & \text { Capitals) }\end{aligned}$ \\ GROUP A GLADS (Iight \\ GROUP B GLADS $\underset{\text { Trpe) }}{\text { (Regalar }}$
}

LAVENDER SELFS AND NEAR-SELFS

\begin{tabular}{|c|c|c|c|c|c|}
\hline Originator & Year & Size & Substanc & Variety & t Price \\
\hline Mair & .1927 & $\mathrm{EE}$ & $\mathrm{C}$ & A. E. AMOS & 1.00 \\
\hline Mair & .1918 & $\overline{\mathrm{EE}}$ & B & BERTY SNOW* & .20 \\
\hline Hoeg & .1925 & $\mathrm{E}$ & B & BUFFALO BILL** & .10 \\
\hline Kunderd & .1917 & $\mathrm{E}$ & B & BYRON L. SMITH* & .05 \\
\hline Kinyon & 1927 & $\mathrm{EEE}$ & $\mathrm{C}$ & DR. MOODY* & .15 \\
\hline Brunelet & 1907 & $\mathrm{E}$ & B & Florence. & .10 \\
\hline Kunderd & 1927 & $\mathrm{E}$ & B & Fuld's Favorite & .20 \\
\hline Austin & 1926 & $\mathrm{E}$ & $\mathrm{C}$ & High Nye & .05 \\
\hline Austin & .1931 & $\mathrm{EEE}$ & B & IDABELLE FIRESTONE* & 1.50 \\
\hline Kunderd & .1917 & $\mathrm{EE}$ & B & Indian Summer & .05 \\
\hline Prestgard & .1926 & $\mathrm{EE}$ & B & JANE ADDAMS* & .15 \\
\hline Kemp & 1926 & $\mathrm{EEE}$ & $\mathrm{C}$ & JUBILEE & .60 \\
\hline Kunderd & 1917 & $\mathrm{E}$ & B & Kasson* & .15 \\
\hline Arenius & 1930 & $\mathrm{EE}$ & A & KANG ARTHUR & 25.00 \\
\hline Pfitzer & 1927 & $\mathrm{E}$ & B & KRIMHILDE & .15 \\
\hline Arenius & 1931 & $\mathrm{E}$ & $\mathrm{C}$ & Lavender Delight* & 5.00 \\
\hline Kunderd & 1928 & $\mathrm{E}$ & $\mathrm{C}$ & LAVENDER ROSE & 1.50 \\
\hline Diener & 1925 & $\mathrm{EE}$ & B & MME. SCHUMANN-HEINK & 2.00 \\
\hline Coleman & 1922 & $\mathrm{EE}$ & B & MINUET*** & .08 \\
\hline Prestgard & 1927 & $\mathrm{EE}$ & B & Miss Des Moines & 40 \\
\hline Kunderd & 1917 & $\mathrm{E}$ & $\mathrm{C}$ & Mona Lisa & 15 \\
\hline Kunderd & 1930 & $\mathrm{EE}$ & B & Mrs. George W. Hay & 2.50 \\
\hline Vaughan & -.1920 & $\mathrm{EE}$ & B & MRS. H. A. CAESAR* & .10 \\
\hline Kunderd & 19 & & B & Rosy Glow **. & .20 \\
\hline Schleider & $192 £$ & $\mathrm{EE}$ & B & ROY̌AL LAVENDER** & .25 \\
\hline Prestgard & 1930 & $\mathrm{E}$ & B & Sigrid Undset & .75 \\
\hline Kinyon & 1929 & EEE & $\mathrm{C}$ & STATELY LAVENDER. & 2.00 \\
\hline Diener & .1925 & $\mathrm{EE}$ & B & W. A. SISSON & .08 \\
\hline Kunderd & 1915 & $\mathrm{E}$ & B & s Favorite* & .15 \\
\hline
\end{tabular}

\begin{tabular}{|c|c|c|}
\hline $\begin{array}{l}\text { Type } \\
\mathrm{Pl} \text {. }\end{array}$ & Season & Deficiencies \\
\hline $\begin{array}{l}\text { Pl. } \\
\text { Pl. }\end{array}$ & .......M M & $1 \ldots \ldots$ \\
\hline Pl. & $\mathrm{ML}$ & \\
\hline Pl. & 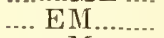 & 7,25 \\
\hline Pl. & ............... & 7......... \\
\hline Pl. & M. & \\
\hline $\mathrm{Pl}$. & .ML .... & \\
\hline Pl. &.$M \ldots \ldots$ & \\
\hline Pl. & M.. & $?$ \\
\hline $\mathrm{Pl}$. & .......... L L & 3,6 \\
\hline Pl. & ........ML ... & 21. \\
\hline Pl. & .............. & $1,17 \ldots$ \\
\hline Ruf. & .... EM ....... & \\
\hline Ruf. & .... EM ........ & $7,23 \ldots$ \\
\hline $\begin{array}{l}\text { Pl. } \\
\text { Pl. }\end{array}$ & $\ldots$ EM........ & \\
\hline $\begin{array}{l}\text { Pl. } \\
\text { Pl. }\end{array}$ & E.. EM & 229 \\
\hline $\mathrm{Pi}$ & .......ML & 23. \\
\hline Pl. & ML .... & \\
\hline Pl. & ML .... & $19,25 \ldots$ \\
\hline Ruf. & .... EM & \\
\hline $\mathrm{Pl}$. & ..... M & 10. \\
\hline Pl. & ........ML ..... & ............ \\
\hline Pl. & ML .... & \\
\hline Pl. & M........ & \\
\hline Pl. & ML ... & \\
\hline Pl. & $M$ & $?$ \\
\hline Pl. & .............. & 19 \\
\hline
\end{tabular}

LAVENDERS WITH PRONOUNCED THROAT BLOTCHES

\begin{tabular}{|c|c|}
\hline Boynton & ................. \\
\hline Salbach & \\
\hline Gelser & \\
\hline $\begin{array}{l}\text { Fischer } \\
\text { Kunderd }\end{array}$ & 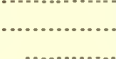 \\
\hline
\end{tabular}

EE

$\mathrm{E}$

$\mathrm{EE}$

$\mathrm{EE}$

E
CAPT. BOYNTON

Dorothy Simpson*

MARY FREY

MRS. F. C. PETERS

OCELLU'S
.05

.20

.07

.05

.50
Pl.

Ruf.

Pl.

Pl.

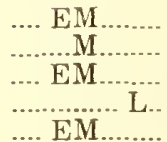

$2,16 \ldots$

1

$24 \ldots \ldots \ldots$

19,23 .

\section{CLASS 14-PURPLES}

PURPIES OF AIL SEADES

\begin{tabular}{|c|c|}
\hline Diener & \\
\hline Pfitzer & 1926 \\
\hline zer & 192 \\
\hline Cunderd & 19 \\
\hline elser & .19 \\
\hline underd & .19 \\
\hline llis & 19 \\
\hline Heemske & 19 \\
\hline le & .19 \\
\hline & 19 \\
\hline $\mathrm{K}$ & 19 \\
\hline & 19 \\
\hline & 19 \\
\hline dor & 19 \\
\hline & 1 ? \\
\hline
\end{tabular}

$\begin{array}{ll}\mathrm{E} & \mathrm{C} \\ \mathrm{E} & \mathrm{B} \\ \mathrm{E} & \mathrm{B} \\ \mathrm{E} & \mathrm{C} \\ \mathrm{E} & \mathrm{A} \\ \mathrm{EE} & \mathrm{C} \\ \mathrm{E} & \mathrm{B} \\ \mathrm{E} & \mathrm{B} \\ \mathrm{E} & \mathrm{C} \\ \mathrm{EE} & \mathrm{B} \\ \mathrm{EE} & \mathrm{C} \\ \mathrm{E} & \mathrm{B} \\ \mathrm{E} & \mathrm{B} \\ \mathrm{E} & \mathrm{B} \\ \mathrm{EE} & \mathrm{C}\end{array}$

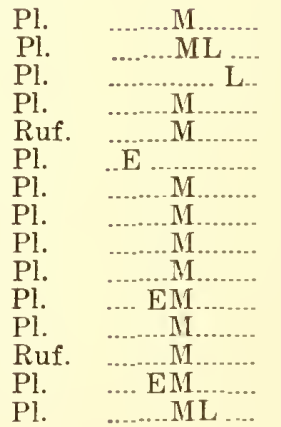

26
27

(.............

2

19

…

1..........

5,13

Pl.
Mrs. Chas. A. Stevens ........ 1.00

PAUL PFITZER*

LE OUEEN*

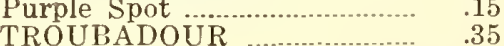




\section{Description of Lavenders}

It would be interesting to know how many of the fine lavenders we have today are in reality chance creations of hybridizers, by-products of the striving after "blues."

What is the best lavender? The consensus of opinion seems to favor Minuet, and in this we agree. There are others which can be just as beautiful, as Mary Frey, Miss Des Moines, Lavender Rose, or Berty Snow, but which fall short in reliability; and othe rs again which equal Minuet in performance, as Mrs. Peters, Jane Addams, or Royal Lavender, but can't quite touch Minuet for beauty, at least not when the last-named is at its best. Minuet thus seems to be the only one having the dual distinction of being both as beautiful as any other lavender, and also as good a performer as any other. This variety has a great future as a commercial.

Not much has been heard of A. E. Amos, but we like it on account of the large number of florets out at once and also on account of its uniqueness. It is much lighter than our other well-known lavenders. The faint throat marking is also different. It is as if a single drop of dew had spread out in the throat, dissolving all the color from it, and then drying. leaving a snow-white oval throat mark, faintly rimmed with deep lavender. Rozan (R.P.) also shows this type of marking.

Equally distinctive, but at the opposite end of the lavender color scale, is the deep-toned King Arthur. This glad strikes an entirely new note in color, being about as deep as we can conceive of lavender being without running into light red-purple. While it opens only about four florets at a time, of a somewhat triangular shape, they are of splendid size and wonderful substance. In fact King Arthur shares with Solveig the honor of having the heaviest texture yet produced in the gladiolus. I doubt whether we shall ever want heavier substance than these two glads possess. While exquisiteness is the aesthetic note we chiefly expect in lavender glads on account of the very nature of the color, the deep tone and heavy substance of $K$ ing Arthur, tho not robbing it of delicacy, combine to give it a richness that is unique in the lavender class.

A fine sort which has only this year got down to the low-priced section, is Jane Addams, a variety named after the famous American woman who this year shared the honor of winning the Nobel peace prize. Jane Addams, the glad, is also a leader.
Unlike most lavender glads which possess a silky or translucent substance, this variety has a distinctly velvety texture. It will generally open three or four six-inch florets at one time, and has been grown to over seven inches.

Other velvety lavender's are Miss Des Moines, which has unhappily proved a fickle performer; Idabelle Firestone, a most promising sort that resembles Jane Addams, except for a small throat markinglong spike: Florence, almost a light purple, to a white throat.

Dr. Moody is almost identically the color of Minuet, but has a slight throat marking less distinct than that of the latter. In Stately Lavender, we have a paler version of $M r$. Moody. It builds the same great spike.

Berty Snow is a fine light lavender with a lovely, silky sheen. The edges of the petals in this variety sometimes show a distinct rolling. Krimhilde and W. A. Sisson are light mauve-pinks of real quality. One wonders that we do not hear more of them. Lavender Rose, also a mauve-pink, is the best of the lavenders with yelicw throat. A most exquisite beauty when well gown, the soft color of the throat extending faintly into the midribs. Mrs. H. A. Caesar is smaller Minuet with a more accentuated throat marking. Royal Lavender is a good deeptoned variety with a darker throat. A fine grower. Mrs. G. W. Hay is an unusually pure-toned self with less pink in its tone than is the case with most lavenders. Buffalo Bill is an outstanding commercial resembling Byron L. Smith-a little less delicate, but a thoroly reliable performer, even in the face of adverse weather. . . . We like Kasson for its trim ruffling and charming miniature-ness. Very late, because it is a Quartinianus seedling. is stalwart Indian Summer.

We generally think of Mary Frey and Mrs. F. C. Peters together, on account of the similarity of blotch and contrastingness of season. Both are excellent, but we show our appreciation of reliability by giving Irs. Peters the place in the first hundred. At its best, however, Mary Frey is unsurpassed for sheer exquisiteness. . Dorothy Simpson is a Iilac verson of Resplendent: purple blotch on yellow throat makes it quite distinctive.... Ocellus is a little novelty with a blotch resembling the eye in a peacock feather.

\section{Description of Purples}

There are no purple glads which can be counted on to produce, consistently, spikes of a quality equal to the super-glads in other color classes, but since we must indicate the leading purples, we have placed three in the First Hundred. There would have been more, of course, harl we not transposed several "purples" to the Rose-Red class.

The greatest exhibition purple is the old Henry Ford, but not many fans care to grow it as the buds require manipulation to keep it from coming opposite-flowered.

Anna Elherius, tho now fifteen years old, has not been greatly surpassed in the interim. If this glad would only open more than three or four florets, it would be a great favorite. Color is a fine, silky, medium-light, red-purple with deeper throat. Other glads of markerl silkiness of texture are Elk- hart, of a lighter color; Graphic, and Mrs. Chas. A. Stevens, larger editions of Anna Eberius, but hardly of as fine a color; Improved Henry Ford, a narrowpetaled sort with a silver line around the edgeexceptionally silky.

Velvety sorts are: Flor Rico, a fine Purple Flor? seedling-nearly a rose-red; Mikail and Purple Spot. similar except that the latter has much more accentuated blotches of deep purple, rimmed with cream; Purple Queen, a smaller, blues, more widely-open Purple Glory; and Paul Pfitzer, a very rich, velvety red-purple self.

Troubadour, Metz, and Drama approximate Charles Dickens in color, which is a little darker and not quite so ruddy as that of Anna Eberius. Jacoba Van Beijeren is an exceptionally light purple that now and then shows surprising quality. 


\section{CLASS 15-LIGH'T VIOLETS}

SUPER GLADS $\begin{aligned} & \text { (Heary } \\ & \text { Capitals) }\end{aligned}$

ALL SHADES OF LIGHT VIOLET

\begin{tabular}{|c|c|}
\hline Originator & Year \\
\hline Errey & .1928 \\
\hline Pfitzer & 1927 \\
\hline Pfitzer & .1928 \\
\hline Frietsch & 1909 \\
\hline Hoeg, Mr & 1929 \\
\hline Pfitzer & .1930 \\
\hline Blake & 1931 \\
\hline Pfitzer & 1929 \\
\hline Errey. & 1925 \\
\hline Kinyon & 1929 \\
\hline Diener. & .1923 \\
\hline Prestgard & 1924 \\
\hline Pfitzer ... & 1926 \\
\hline Pfitzer & 1930 \\
\hline Pfitzer & .1927 \\
\hline Vaughan & 1930 \\
\hline Pfitzer ... & .1925 \\
\hline Pfitzer & .1915 \\
\hline Kunderd & 1929 \\
\hline Velthuys & .1916 \\
\hline Vaughan & .1931 \\
\hline
\end{tabular}

GROUP A GLADS $\underset{\text { Capitals) }}{\text { (Light }}$

\begin{tabular}{|c|c|c|c|c|}
\hline Size & Substance & Variety & t Pr.ice & Type \\
\hline $\mathrm{E}$ & $\mathrm{B}$ & Allawah* & .50 & $\mathrm{Pl}$. \\
\hline $\mathrm{E}$ & $\mathrm{C}$ & ALT WIEN: & 1.00 & $\mathrm{Pl}$ \\
\hline $\mathrm{EE}$ & $\mathrm{B}$ & AVE MARIA & .50 & $\mathrm{Pl}$. \\
\hline $\mathrm{E}$ & $\mathrm{C}$ & Badenia & 1.00 & $\mathrm{Pl}$. \\
\hline $\mathrm{E}$ & A & Blue Boy & 1.00 & $\mathrm{Pl}$. \\
\hline $\mathrm{E}$ & $\mathrm{B}$ & BLUE DANUBE & 5.00 & $\mathrm{Pl}$. \\
\hline $\mathrm{E}$ & $\mathrm{C}$ & BLUE MOON & 1.50 & $\mathrm{Pl}$. \\
\hline EEE & C & BLUE TRIUMPHATOR & 10.00 & $\mathrm{Pl}$. \\
\hline $\mathrm{E}$ & $\mathrm{B}$ & DAINTINESS .... & .50 & $\mathrm{Pl}$. \\
\hline $\mathrm{EE}$ & $\mathrm{C}$ & FAITH & .50 & Pl. \\
\hline $\mathrm{E}$ & $\mathrm{C}$ & Geraldine $\mathrm{Fa}$ & .10 & Pl. \\
\hline $\mathrm{E}$ & $\mathrm{C}$ & Grace E. Kimball & .25 & $\mathrm{Pl}$. \\
\hline $\mathrm{EE}$ & $\mathrm{C}$ & HEAVENLY BLUE:" & .15 & $\mathrm{Pl}$. \\
\hline $\mathrm{EE}$ & $\mathrm{C}$ & IBEIIE & 5.00 & $\mathrm{Pl}$. \\
\hline $\mathrm{E}$ & $\mathrm{C}$ & Mrs. Gertrude Pfitzer & .75 & $\mathrm{Pl}$. \\
\hline $\mathrm{E}$ & $\mathrm{C}$ & Mrs. T. J. Knudson* & 8.00 & Pl. \\
\hline $\mathrm{E}$ & $\mathrm{B}$ & MRS. VAN KONYNENBURG & .12 & Pl. \\
\hline $\mathrm{E}$ & B & Muriel $\%$ & .05 & Pl. \\
\hline $\mathrm{E}$ & $\mathrm{B}$ & PRESIDENT LINCOLN & 1.50 & Pl. \\
\hline $\mathrm{E}$ & B & Rev. Ewbank. & .10 & Pl. \\
\hline $\mathrm{EE}$ & $\mathrm{C}$ & RHAPSODY IN BLUE. & 10.00 & Pl \\
\hline
\end{tabular}

GROUP B GLADS $\underset{\text { Type) }}{\text { (Regular }}$

\section{CLASS 16-DEEP VIOLETS}

ALL SHADES OF DEEP
Pfitzer

$\begin{array}{ll}\mathrm{E} & \mathrm{B} \\ \mathrm{E} & \mathrm{B} \\ \mathrm{E} & \mathrm{B} \\ \mathrm{E} & \mathrm{B} \\ \mathrm{E} & \mathrm{B} \\ \mathrm{E} & \mathrm{B} \\ \mathrm{E} & \mathrm{B} \\ \mathrm{E} & \mathrm{B} \\ \mathrm{EE} & \mathrm{B} \\ \mathrm{E} & \mathrm{B} \\ \mathrm{E} & \mathrm{B} \\ \mathrm{E} & \mathrm{B} \\ \mathrm{E} & \mathrm{B} \\ \mathrm{E} & \mathrm{C} \\ \mathrm{E} & \mathrm{B}\end{array}$

\begin{tabular}{|c|c|}
\hline $\mathbf{A}=$ & \\
\hline Joseph Hulot & \\
\hline JE ROYAL* & 8.0 \\
\hline Lady ........... & \\
\hline hhoff's New Violet & \\
\hline CHHOFF'S VI & \\
\hline Oli & \\
\hline $\begin{array}{l}\text { OTHELLO (P) } \\
\text { PELEG } \\
\text { PELINA }\end{array}$ & \\
\hline URPLE PROGRESS* & 1. \\
\hline RAIs & 8. \\
\hline Sovereign* & \\
\hline VEILCHENBLAU & \\
\hline & \\
\hline & \\
\hline
\end{tabular}

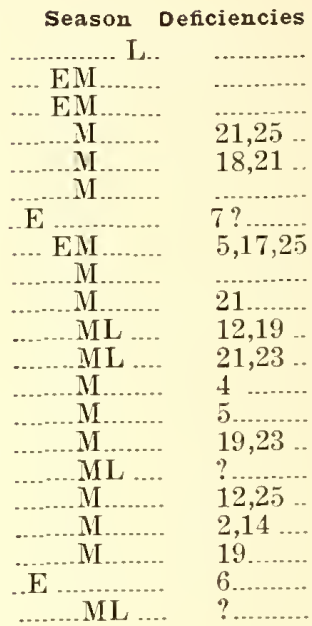

For Key to Deficiencies, see page 10 .

\section{The Secret of Growing Prize-Winning Glads}

1. Select the right varieties.

2. Plant healthy young bulbs.

3. Plant in the sunniest location possible.

4. Fertilize with thoroly decomposed animal fertilizer before planting, or after glads are up, or apply thinly several times during growing season a commercial fertilizer such as Vigoro or ammonium sulphate. Do not put directly on bulbs or plants.
5. Water thoroly in dry seasons.

6. Bloom indoors in extremely hot weather.

Glads do better than most any other flower when given no particular care; but they respond wonderfully to fine culture. As cut flowers they will do better if grown out in the open near the regetable garden than if crowded under trees or near foundations. 


\section{Description of Light Violets}

In referring to our violet glads as "blues", glad fans are not so far astray, for the "blue" glad of today would pass for real blue to the average eye. The reason is that most so-called blue flowers, when checked by Ridgeway's, are also shown to be violet, as most iris, cinerarias, etc. Nature has been very parsimonious in developing flowers of a genuine blue color, and most of them, as the forget-me-not, lobelia, and gentian, are small. Glads of a genuine blue shade have been produced, but thus far none has propagated or had healthy enough bulbs to warrant introduction. But improvement has been so rapid in this color section, that the glad fan can easily maintain a mood of high anticipation as to what the future may bring forth.

The paler section of the light "blue" class is considered by many to be too light. Blue Trinmpha. tor, is probably the lightest of all-and also the larg. est. This glad has been something of a disappointment, both on account of its paleness of color and on account of its inability to perform in our hot seasons. It is one of those things which really need to bloom out in a cool fog to be at their best. The ideal way to grow it would be to give it good culture, and then when the spike begins to show, construct a small cheesecloth enclosure around it. This would insure a cooler and more humid atmosphere which would result in a good spike and finer color. The finest "blue" glads we have ever seen were some of Pfitzer's varieties grown this way by Arthur C. Koerner. The color seems much richer, purer, and even bluer, than when the same variety is grown out in the open.
Heavenly Blue, which will throw a fine spike. may prove the most satisfactory of the pale violets. We like Rhapsody in Blue for its rich velvety purpleviolet blotch, which $i$ s the most marked blotch among the blues. The main color is a pale silvery blue, like a hazy sky on a summer afternoon. Faith is very similar to Hearenly Blue, but is less susceptible to farling.

Ave Maria, with its slightly deeper color, is our prime favorite among all the light blues. It will open eight or ten four-inch florets at one time. The color is a medium shade about half-way between that of Heavenly Blue and Veilchenblau. The throat marking resembles that of $L r$. Bennett-a darker sanding with a white spearhead in the center, a marking also found in Wimet and other glads of good performance.

Libelle offers something new in color-a clear shale slightly lighter than Ave Murie. The flowers are large and bell-shaped. Blue Danube is a stronger grower but not so distinct in color. Nllowah is a robust grower, somewhat similar to $A$ ie Maria. N/t Wien, of a fine clear shade, should be better known. Blue Moon has wonderful colos-clear and unflecked _-, but doesn't look like an ideal performer. Blue Boy is one of the nearest to true blue that we have: tho there is about 20' of grey in its make-up, there is relatively little red. I'resident Lincoln is valuable for its unique throat blotch, which reminds one of Ocellus (L.) Muriel is still the best of the inexpensive light blues, and when well grown, can still win on the show table.

\section{Description of Deep Violets}

Pelegrina is easily our favorite among the leep violets. Seen at close range, it has all the sheen of dark blue velvet. It is an improvement upon Aida in size and number of florets open. It is also both bluer and darker, and has a violet insteal of a purple throat as is the case with Aille.

Most blues, upon close inspection, are seen to be made up of two or three slightly different shades, closely interflecked. This is not true of Kunderd's l'urple I'rogress, which has the clearest color of all the violets. It has small velvety florets with many. open at once, and might be called a greatly improved Bireron Hulot.

Another good blue from Ptitzer is ()thello, which ntrikes us as being nearly the equal of A irla. Coloring is very similar, but othello has a more willowy spike. Kirchhoff's Violet is still worth while. Wideopen floret and fine placement make this valuable to the hybridizer.

Veilchenblau is the standard medium-rleep "blue". Well-grown, it is certainly fine. Tho not as tall as Rosia Raisa, the color is better, and the throat markings: more distinct.

of the new "blues" which Vaughan has come out with recently, we like Blue Royale about as well as any. The color on the leilchenblan order. It is one of our bluest "blues."

Sovereign is an improved Buron Hulot-a sport of it, I believe. Wrdgewood and Kirchhoff's Nen Violet have a little more of a purple tone. Haron Joseph Hulot. which was the first blue glad ever introduced, is the oldest variety listed in our catalog. 


\section{CLASS 17-SMOKIES, Etc.}

\section{SUPER GLADS $\begin{gathered}\text { (Heary } \\ \text { capitals) }\end{gathered}$} SMOKY REDS

\begin{tabular}{|c|c|}
\hline riginator & \\
\hline Brunelet & \\
\hline Lemoine & \\
\hline Mair ..... & \\
\hline Goodrich & \\
\hline Kunderd & \\
\hline Lemoine & \\
\hline moine & \\
\hline Childs & \\
\hline Kunderd & \\
\hline Salbach & \\
\hline Hutt .. & \\
\hline Mair & \\
\hline Prest & 1 \\
\hline 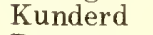 & \\
\hline oney & \\
\hline
\end{tabular}

$\begin{array}{lc}\text { size } & \text { sabstance } \\ \text { EE } & \text { B } \\ \text { EEE } & \text { B } \\ \text { EEE } & \text { C } \\ \text { EE } & \text { B } \\ \text { EE } & \text { A } \\ \text { EE } & \text { B } \\ \text { EEE } & \text { B } \\ \text { EE } & \text { B } \\ \text { E } & \text { B } \\ \text { EE } & \text { B } \\ \text { E } & \text { A } \\ \text { EE } & \text { B } \\ \text { E } & \text { B } \\ \text { E } & \text { B } \\ \text { EE } & \text { B }\end{array}$

GROUP B GLADS $\underset{\substack{\text { (Regular } \\ \text { Type) }}}{\text { Gpula }}$

\section{SMOKY PINKS}

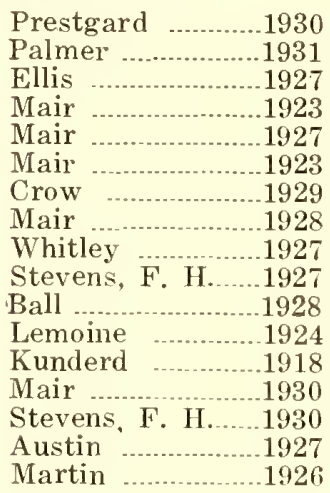

$\begin{array}{ll}\text { EE } & \text { B } \\ \text { EEE } & \text { B } \\ \text { E } & \text { B } \\ \text { EE } & \text { C } \\ \text { EE } & \text { B } \\ \text { EE } & \text { C } \\ \text { EE } & \text { B } \\ \text { EEE } & \text { B } \\ \text { EE } & \text { B } \\ \text { EEE } & \text { B } \\ \text { EEE } & \text { B } \\ \text { EE } & \text { B } \\ \text { E } & \text { B } \\ \text { EE } & \text { B } \\ \text { E } & \text { C } \\ \text { EE } & \text { B } \\ \text { EEE } & \text { C }\end{array}$

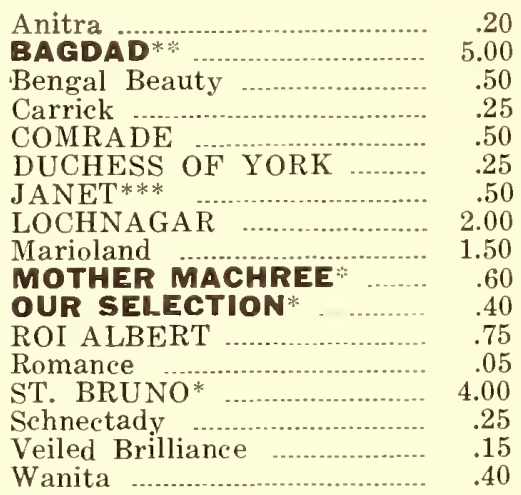

Pl.
Pl.
Pl.
Pl.
Pl.
Pl.
Ruf.
Pl.
Pl.
Pl.
Pl.
Pl.
Pl.
Pl.
Pl.
Pl.
Pl.

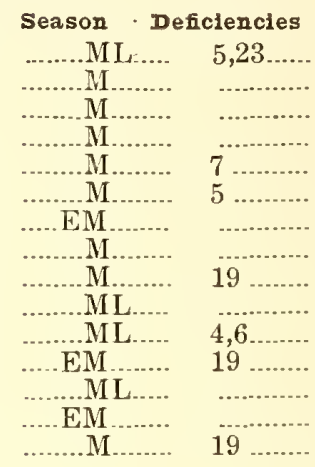

SMOKY IAVENDERS AND PURPLES

\begin{tabular}{|c|c|c|}
\hline Bride & .1927 & EE \\
\hline Pfitzer & 1929 & $\mathrm{EE}$ \\
\hline Errey & 1925 & $\mathrm{EEE}$ \\
\hline Prestgald & 1930 & $\mathrm{EE}$ \\
\hline
\end{tabular}

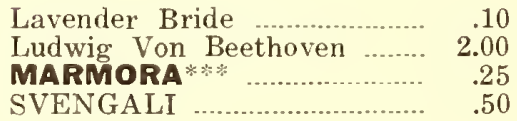

Pl.
Pl.
Pl.
Pl.
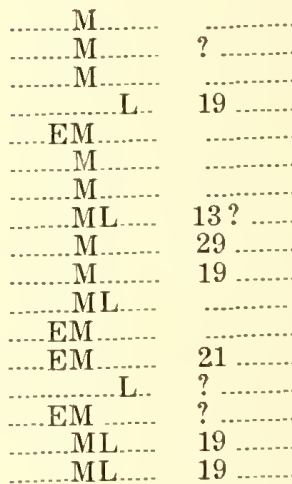

\section{SMOKY ORANGES}

Kunderd ............1925

Langlois ............192

$\mathrm{E}$

COPPER BRONZE*

Senorita (L)

.05

Pl.

Pl.
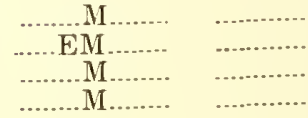

MISCELIANEOUS NOVEITIES

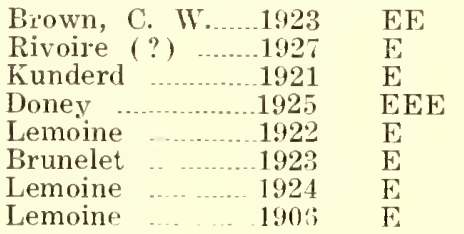

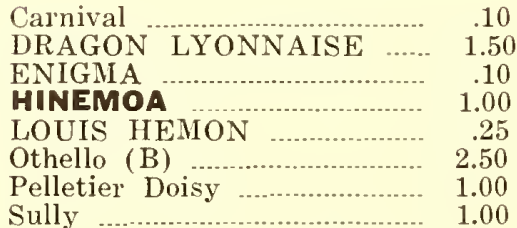

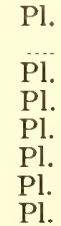

19 10,12

$21,23 \ldots$

21,23

For Key ta Deficiencies, see page 10.

Do not underestimate the value of Group A and Group B glads. Many of them are real beauties, and some of them approach the First Hundred in quality. They are of real importance in adding variety to any collection.

Varieties not priced in this catalog await government release in the fall of 1932 .

For prices of bulbs in all sizes and quantities, see the complete price schedule on inside back cover of this catalog. Bulblet prices will be found on page 32 .

No. 2 or No. 3 bulbs will frequently produce practically as fine bloom as No. 1 bulbs, tho varieties differ in this respect. Unless one has a particular reason for buying only No. 1's, we generally advise dividing one's expenditure among the first three sizes as a means of getting the most gladiolus pleasure for the money. 


\section{Description of Smokies, etc.}

The smokies represent a color group almost peculiar to the gladiolus. Many fans care little for these shades; others find them among their farorites. The smokies are unquestionably growing in popularity, however, and some very fine acquisitions have recently been made in this color class.

Among the smoky reds or rose reds Emile Aubrun is probably the leader. While this glad (like Marmora) responds to irrigation, it will always give a good spike and when watered sufficiently the result will be magnificent. Color is a dusky rose red with a clear ruby glow in the throat. Eight or nine round, five and one-half inch florets open at one time. Paul Cambon is very similar but lacks the throat marking and has more pointed petals. . . To continue the French offerings, Colbert may be described as a red edged blue, Pasteur as a ruby red with darker throat -only slightly smoky.

October will open three or four enormous florets of the heaviest bark-like substance. Color is a deep autumnal red, like a moody autumn sunset. Saraband is a smoky rose-red or red-purple with a small, sharp throat marking of cream. When the red of this flower takes on a r:ch, velvety flecking, it is a glad of truly Oriental splendor.

Field Marshall is a silky sort with many mediumsized florets open at a time. Sultan-a dusky red. Tiger and Prince of India are striped sorts-the latter a grey uniquely striped red-quite variable in color as is true of many of the smokies. Red Copper is also a tigerish looking variety. Smoky-a solid, bronzy, dusky red. Tutanekai-a warmer, lighter Hinemou. We hardly know how strongly to recommend 'Terra Cotta. Tho not a large flower, it has a clear red-brown color different from any other met with in glads. Round florets, velvety substance.

It taxes ones ingenuity to describe these smolies. Here is Mother Machree, about the most indescribable of the mall. Sort of a blend of salmon and silver grey with just a suggestion of lavender-colors reminescent of the pink and dove sharles seen in the last moments of a sunset. Mother Machree is the daintiest of the smokies. Give it good culture if you want triple "E" size.

Bagdad reminds one of Aflame. Florets are more of the winged type than is the case with Picard!y. Color is a warm pink with a slight overcast of smokiness-no flecking. We consider this a magnificent glad.

Our Selection makes a compact spike with many round salmon-colored florets open at a time. An occasional steely flecking puts this into the smoky class. Schenectady is similar but more loosely built.
Many of Mair's finest glads fall into the smoky group. They are generally of silky texture and most of them not heavily infused with grey. Duchess of York has a fine white throat (rare in smokies) to set off its clear old rose color. Comrade, Carrick, and St. Bruno are three fine slaty salmons, the last named showing the least smokiness with us. Fine rich color. Lochmagar makes a tremendous spike but has a rather hard color. Throat fades to white.

Bengal Beauty is sort of a bricky pink with a greenish-yellow throat. Unique. Romance-salmon edged blue. Marioland-dusky old rose; velvety. Roi Albert-round velvety florets; old rose with a curiously mottled throat. Wanita-a smoky Phipps.

Janet deserves special mention. This glad scel'crly rates double " $E$ " size but has better than " $B$ " substance. Clear, velvety grey-pink with a fine ruffling that gives it lots of character. The only ruffled smoky.

Greatest of all smokies is probably Marmora, the most sensational glad ever sent out of Australia. This szedling of Emil Aubrun has the same splendid size and habits, but is a distinct lavender-grey color with a small plum-colored blur in the throat..... Some morning when you have arisen early to see what new glads have burst forth into bloom ovel night, you may find Lavender liride sparkling with a wonderful sheen. Ludwig von Beethoven-a large glad that looks a little washed in color. Svengalia dark, mysterious-looking flower.

Our brownest glads are Copper Bronze and Senorita (L.) The former has unusual winged petals. Like the bronzy-toned Breeder tulips, Copper Bronzt looks rich and distinctive when vased on dark furniture.

Most freakish of glads, and hence placed here (tho plain salmon in color) is 1)ragon Lyonnaise, the glad that tried to be a columbine. Pockets and spurs in the petals. Perhaps the same as Alowe. Carnival and Enigma are two heavily reined red novelties. Hinemoa-the most striking in color of all gladioli: deep rose flaked chocolate red, with a sharply outlined cream throat. I,ewis Hemon-a clown garbed in a parti-color of red and yellow. Othello (B)-the red, white, and blue striped glad (if you have a good imagination.) Light violet ground; perhaps the most definitely striped glad. Pelletier I)oisy- "the green glad." Greenish yellow, dotted maroon. Sully-an odd novelty: white pencilled and dotted with lavender. 


\title{
CLASS 18-PRIMULINUS, Etc.
}

\author{
SUPER GLADS $\underset{\substack{\text { (Heavy } \\ \text { Capitals) }}}{\text { Suls }}$ \\ GROUP A GLADS (Light \\ GROUP B GLADS $\underset{\text { Type) }}{\text { (Regular }}$
}

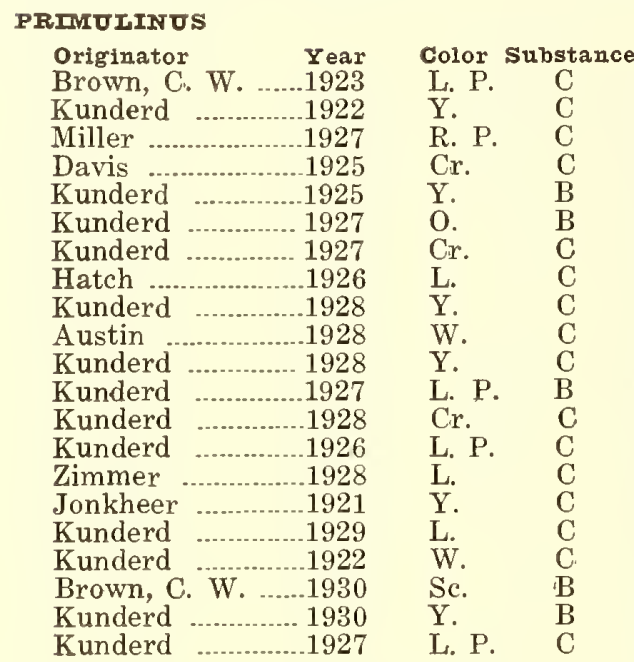

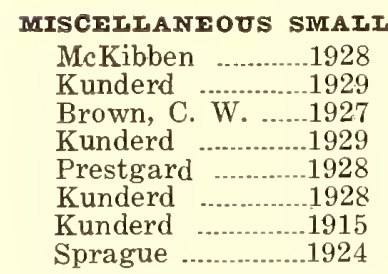

\section{TYPES}

$\begin{array}{ll}\text { R. } & \text { B } \\ \text { Sc. } & \text { B } \\ \text { Cr. } & \text { C } \\ \text { Cr. } & \text { C } \\ \text { S. P. } & \text { A } \\ \text { Y. } & \text { A } \\ \text { Sc. } & \text { B } \\ \text { L. } & \text { C }\end{array}$

\begin{tabular}{|c|c|}
\hline Uni & \\
\hline $\begin{array}{l}\text { NATE LAURE } \\
\text { utterboy* }\end{array}$ & \\
\hline $\begin{array}{l}\text { Butterboy* } \\
\text { Cara Mia* }\end{array}$ & .08 \\
\hline ara Mia* & \\
\hline enessee & .0 \\
\hline DEN FRILLS** & .0 \\
\hline Iden Orange ${ }^{*} \ldots . . . . .$. & .20 \\
\hline OOSIER PEARL & \\
\hline JANE GREY & \\
\hline ELODY & 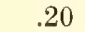 \\
\hline Imogene* & . \\
\hline lia & .20 \\
\hline CALVINCOOLIDGE** & .12 \\
\hline CLINE & .1 \\
\hline PATRICIA CARTER & .1 \\
\hline QUEEN OF BREMEN* & 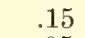 \\
\hline OUVENIR*** & .0 \\
\hline & .20 \\
\hline JHITE BUTTERFLY* & .0 \\
\hline Will Scarlet & .2 \\
\hline LLOW FRILLS & \\
\hline & \\
\hline
\end{tabular}

Type

Season Deficiencies Pl.

Ruf.

Pl.

Ruf.

Pl.

$\mathrm{Pl}$.

Pl.

Pl.

Ruf.

Pl.

Ruf.

$\mathrm{Pl}$.

Pl.

Ruf.

Pl.

Pl.

Pl.

Ruf.

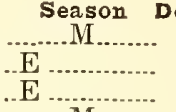

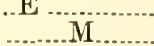

E

E ...........................

.E .............

.... EM ......

.... EM........

.... EM

EM

E

$\mathrm{E}$

.. E

Ruf.

E .

ZONA*

10

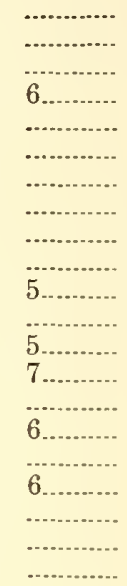

CAPTAIN KIDD

FIRE TORCH

.50

25

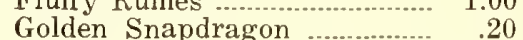

Honeydew $\quad .10$

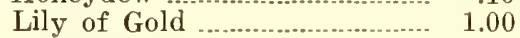

Snapdragon $\quad .15$

The Orchid .............................. .10
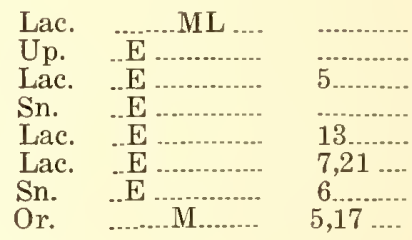

For Key to Deficiencies, see page 10.

\section{Description of Primulinus, Etc.}

Seen in the single spike or in three, as vased for the show table, these graceful little glads are quite outdazzled by their giant brethren; but viewed in a complete bouquet-which is the only way prims should ever be judged-they immediately reveal their true beauty and importance.

Among the pinks Mrs. Calvin Coolidge is perhaps the favorite today. The purest tone of soft, warm pink, blending to a rich cream throat, plus a very dainty frilling, create an effect hardly to be improved upon. Patricia Carter is an exquisite soft shade fading to an unblemished white throat. Annie Laurie is a cooler pink with a very winsome ruffling. Less well-known, but unique in one respect is Zona. Generally similar to Mrs. Coolidge, it has, added to the shadow in the upper throat, extremely abbreviated blotches on the lower petals which complete a perfect circle in the throat, giving each floret a round dark eye.

Among the yellows, Golden Frills with its heavy substance and pronounced frilling can make an exceedingly rich bouquet. If you have not grown this variety in sufficient quantity to enjoy a really lavish vase of it, you will be surprised at the effect. Souvenir, a fine, clear, silky yellow is still going strong. Pale Butterboy is interesting for its naive attempt at hooding. Scarlet-tipped Melody is unique. Mongolia_an unusually deep yellow; Golden Orange -just what the name implies.
Hoosier Pearl baffles description: its pale flesh color blends to a cream on the lower petals, grows deeper into a yellow, finally turns into a tiny blur of orange that glows like a spark deep in the throat. Pasteline is a long-petaled relative of the above: cream to a yellow throat. Genessee - a charming silky cream.

White Butterfly can produce wonderful spikes with four or five little butterfly-like florets with cream throats perched on the stem. Milady Imogene is more compact-a nicely ruffled sort.

Varro-a quaint little veined flower of a rosy lavender hùe.

We are not yet sold on the laciniated sorts, but believe that they represent the beginning of a valuable decorative type. Most of them do not open widely enough. Capt. Kidd is the best we have seen: a really wide-open little flower. Fluffy Ruffles is also well open, but has poor substance. Honey Dew is a rich apricot color. Lily of Gold has not fulfilled expectations.

Like Dragon Lyonnaise, Snapdragon (red and yellow) and Golden Snapdragon (yellow and white) attest the mutability of floral types. Fire Torch is a tiny sort with round red florets that grow all around the small wiry stem. In centerpieces, these little uprights are unique. The Orchid has long frilled petals. 


\section{Description of Oranges}

(Continued from page 13.)

Dearborn is more outstanding for size than for beauty. It generally opens in a single row six florets which are huge without being fully open. The edges of the petals show some rolling, as is the case with Nancy Hanks. Size will make it a winner on the show table.

Mexican Fire Opal and Senorita are rich light oranges with long finger-like petals. California-a robust orange-salmon that makes a tall spike. Ifonte Carlo also shows plenty of pink in its make-up. We like this one for its warm, soft tone.

La Paloma looks like a cross between Dr. Bennett and Souvenir. Ethelyn and Orange Queen are two orange-yellows beloved of florists. The latter is ideal for cutting. King of Oranges has about the richest true orange color. Very silky. Mandarin has a pure yellow throat, unblemished by the streakiness seen in the seedling of Alice Tiplady. Gay Hussar and Radiant Orange are similar and both good. The slight scarlet-on-yellow throat markings are not unattractive.

\section{Description of Cream, Buff, and Flesh Varieties \\ (Continued from page 15.)}

perfection. Wm. Kent varies in purity of color, but at its best it is practically the equal of Queen Mary. Its color is deeper and warmer, and its ruffling more of a frilling. A plain-petaled $W m$. Kent that can be glorious when well-grown, is Rippling Waters. Amity - a smaller and paler $W m$. Kent purer in tone than A. B. Kunderd. Cream Cups is a trifle deeper than Anna Mae, but otherwise they are quite similar: flesh with a large cream throat, florets waxy, cup-like, and recurved.

Bijou-ruffled yellow with a blending of plum at the tips, producing a novel russet effect. Flosellaa perfectly blissful tone of creamy pink prevails in this flower. This variety won an Award of Merit in England.

\section{Description of Pure-Pinks}

(Continued from page 17.)

Fine clear pink with white midribs. Long petals give it a winged effect. Laidley is a beautiful whitethroated sort with just a touch of red at the base of the vetals. Resembles Wm. Cuthbertson (I.P.)

Everyborly ought to get a thrill out of growing a glad called Prosperity, and happily there is oneone of our best commercial pinks. If you are not previously aware of the fact, it is only fair to say that Prosperity is the original name of Louvain. The season seemed most appropriate for a return to the older name.

\section{Description of Salmon-Pinks}

(Continued from page 19.)

teristics of Emile Aubmun, the pollen parent; in color, $95 \%$ of the tone of Apricot Glow. The smokiness of Emile Aubmen has vanished to an almost imperceptible silvery mist which overlays the warm apricot pink like the blush on blue grapes. We are very strong for Picardy and consider it one of the finest glads thus far produced. Even during the past dry season it produced long, straight spikes. Unless unexpected faults develop, which seems unlikely, it promises to be our leading commercial pink. This glad is such a strong grower, frequently blooming even from bulblets, that no fan can afford to postpone any longer having it in his garden.

Angel's Dream is a cool-weather glad of great beauty. The silky florets of purest warm light pink are unusually rose-like and can be made into especially fine tip bouquets. Apricot Glow and Gloriana are more similar than we had realized; both are lovely apricot-salmons. In color, Creatore is quite different from others in this class. It is about as rich a shade as we have in glads: a resplendent vermilion-salmon that is just enough lighter than the salmon-scarlet of Pfitzer's Triumph to put it in the Salmon-Pink class. It has a frosted, velvety texture. Creatore has given us some of the finest spikes we have ever grown, but we'll admit that it doesn't do this every year. Try giving this glad extra fine culture. .... Blenn is a larger, lighter Gladdie Boy of pronounced butterfly form; yellow-throated. Sunshine Girl is Richard Diener, turned P.G.

We tried to persuade Mr. Gove to let us list Wasaga, the beautiful apricot seedling that won the First Class Certificate in the P. G. class at Cleveland, but he felt obliged to make us wait another year. However, we couldn't forbear to tell you how good it looks, so it appears in our First Hundred, tho you will have to buy your stock of it from Mr. Gove. iVasaga is not a large glad, but is one of the most beautiful we have ever seen. Color is a pure apricot, with more yellow than pink in its compositiona solid color way into the throat. Florets are flat and plain-petaled, except for a wonderfully even frilling at the extreme edge, which is one of the finest features of this flower. Wasagu has about it the delicate air of perfection.

Another 1932 introduction of importance is Mildred Louise. "This glad is slightly pinker than Picurdy and of different form, being more widely open. In size it is almost triple "E". We consider Mildred Louise much more beautiful than Giant Nymph and finer than Betty. Nuthall, tho perhaps it may lag a trifle behind these two stalwarts as a commercial. After seeing Mildred Lonise at the Michigan Show (where it won first in the seedling division), we visited Mr. Wentworth's gardens and noted that it was a very vigorous grower and a consistent producer of good spikes. Under artificial light this variety is as fine as anything we have ever seen, being an unusually soft, glowing color. Tho I do not believe that Mildred Louise has quite the future as a commercial that Picurdy has, I think it is sufficiently different to be really valuable and that it will become widely popular among the fans. This variety is a fine propagator. In season it may be a week earlie1 than I'icardy.

\section{Description of Rose Reds}

(Continued from page 23.)

Purple Victory trailed into this color class with Purplc Glory. It is a bit lighter and perhaps contains $1 \%$ more violet, but is otherwise very similar. Fayolle has a hint of smokiness, and a throat mark dimly reminiscent of Rouget De Lisle. W. G. Hatfield opens an abundance of well-faced round florets. lamesses is a very shaggy fellow. Some fans consider it a wonder, but most of them seem to view it primarily as a hybridizer's glad. 


\section{Varieties to be Reported on Next Year}

crarieties listed in this supplementary section comprise ehoth" 1931 or 193:2 introductions or recent foreign offerings not yet acelimitized surficiently to allow us to pas's a liair judgment. A few older domestic rarieties of reputed merit which the hatre presiously overlnoked in our testing are also

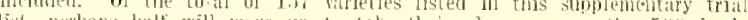
list, perhaps half will move up to take theid places among the 500 leatling varieties, Perhaps ten or twenty will win places in the First IIumbel.)

Class 1-Dark Recl Varieties

Class 2-Red Varieties

A.solit (Prestgar(-Browin)

('urminea (Mair)

Dorotlig Dow (Gitre)

lireflime (Brown)

Class 3-Scarlets

Al'magna II (Minir)

Carclinal Lueou (lemoine)

Ceckl (Mlair

Centenaire (Lemoinc)

V'Altagnan (Lemoine)

1). Buclan (Arîr

Florimel (Gilres:)

Frilled Champion (Boozen)

General Masiste (lemoine)

General Maturin (Lemoine)

(iuardsman (Crow)

Class 4-Oranges

Dorotly Dell (Carpenter)

Class 5-Yellows

Anglior (Lemoine)

Clarion (Crow)

Ensemble (Stevers, I. II.)

Class 6-Creams

lsuntleigh (Gilrey)

Dunia (l'almer)

Joan (Allatil)

Mugna Blancis (Salbach)

Class 7-Whites

Albatruss (Mlail)

loratrit (Doney)

Avalasclue (Allan)

Franziskin (Graetz)

Ivanhoe (Mair

Joan of Arc (Gilrey?

Class 9-Salinon-Pinles

teastia (Pitmer)

Ippeal (Gelser)

Comelot (Errey)

Carolia (Gilrey)

Constance (Evrey)

Corangamite (Eirey)

Dame Massey (Allam)

Hora Gill (Austin)

(badys (Marr)

lleal (Hair)

J. S. Bacl (Pfitzer)

Jenn Phyllis (Carpenter)

Joyful (Crow)

Leinder (Errey)

Class 10-Light-Pinls

Cassandra (Errey

Cluristine (Mair)

Coronation (Palmer)

Debonair (Palmer)

Florence Hubler (Austin

Goorgette (Kingsley)

lonor (Mair)

Class 11-Rose-Pinks

Ayrshire (Mair)

Bird of Paradise (Crites)

Eula Terry (Bonisteel)

liampden (Errey)

IIilda (Mair)

Class 12-Rose-Reds

Benediet (Crow)

liyle (Mair)

Class 13-Iavenders

A. H. Woodfull (Frrey)

Amazon (Gilrey)

Atlantide (Lemoine

Berty Mair (Mair)

Bugler (Sterens, F, H.)

Director (Clow)

Class 14-Purples

David Fischer (Fischer)

Class 15-Iight Violets

Bella Donna (Pfitzer)

Class 17-Smokies, etc.

Barbara Phillips (Gilrey)

Bullfinch (Mair)

Corydon (Austin)

Durban (Mair)

Gertrude Grey (Mlair)

Gertude Gres

John Hill (Mair)

Le Habitant (Cousin)
Mahogany (Mitir)

Miasstsoit (Brown)

li. I. Mair (Mair)

ILeathifield (brrey)

llelmsilale (Eires)

LaCrosse (Gilrey)

unciler (Errey)

Luxembur: (Vilmorin)

Pimpermel (Mritir)

Rel plipps (lairiras)

Spitline (Minir)

'rip-Top (Pfitzr)

Wimatal (Eirey)

wendouree (bynons)

Lucien Guitly (Lemoinc)

Gitce of llesten (I'bitzer)

Golden Cup (Palmure)

Otto Carmiclialel (Kunderi)

Newington (Wcbb)

Rose Carun (Lenume)

Sheen (Mli:is)

Madelon (Lemoine)

Mirrion Louise (C:tpenter)

Martha Brandes (Lomune)

Millimajd (Gilrey

liufled snow (Ciilrey)

Star of Bethlehom (1'fitzor?

Vierge Lorraine (l, (moine)

lisbeth (E:rey)

Miutarili (Dumey

Miss F. W. Wiltard (Faral

Mist Greeley (briggss)

Morongo (Errey)

Hrs. E. Sehumatcher (Paimen'

Mrs. Fimie (Mlair)

IIs. W'Ititlaw (Minir)

Rispture (Palmer)

Sieestern (Phtzur)

Sussex (Errey)

Sylvan Belle (Morrison)

Hyacinth (Gilrey)

Merle Morris (Gilley)

Pink Pearl (Gilrey)

Sea Shell (Groft ;

Sweetheart (Alliemivlc)

Vincennes (Lenroiue)

Jean Van Werth (Grietz)

Lovely (Mair)

Nelly (Mair)

Rosa Bella (K. \& .M.)

Vendome (Vilmorin)

Red Pirate (Gelser)

Etruria (Erréy)

Gertrade Swenson (Swenson)

Iris Phillips (Phillips

Lady Van Horn (Ginff)

Mrs. II. H. Giroft (Groft)

Pallas (Errey)

Douglas Mason (Whitley)

Violet (Mair)

Lighthouse (Gilres)

Molly Douglas (Douglats)

lloondara (Errecy)

Paisley (Austin

Ridean (Palmer)
Rosella Amos (Milir)

'T'ewhaki (Doney)
St. Cuthbert (Mlitir)

I'rince Charming (Symons)

Roscoe Huft (Kitanderd)

\section{Bulblet Price List}

(For price schedule for bulbs, see inside of back cover.) $20 \mathrm{c}$ per package for all varieties listed in this catalo at a unit price of under $\$ 2.00$

$\$ 1.00$ per package for all varieties listed at a unit price of $\$ 2.011$ or over.

Quantity in each package will vary from one bulblel to several hundred, depending on the rajity of the variety. All packages will be good value. Bulblets of "Bargain Collections for 1932"). Bulblets of Hercules are $\$ 2.50$ each No bulblets will be sold of Solveig. Mildred Iouise, or Margaret Fulton. We will meet the prices of other growers on bulblets.

The following varieties may be had in larger quantities. Pints at the quart rate. Write for prices by the peck. The degree of commercial melit possessed by these varieties, as indicated previously in our catalog. by" asterislis, is repeated here.

\begin{tabular}{|c|c|c|}
\hline variety & Per 1000 & $\mathbf{P e r} \mathbf{Q t}$ \\
\hline Aflame:s: & $\$ 2.00$ & $\$ 10.00$ \\
\hline Aiclat & 7.00 & 18.0 \\
\hline Apricot Glow & 1.00 & 3.0 \\
\hline Ave IIaria & 18.00 & 50.0 \\
\hline & 2.50 & \\
\hline Betty INutlanll心 & 2.50 & 10. \\
\hline Carolus Clusiustio & 1.00 & \\
\hline Catherine Coleman & 1.25 & \\
\hline Charles Dickens: & 1.00 & 5.0 \\
\hline Corypliee ........................ & 10.00 & 40.0 \\
\hline Crinkles & .75 & \\
\hline Decoration ${ }^{*} \xi_{4}$ & 10.00 & 40.0 \\
\hline Di: F. E. Bennett & .80 & 2.00 \\
\hline $\begin{array}{l}\text { Dr. Thocdy } \\
\text { Dr. Nelson Sliook }\end{array}$ & $\begin{array}{r}4.00 \\
-\quad 60\end{array}$ & 10.00 \\
\hline Dr. Nelson Sliook ........ & & \\
\hline $\begin{array}{l}\text { E. I. Parrington } \\
\text { Emile Aubrun }\end{array}$ & $\begin{array}{r}8.00 \\
.80\end{array}$ & 24. \\
\hline 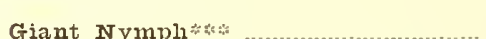 & & \\
\hline $\begin{array}{l}\text { Giant Nymplis } \\
\text { Gloriana }\end{array}$ & .50 & \\
\hline Golden Dream & .80 & 2.5 \\
\hline Golden Frills & .80 & 3.0 \\
\hline Heavenly Blue & 2.50 & 10.00 \\
\hline Jane Acldams & 3.50 & 12.00 \\
\hline Jenny Iind 将: & .80 & 2.5 \\
\hline & 8.00 & 20.0 \\
\hline Jonklieer Van Tets & 36.00 & \\
\hline $\begin{array}{l}\text { In Paloma } \\
\text { Loyalty }\end{array}$ & 8.00 & 24.00 \\
\hline $\begin{array}{l}\text { Loyalty } \\
\text { IMaclam MI. Sully }\end{array}$ & 10.00 & 35.00 \\
\hline $\begin{array}{l}\text { IIaclam M. Sully } \\
\text { Marmorat }\end{array}$ & 4.00 & 12.00 \\
\hline $\begin{array}{l}\text { Marmorat } \\
\text { MIarnia }\end{array}$ & 3.00 & 9.00 \\
\hline $\begin{array}{l}\text { Marnia } \\
\text { Mary Frey" }\end{array}$ & .75 & 1.50 \\
\hline $\begin{array}{l}\text { Mary Frey } \\
\text { Minuet }\end{array}$ & $\begin{array}{l}2.00 \\
3.00\end{array}$ & 6.00 \\
\hline $\begin{array}{l}\text { IVinuet } \\
\text { IMiss Joy }\end{array}$ & $\begin{array}{l}3.00 \\
6.00\end{array}$ & $\begin{array}{l}10.00 \\
20.00\end{array}$ \\
\hline Mother Macliree* & 10.00 & \\
\hline Mrs. IIornberger & .80 & 2.00 \\
\hline Mrs. F. C. Peters & .80 & 1.50 \\
\hline Mrs. J. I. Walsh: ... & 2.00 & \\
\hline 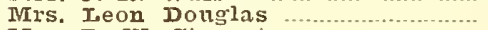 & .80 & 2.00 \\
\hline Mrs. P. W. Sissont: & .80 & 1.50 \\
\hline Olive Goodrich $\%$ & 1.00 & 2.50 \\
\hline Oraflame & 2.00 & 5.00 \\
\hline Orange Queen $* * *$ & .75 & 1.50 \\
\hline Orange Woncler & 8.00 & 24.00 \\
\hline Our Selection & 18.00 & $\cdots$ \\
\hline Patricia Carter & 8.00 & 25.00 \\
\hline Paul Pfitzer & 7.00 & 20.00 \\
\hline Pearl of California & 2.00 & 5.00 \\
\hline Pride of Portland & 7.50 & 3000 \\
\hline Pride of wanakah & .75 & 1.50 \\
\hline Pfitzer's Triumpl .. & 5.00 & 1600 \\
\hline Purple Glory & 1.50 & 2.50 \\
\hline Purple Queen" & 1.50 & 3.25 \\
\hline Red Fire & .75 & 2.00 \\
\hline Rita Beck & 4.50 & 12.00 \\
\hline Spirit of St. rouis & 5.00 & 12.00 \\
\hline veilchenblau & 5.00 & 1500 \\
\hline Victor (E) & 5.00 & 20.00 \\
\hline W. H. Plipps & .80 & 2.50 \\
\hline Yvonne & 1.50 & 4.00 \\
\hline
\end{tabular}




\section{Bargain Offers for 1932}

While glad prices are so low this year that almost everything seems to fall into the bargain class, we are able to make some extra special offer's on certain varieties.

Instead of offering a great many collections, however, we are listing just two, but they ara so flexible and comprehensive as to take the place of a dozen others.

\section{COLLECTION A-SURPRISE COLLECTION.}

This is a continuation of a collection which Mr. Prestgard oftered for many vears, and which proverl very popular.

If you send us from $\$ 2.00$ to $\$ 10.00$ and allow us to make the selection for you, we guarantee to send you namerl varieties to the value of double the amount you send us. Thus, if you send us $\$ 5.00$ for Collection A it means that you will receive bulbs to a total list price of $\$ 10.00$. Everything will be labeled.

The reason we are able to make this offer is that each season finds us with a surplus of some varieties and a shortage of others. By offering this collection we a re able to equalize our stocks in the proper way. We positively do not utilize this collection to clean out stocks of inferiol varieties. It is our business policy, in filling all orders, to imagine ourselies at the receiving nnd of the transaction, and to try to fill them in a way that would bring pleasure to ourselves. With our large stocks of many of ths learling glads, we will surprise you at the quality of the varieties we can send as Collection $\mathrm{A}$.

If you wish only Decorah varieties in this collection, please specify. Otherwise we shall make no distinction as to originators in filling these orders. You may also mention one or two of your favorite colors, if you wish.

\section{COLLECTION IB-DE LUXE CAFETERIA COLLECTION.}

A cafeteria may not be a de luxe place in which to eat, but in this "make-rour-own-choice" collection, wo have certainly inclucled many of the finest glads in existence at real bargain prices.

Select any four items (all different) for $\$ 3.00$.

Select any seven items (not more than two alike) for \$5.00.

Select iny fifteen items (not more thas five alike) for $\$ 10.00$.

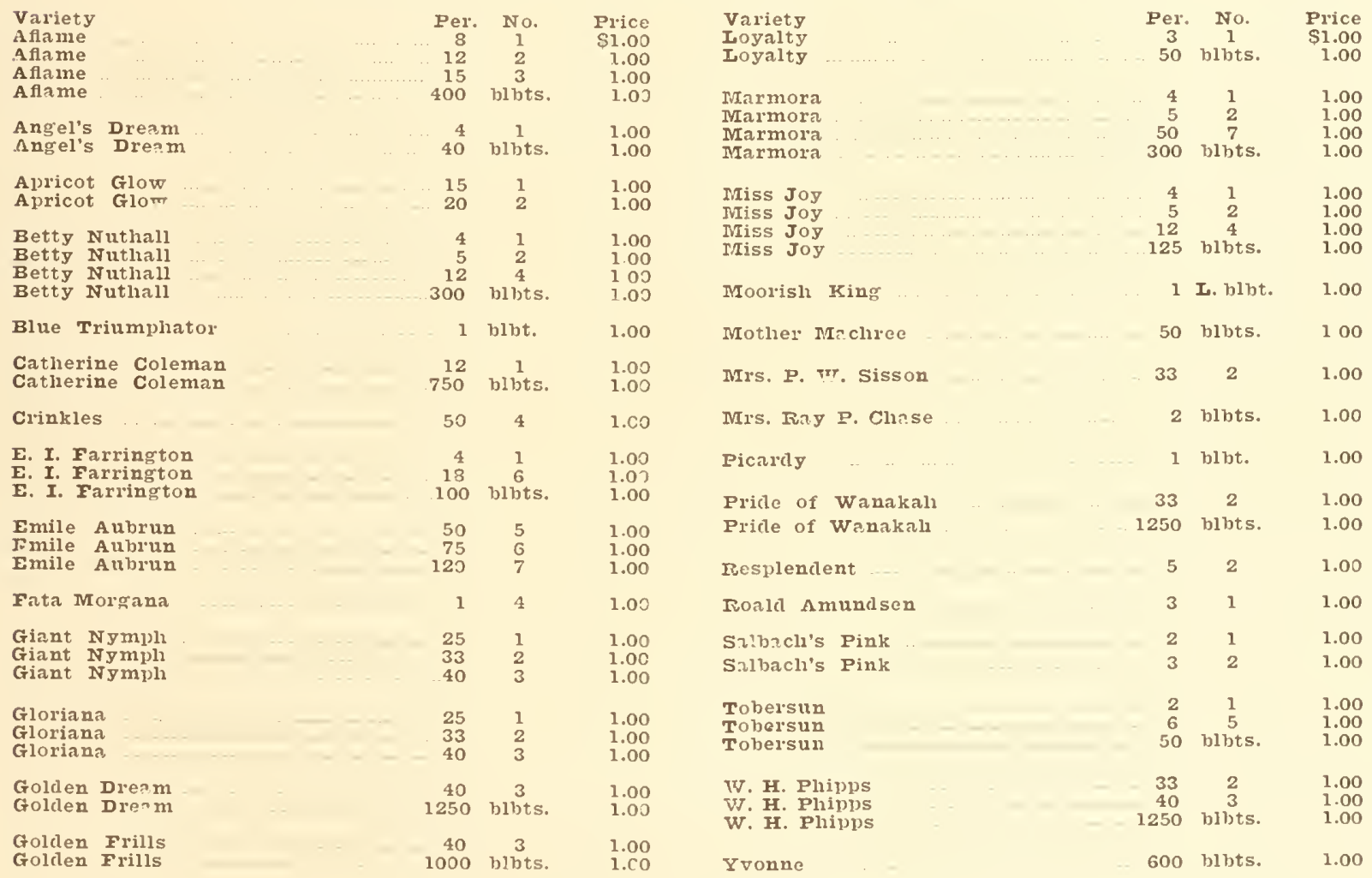

ETTHER OF THE ABOVE COI.LECTIONS MAY BE CREDITED TOWARD GETTING THE GLAD TOLUS SIIDE RULE. provirled at leasî $\$ 2.00$ of your total order is from our regular list. Every glad fan slioulel take advantage of this generous offcr.

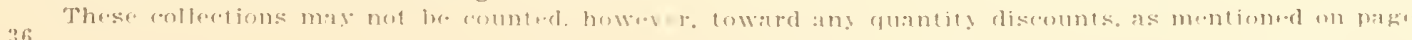

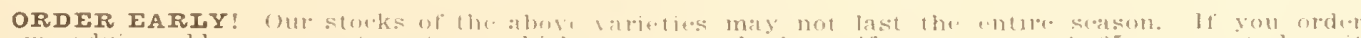

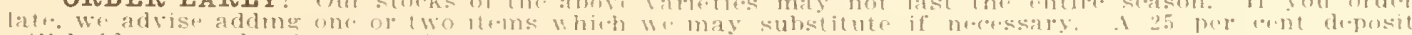
will bold your order for later shipment, if dlesired. 


\section{Alphabetical Index}

Numbers following color class notations indicate division of the color class in which the variety will be found. Absence of any number indicates that a variety will be found in the

first division of its color class.)

Variety

\section{A}

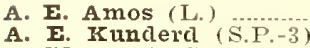

A. W. Hunt (Sc.)

A. W. Funt (Sc.)

Aflanie (Sc.-3)

Aida (D.V.)

Albania (IV.)

Alice Reid (L.P.-2)

Allawaln (L.V.)

Alplieus (S.P.-3)

Amethyst (R.P.-2)

Angel's Dream (S.P.-4)

Anna Eberius (P)

Anna Mae (Cr.-3)

Annie Iaurie (Pr.)

Annie Laurie (Pr.)

Anthony B. Kuncierd (C)

Apricot Glow

Arabia (D.R.)

\section{B}

Badenia (L.V.)

Baron Josepi Fulot (D.V.)

Baron Van Wynbergen (S.P.)

Beat All (S.P.)

Beatriz Michelena (Sc.)

Beauty Wave (Y.)

Belinde ( $\mathrm{Cr}$ )

Bengal Beauty (Sm.-2)

Berty Snow (L.)

Betty Nuthall (S.P.-2)

Bijou (Cr.-5)

Bill Sowden (R.)

Bleeding Heart (L.P.-3)

Blenn (S.P.-4)

Blue Boy (L.V.)

Blue Danube (T.V.)

Blue Moon ( L.V.)

Blue Ropale (D.V.) (L. V

Blushes of Gream (L.P.-2)

Bon Echo (L.P.)

Bobb. (R.)

Buffalo Bill (L)

Buifalo Bill (Li.)

Byron I. Smitil (I

\section{C}

Cadillac ( $\mathrm{Y}$.)

Caledonia (S.P.)

California (O.)

Canberra (Y.)

Capt. Bornton (L.-2)

Captain Kidd (Pr.-2)

Cara Mia (Pr.)

Cardinal Prince (R.)

Carmen sylva (IV.)

Carnival (Sm.-5)

Carolus clusius (S.P.)

Carrick (Sm.-2)

Catherine Coleman (S.P.)

Charles Dickens (P.)

Charles H. Fairbanks (Sc)

Charles Lindbergh (P.P.)

Chicago (Sc.)

Claade Bowers (R.R.)

Col. Chas. Iindbergh ( R.P.-2)

Colbert (Sm.)

Commander Koehl (R.)

Commodore (Sc.-2)

Comrade (Sm.-2)

Constancy (R.P.-2)

Copper Bronze (Sm.-4)

Coronado (TV.-2)

Corypliee (L.P.) -...

Cream Cups (Cr.

Crimson Glow (R.)

Crimson Glow (R.)
Unit Price Variety

$\$ 1.00$

.08
.08
.50
.15

.15

.20

.05
.50
.25

.25

1.00

1.75
.75
.50

.50
.25
.20

.20

.50

.05

.02

.05

E. C. Vick (R.R.)

Ear1 Benbow (W.-2)

Early Sunrise (S.P.)

Edith Robson (S.P.-3)

Eleonora Duse (L.P.-3)

Elizabeth Swartley (P.P.)

Elkhart (P.)

Fmblem (Sc.)

Emile Aubrun (Sm.)

Emma (S P.-3)

Enigma (Rm.-5)

Ensign Morint (Sc.)

Esme Desally (S.P.)

Esme Desain

Encine Lefebrre (R P.-2)

Evelyn Kirtland (S.P.)

\section{F}

Faith (L.V.)

Fata Morgana (S.P.-2)

Favorite (S.P.)

Fay Lanphier (S.P.)

Fern Kyle (Cr.)

Field Marshall (sm.)

Fire Torch (Pr.-2)

Flor Rico (P.)

Florence (L.)

Flurenty Ruffles (Pr.-2)

Forest Fire (Sc.)

Fort Sumter (Sc.)

Frank J. McCoy (P.P.)

Frank M. Schick (S.P.

Frederick Christ (Mr.) (L.P.)

Fuld's Favorite (L.)

\section{G}

G. J. McKay (Sc.)

Gallant I eader (P.P.)

Gay Fussar (O.-2)

Genessee ( $\mathrm{Pr}$.

George J. Joerg (S.P.)

Georgia (R.R.)

Geraldine Farrar (L.V.)

Gertrude Errey (L.P.-2)

Gettysburg (D.R.)

Giant Nympli (P.P.)

Gladdie Boy (S.P.-4)

Gladness (Sc.)

Gloriana (S.P. -4)

Gloriosa (R.-2)

Gold ( $Y$.)

Gold Eagle ( $Y$.

Golden Anniversary $(Y-2)$

Golden Climes ( $Y$.

Golden Dream (Y.)

Golden Glow ( $\mathrm{Y}$.)
E. I. Farrington $(\mathrm{Y}-3)$

Elizabeth (L.P.)

Franz Schubert (P.P.)

Giant Pearl (IW

Golden Frills (Pr.) variety

Unit Price

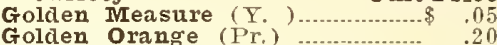

Golden Orange (Pr.) (............ $\quad .20$

Golden Snapdragon (Pr.-2) ......... 1.20

Goldfinch (Y.-3)

Gorgeous (R.R.)

Grace E. Kimball (L.V.) -........... .25

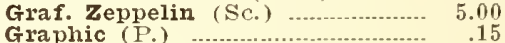

\section{$\mathrm{H}$}

Heavenly Blue (L.V.)

Frelen Foward (Cr:-2)

Felen Plipps (S.P.)

Felen Wills (IV.)

Feliosa $(Y$.

Fenry C. Goehl (W.-2)

Henry C. Pety (Sc.)

Hercules (Cr.-2)

Fernani (R.P.-2)

High Nye (L.)

Hinemoa (Sm.-5)

Fillyhock $(\mathrm{W},-2)$

Hoosier Pearl (Pr.)

I

Idamae (Cr.)

Illuminator ( $\mathrm{R}$.)

Imp. Queen of Night (D.R.) -.

Impressive (P.P.)

Improved Fenry Ford (P.)

Indian Summer (L.)

Inspiration (S.P.)

Ivernia (L.P.)

Iwa (S.P.-3)

\section{$\mathrm{J}$}

J. Horace McFarland (o.

J. Ogden Armour (S.P.-3)

Jane Addams (L.)

Jap Iady (D.V.)

Janet (SM.-2)

Jean du Taillis (S.P.-3)

Jean Tenny (R.P.)

Jenny Lind

Jcanna Hill (P.P.)

Joe Coleman (R.)

Joerg's White (IV.)

John Ramsay (S.P.)

Jonkheer Van Tets (TV.)

Jubilee (T,

Juniata (L.P.-2)

$\mathrm{K}$

Kasson (L.)

King Arthur (L.)

King George (R.-2)

King of Oranges (O.-2)

Kirchlnoff's Violet (D.V.)

Krimhilde (

K's Yellow Favorite ( $Y$.)

L

Ia couronne (Cr.-4)

Ia Paloma (O.-2)

Lady Jane Grey (Pr.)

Lady Iorene (S.P.)

Lady Macbeth

Laidlev (P.P) (Sm-3)

Iavender Bride

Lavender Delight (L.

Irvencler Rose (I

Ieviathan (L.P.) (Sm.)

Libelle (L.V.)

Lily of Gold (Pr.-2

Iittlejohn (R.P.)

Iochnagar (Sm-2)

Longfellow (P.P.)

Iorice (Sc.)

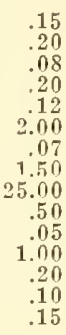

$1.5 n$
.10
.07

5.00
2.50

.05

.05

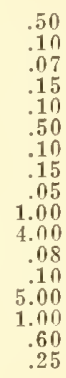

Idabelle Firestone (L.) ….......... $1.5 n$

Lotus (L.P. -4 )

.10
.07
.08

.05
5.00
1.50

50 
Variety

Louis Hemo

(Sm.-5)

Unit Price

Ludwio Von Beethoven (Sm-3)

Lustre $(R$.$) B.$

\section{M}

Madam George Boulay (IW.-2) Madam Mounet-Sully (T, -2) Madam Norena (Cr.-2)

Madam Schumann-Heink (L.)

Magnet (Y.-3)

Maid of Orleans ( $\mathrm{W},-3)$

Mammoth white (IV)

Mandarin $(0,-2)$

Marechal Fayolle (R.R.)

Margaret Fulton (S.P.)

Marie Kunderd (W.)

Marietta (S.P.-3)

Marilyn Ann (R.P.)

Marioland (Sm.-2)

Marmora (Sm.-3)

Marnla (O.)

Marolee (S. $\mathrm{P}-2$ )

Marshall Foch (S.P.

Mary Carmichael (R.P.)

Mary Elizabetlı (Cr.)

Mary Frey (L.)

Mary Jane (R.P.)

Mary Lockwood (L.P.)

Mary Marie (L.P.)

Mary O'Mine (IV.)

Maurice Fuld

Melody (Pr)

Memory of Wm. Pfitzel (IV)

Metz (P.)

Mexican Fire Opal (O.)

Mibloom (W, -2)

Mikail (P)

Milady Imogene (Pr.)

Miladed Louise (S.P.-4)

Ming To (Cr.-5)

Minuet ( $\mathrm{L}$. $)$

Miss Des Moines ( $\mathrm{L}$.

Miss Joy (L. P.- 1 )

Miss New York (L.P.)

Mona Lisa (L.)

Monarcli of the Glenn (S.P.)

Miongolia (Pr.)

Monnie (D. R.)

Monte Carlo (O).

Montenegro (D.R.)

Moorish King (D.R.)

Morocco (D.R.)

Mnther Machree (Sm.-2)

Mrs. Anna Pfitzer (Cr.)

Mrs. Calvin Conliage ( $\mathrm{Pr}$ )

Mrs. Clas. A. Stevens (F.)

Mrs. Dr. Norton (L. P.-2)

Mrs. E. A. Hamill (Y)

Mrs. E. A. Hornberger (W.)

Mrs. F. C. Peters (I - - 2)

Mrs. F. L. Karcher (Sc)

Mrs. Francis King (Sr.)

Mrs. Frank Pendleton (I, F,-3)

Mrs. George w. Hay (L.)

Mrs. Gertrude Pfitzer (L.V.

Mrs. H. A. Caesar (I,

Mrs. F. E. Bothin $(\mathrm{I}, \mathrm{P}-3)$

Mrs. H. M. Whitcomb (T, T)

Mrs. John $\mathbf{R}$. Walsh (T,,-3$)$

Mrs. Kr. Prestgard (IT

Mrs. Leo Miller (S.T.-2)

Mrs. Leon Douglas (S.T.)

Mrs. P. Wisson (

Mrs. S. A. Errey (O)

Mrs. S. A. Errey (R.P.)

Mrs. T. Rattray (R. T (I, $\mathrm{T},-2$ )

Mrs. T. E. Langford (I, $\mathrm{F},-2)$

Mrs. T. J. Knudson (L. Y, ) Muriel (I.Y.)

\section{$\mathrm{N}$}

Nancy Hanks $(0,-2)$

Ne Plus oltra (Cr.-2)

Netherland Prince (S.P.)

New Gold (Y.)

Nimrod (D.R.)

Nineteen-Ten Rose (ID

Noel Reeve (I)

Norma Talmadge ( $\mathrm{Y}$ )

\section{$\mathrm{O}$}

Obelisque ( $\mathrm{Cr}$.)

Ocellus (L.-2)
October ( $\mathrm{Sm}$.
Variety

Odalisque (II,-2)

olio state (R.P.)

olivar (D.V.)

Olive Goodriclz (L.P.12)

Oraflame $\left(\mathrm{O}_{\mathrm{S}}\right)$

Orange Fires (Sc.)

Orange Flame (Sc.)

Orange Queen (O.-2)

orange wonder (O.)

Othello (B) (Sm.-5)

Othello (P) (P)

our Selection (sm.-2)

\section{P}

Panope (S.P.)

Pasteline (Pr.)

Pasteur (Sm.) ….......

Paul Cambon (Sm.

Paul Deschanel (R.P.-2)

Paul Pfitzer (P.)

Pauline Kunderd (R. F.)

Peace (IV-2)

Pearl of California (P.T.)

Pelegrina (D, Y )

Pelletier Doisy (Sm-5)

Pfitzer's Triumpl (Sc)

Philatelia (R.R.)

Picardy (S.P.-4)

Pink Lily (R.P.)

Pink Lily (R.

Point Twain (S.T.)

President Lincoln (L.V.)

Pride of Portland (Sc.-2)

Primate $(Y,-3)$

Primrose Princess ( $Y$.)

Prince of India (sm.)

Princess Mary (L.P.-2)

Prof. Van Slogteren (L.P.)

Prosperity (P.P)

Purple Glory (R.R -2)

Purple Progress (D.V.)

Purple Oueen (P.)

Purple Suot ( $P$.

Purple Victory (R.R.)

\section{Q}

Oueen of Bremen ( $\mathrm{Pr}$.)

Queen Louise ( $\mathrm{W}$.

\section{$\mathrm{R}$}

Radiant Orange (O.-2)

Rajah (D,R.)

Ramesses (R.R.)

Red Copper ( $\mathrm{Sm}$.

Red Fire (R.)

Red Fire (R.)

Rosy Glow (I.

Red Lory (R.R.)

Red Splendor (R.)

Red Tornado (Ti)

Resplendent (L.P'-3)

Rev. Ewbank (I,V)

Rluapsody in Blue (L.I.)

Richard Diener (S.P.)

Rippling waters $(\mathrm{Cr},-3)$

Rita Beck (L.P.)

Rita Phillips (S. 'P.)

Roald Amundsen ( $R$.

Roabert the First (R.F.)

Roi Albert (Sm.-2)

Roi Albert (Sm,-2)

Romance (Sm, -2 )

Rosemarie Pfitzer (1..P,-2)

Rose Mist (R.P.-3)

Rouget De Lisle (R.)

Rozan (IR.P.)

Ruffled Gold $(Y,-3)$

\section{$\mathrm{S}$}

S. A. Kurtz (IV,-2)

Salbacll's Orcluid (R.F.)

Salbach's Pink (S.T.)

Saraband (sm.)

Scarlet Bedder (Sc.-3)

Scarlet Princeps (Sc.)

Scarlet wonder (IR.)

Sclienectady (Sm.-2)

Seafoam (IV.-3)

Senator (S.P.)
Unit Price

81.00

Senorita (L) (Sm.-4)

Senorita (S) (O.)

Shell Pink (P.I,-2)

Show Flower (R.R.-3)

Sidney Plummer ( $\mathrm{Y}$.

Sigria Undset (L.)

Smoky (Sm.)

Snapdragon (Pr.-2)

Snow Boy (II, - 2 )

Snow Glory (II.)

Solveig Fischer (P.P)

Souvenir (Pr.)

Spirit of St. Touns 10 .

Spray of Gold (T.-3)

St. Bruno ( Sm.-2)

Star Lily ( $Y$.

Stately Lavencler (L.).

Stuttgarclia (Sc.)

Sully (Sm.-5)

Sultan (CI) (Sm.)

Sunny Jim (I,P,-2)

Sunshine Girl (S P.-4)

Sunshine Glow (Sc.-3)

Sunshine Giow

Sweet Rose (R.P.-2)

\section{$\mathrm{T}$}

T. A. Weston (S.P.)

Taro (R. R.)

Terracotta (Sm.)

The Aristocrat (S. $\mathrm{P},-4$ )

The Grand Guardian ( $\mathrm{F}$.)

The Orchid (Tr,-2)

Thomas A. Edison (K) (D.P) .. 1.01

Tiger (Sm.)

Tinamba (S.P.)

Tintaldra (R.P.)

Tobersun (Y.)

Trilby (cr.-2)

Triumphator (SC)

Trudel Grotz (S.P.-3)

Trudel Grotz (S.

Twilight (Cr.-2)

\section{V}

Varrn (Pr.)

Vauglian's white (IV.)

Velled Brilliance (Sm.-2)

Velled Brilliance (Sm.-2)

Victor (Sr.-2)
Virginia Hale (I.P. -2$)$

\section{IV}

W. A. Sisson (L.)

W. H. Phipps (IIr.) (S.P.)

w. G. Hatfield (R.R.)

Wanita (Sm.-2)

Wasaga (S.P.-4)

Wedgewood (D.Y.)

White Buttertiy (Pr.)

White Kniglit (IV,-2)

white orchid (WV.-3)

white Pearl (VV.)

Will Scarlet (Pr.)

wings of the Mnining (P.P.

Wm. Booth (R.R.)

wm cuth

Wm. Kent (Cr.-3)

Wodan (D.Y.)

Wolfgang Von Gretle (sc

Wonderful (R.P.-2)

Wuertembergia (Sc,-2)

w yoming (Y.)

\section{Y}

Yellow Frills ( $\mathrm{Pr}$.)

Yellow Perfection (T.

Yellow Wonder ( $Y$.)

Youell's Favorite (L.)

Yvonne (L.P.)

\section{Z}

zona (Tr.) 


\section{Please Read Before Ordering}

We pay postage or express charges to all points in U. S. and Canada but not to oversea countries.

We ship no bulbs during December, January, and February except at special request of buyer and at his risk. At other times we guarantee safe delivery. No order accepted after May 1 and from Canada not after April 1.

TERMS:

Cash with order or before shipment. Customer's outside the U. S. are requested to remit by international money order or draft on New York or Chicago banks, made out in American money. Personal checks from foreign countries not accepted. Orders for spring delivery accepted and booked now if $25 \%$ of amount accompanies order, the balance cash before shipment or C. O. D.

\section{DISCOUNT:}

On orders of $\$ 10.00$ or over we give you $10 \%$ extra value in bulbs of your selection. Order's of $\$ 25.00$ or over, $15 \%$ extra bulbs. Order's of $\$ 50.00$ or over, $20^{\prime} ;$ extra bulbs. Orders of $\$ 100.00$ or over, $25 \%$ extra bulbs, all your selection. For large quantities write us for special rates and discount. The slide-rule is given in addition to these regular discounts, but special collections on page 33 may not be counted toward these discounts.

\section{REFERENCE:}

First National Bank or Rushford State Bank, Rushford, Minnesota.

All stock offered subject to prior sale. All orders filled with extra count and extras in proportion to the size of your order.

No orders accepted for less than $\$ 1.00$, if American, or $\$ 5.00$ if Canadian or foreign.

PLEASE DO NO'T ORDER SINGLE ITEMS FOR LESS THAN \$.10. In the case of varieties selling at $\$ .05, \$ .07, \$ .08$, please order at least two bulbs of each.

\section{BULBS:}

Our State inspectors, after examining our large stock of bulbs this fall, gave them an ANo. 1 Bill of Health. This was only natural as we have planted our glads on new ground each year and have never hesitated to discard stocks which showed traces of disease. Also, we have always treated our bulbs, as a preventative measure,- - previously with Semesan or bichloride of mercury, this year with Calogreen or bichloride. All the more expensive sorts, of which we had relatively smaller stocks, were treated with Calogreen.

Also we can offer thrip-free bulbs, as this pest has not yet appeared in this area.

So much about clean stock. The Colonial Gardens also guarantees to send out only young bulbs-high-crowned ones, if the variety somes that way, but in any case young stock.

All stock is also guaranteed to be true to name. Mistakes have occurred with us very rarely, but in case of the occasional inevitable error, we shall be glad to replace stocks together with full normal increase, or arrange otherwise, if preferred, to your entire satisfaction.

\section{A WORD ABOUT PRICES:}

The Colonial Gardens will meet the catalog prices of any of the leading growers. It is a little hard to know what turn prices will take in times like these, though we feel that our prices are already very low for the quality of stock we are offering. If you wish to give us a share of your patronage and find our prices on any varieties distinctly out of line, just fill in your order at our prices and make a note at the end of your order and we will either allow you the difference in cash or in bulbs of your choice. If you wish the latter, specify varieties that you prefer.

Acknowledgments will be sent for all orders received, but will not be itemized on orders under $\$ 5.00$ unless requested.

\section{ORDER EARLY :}

This injunction has been heard so often it seems like annual ballyhoo, but it is actually important if you want the rarer varieties, stock of which is short not only with us, but with growers all over the country.

Remember the Gladiolus Slide-Rule, which will be given free with all $\$ 5.00$ cash orders or all $\$ 1000$ orders accompanied by a $25 \%$ deposit. Note that collection items man be credited toward the Slide-Rule provided at least $\$ 2.00$ of your order is from our regular list. You may order the Slide-Rule sent at once and your bulbs held until later if you wish. 


\section{COMPLETE PRICE SCHEDULE FOR BULBS IN ALL SIZES AND QUANTITIES}

This price schedule is applicable to all of the 500 varieties listed in our catalog.

To use this schedule, just take the "Lnit Price" (for 1 No. 1 bulb) as given previously in this catalog and key it up with the same unit price as it appears in this schedule. For instance, Jane Addams is listed in the lavender color class with a unit price of $\$ .15$. To find the prices of smaller sizes or larger quantities of Jane Addams, just look for the unit price of $\$ .15$ in this price schedule. It is given in heavy figures. The prices accompany ing this figure are for Jane Addams in all sizes and quantities, and also for all other varieties having a unit price of $\$ .15$

Three or six bulbs may be had at the dozen rate, 25 at the hundred rate, 250 at the 1000 rate. Where no 1000 rate is given, 1000 may be figured at 8 times the 100 rate. Where no 100 rate is given, 100 may be figured at 8 times the dozen price. II here no dozen rate is given, it may be figured at ten times the unit price.

The following prices supersede all previous hists. ORDER EARLY. A 25\% deposit will hold your order for later shipment Please do not order any single items for less than $\$ .10$.

\begin{tabular}{|c|c|c|c|c|c|c|c|c|c|c|c|c|c|}
\hline Per & No. 1 & No. 2 & No. 3 & No. 4 & No. 6 & No. 5 & Per & No. 1 & No. 2 & No. 3 & No. 4 & No. 5 & No. 5 \\
\hline $\begin{array}{l}1 \\
3 \\
12 \\
100 \\
1000\end{array}$ & $\begin{array}{r}.05 \\
.13 \\
.50 \\
3.75 \\
30.00\end{array}$ & $\begin{array}{r}.10 \\
.40 \\
2.80 \\
24.00\end{array}$ & $\begin{array}{r}.35 \\
2.40 \\
19.00\end{array}$ & $\begin{array}{r}.25 \\
1.50 \\
14.00\end{array}$ & $\begin{array}{r}.20 \\
1.20 \\
9.00\end{array}$ & $\begin{array}{r}.15 \\
.75 \\
5.00\end{array}$ & $\begin{array}{l}1 \\
3 \\
12\end{array}$ & $\begin{array}{r}.75 \\
1.90 \\
7.50 \\
1.00\end{array}$ & $\begin{array}{r}.65 \\
1.75 \\
6.50\end{array}$ & $\begin{array}{r}.55 \\
1.40 \\
5.50\end{array}$ & $\begin{array}{r}.45 \\
1.15 \\
4.50\end{array}$ & $\begin{array}{r}.35 \\
.85 \\
3.50\end{array}$ & $\begin{array}{r}.25 \\
.55 \\
2.50\end{array}$ \\
\hline 1000 & $\begin{array}{r}30.00 \\
.07\end{array}$ & & & & & & $\begin{array}{l}1 \\
3 \\
12\end{array}$ & $\begin{array}{r}1.00 \\
2.50 \\
10.00\end{array}$ & $\begin{array}{r}.80 \\
2.00 \\
8.00\end{array}$ & $\begin{array}{r}.50 \\
1.50 \\
5.00\end{array}$ & $\begin{array}{r}.50 \\
1.25 \\
5.00\end{array}$ & $\begin{array}{r}.40 \\
1.00 \\
4.00\end{array}$ & $\begin{array}{r}.35 \\
.90 \\
3.60\end{array}$ \\
\hline $\begin{array}{l}3 \\
12 \\
100 \\
1000\end{array}$ & $\begin{array}{r}.18 \\
.70 \\
5.00 \\
40.00\end{array}$ & $\begin{array}{r}.15 \\
.50 \\
4.50 \\
32.00\end{array}$ & $\begin{array}{r}.13 \\
.50 \\
3.25 \\
25.00\end{array}$ & $\begin{array}{r}.10 \\
.40 \\
2.50 \\
20.00\end{array}$ & $\begin{array}{r}.30 \\
2.00 \\
15.00\end{array}$ & $\begin{array}{r}.20 \\
1.25 \\
10.00\end{array}$ & $\begin{array}{l}1 \\
3 \\
12\end{array}$ & $\begin{array}{r}1.50 \\
3.75 \\
15.00\end{array}$ & $\begin{array}{r}1.25 \\
3.25 \\
12.60\end{array}$ & $\begin{array}{r}1.00 \\
2.60 \\
10.00\end{array}$ & $\begin{array}{r}.75 \\
2.00 \\
7.50\end{array}$ & $\begin{array}{r}50 \\
1.50 \\
5.00\end{array}$ & $\begin{array}{r}.60 \\
1.25 \\
5.00\end{array}$ \\
\hline $\begin{array}{l}1 \\
3 \\
12 \\
100 \\
1000\end{array}$ & $\begin{array}{r}.08 \\
.20 \\
.80 \\
5.00 \\
48.00 \\
\end{array}$ & $\begin{array}{r}.18 \\
.70 \\
5.00 \\
40.00\end{array}$ & $\begin{array}{r}.15 \\
.50 \\
4.00 \\
32.00\end{array}$ & $\begin{array}{r}.13 \\
.50 \\
3.00 \\
24.00\end{array}$ & $\begin{array}{r}.10 \\
.40 \\
2.25 \\
18.00\end{array}$ & $\begin{array}{r}30 \\
1.50 \\
12.00\end{array}$ & 1 & $\begin{array}{l}2.00 \\
2.50 \\
4.00\end{array}$ & 2.00 & $\begin{array}{l}1.50 \\
3.00\end{array}$ & 1.35 & 1.25 & 1.00 \\
\hline $\begin{array}{l}1 \\
3 \\
12 \\
100 \\
1000\end{array}$ & $\begin{array}{r}.10 \\
.25 \\
1.00 \\
7.00 \\
55.00\end{array}$ & $\begin{array}{r}.20 \\
.80 \\
5.50 \\
44.00\end{array}$ & $\begin{array}{r}.18 \\
.70 \\
4.60 \\
35.00\end{array}$ & $\begin{array}{r}.15 \\
.50 \\
3.25 \\
26.00\end{array}$ & $\begin{array}{r}.13 \\
.50 \\
2.50 \\
20.00\end{array}$ & $\begin{array}{r}.10 \\
.40 \\
1.60 \\
13.00\end{array}$ & 1 & $\begin{array}{l}5.00 \\
6.00\end{array}$ & 6.00 & 4.00 & 3.00 & 2.00 & 1.50 \\
\hline $\begin{array}{l}1 \\
3 \\
12 \\
100 \\
1000\end{array}$ & $\begin{array}{r}.12 \\
.30 \\
1.20 \\
8.00 \\
54.00\end{array}$ & $\begin{array}{r}.10 \\
.25 \\
1.00 \\
5.00 \\
48.00\end{array}$ & $\begin{array}{r}.20 \\
.80 \\
5.00 \\
40.00\end{array}$ & $\begin{array}{r}.18 \\
.70 \\
3.50 \\
28.00\end{array}$ & $\begin{array}{r}.15 \\
.50 \\
2.50 \\
20.00\end{array}$ & $\begin{array}{r}.13 \\
.50 \\
1.80 \\
14.40\end{array}$ & 1 & $\begin{array}{l}7.00 \\
7.50 \\
8.00\end{array}$ & 6.00 & $\begin{array}{l}5.00 \\
4.50\end{array}$ & 3.00 & 2.00 & 1.00 \\
\hline $\begin{array}{l}1 \\
3 \\
12 \\
100 \\
1000\end{array}$ & $\begin{array}{r}.15 \\
.38 \\
1.50 \\
10.00 \\
80.00\end{array}$ & $\begin{array}{r}.12 \\
.30 \\
1.20 \\
8.00 \\
64.00\end{array}$ & $\begin{array}{r}.10 \\
.25 \\
1.00 \\
6.00 \\
48.00\end{array}$ & $\begin{array}{r}.20 \\
.70 \\
4.00 \\
32.00\end{array}$ & $\begin{array}{r}.18 \\
.40 \\
3.00 \\
24.00\end{array}$ & $\begin{array}{r}.16 \\
.30 \\
2.00 \\
16.00\end{array}$ & 1 & $\begin{array}{l}10.00 \\
15.00 \\
25.00\end{array}$ & 12.00 & 10.00 & 7.50 & 5.00 & 4.00 \\
\hline $\begin{array}{l}1 \\
3 \\
12\end{array}$ & $\begin{array}{r}.20 \\
.50 \\
2.00\end{array}$ & $\begin{array}{r}.15 \\
.40 \\
1.60\end{array}$ & $\begin{array}{r}.13 \\
.36 \\
1.20\end{array}$ & $\begin{array}{l}.10 \\
.20 \\
.80\end{array}$ & $\begin{array}{l}.13 \\
.50\end{array}$ & .10 & 1 & 50.00 & 50.00 & 60.00 & 10.00 & 8.00 & 0.60 \\
\hline
\end{tabular}

1

1
12

12

$\begin{array}{rr}1000 & 14.00\end{array}$

1
12
100

$\begin{array}{rr}.20 & .13 \\ .45 & .30 \\ 1.80 & 1.20 \\ 12.00 & 8.00 \\ 80.00 & 54.00\end{array}$

.10
.20
.80
5.00

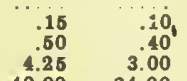

.100
3.00
4.00

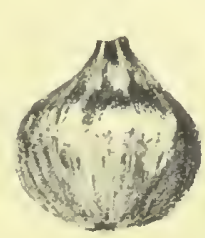

1

1
12
12

$\begin{array}{rr}.25 & .20 \\ .70 & .55 \\ 2.50 & 2.00 \\ 20.00 & 16.00\end{array}$

.15
.45
1.50
10.00

$\begin{array}{rr}.10 & \\ .30 & .20 \\ 1.00 & .50 \\ 7.00 & 4.50\end{array}$

1.00
4.00

.30
.75
3.00
24.00

.25
.55
2.50
18.00

.15
.40
1.50
12.00

.13
.35
1.25

.20
.50

.50

1
3
12

.50
1.25
5.00

.40
1.00
4.00
20.00

.30
.75
3.00
16.00

$\begin{array}{rrr}.20 & 15 & .10 \\ .60 & .40 & .25 \\ 2.00 & 1.50 & 1.00 \\ 12.00 & 8.00 & 5.00\end{array}$

3

$\begin{array}{rrrrr}.60 & .40 & .30 & .25 & .20 \\ 1.25 & 1.00 & .75 & .55 & .50 \\ 5.00 & 4.00 & 3.00 & 2.50 & 2.00\end{array}$

.10
.25
.70
5.00
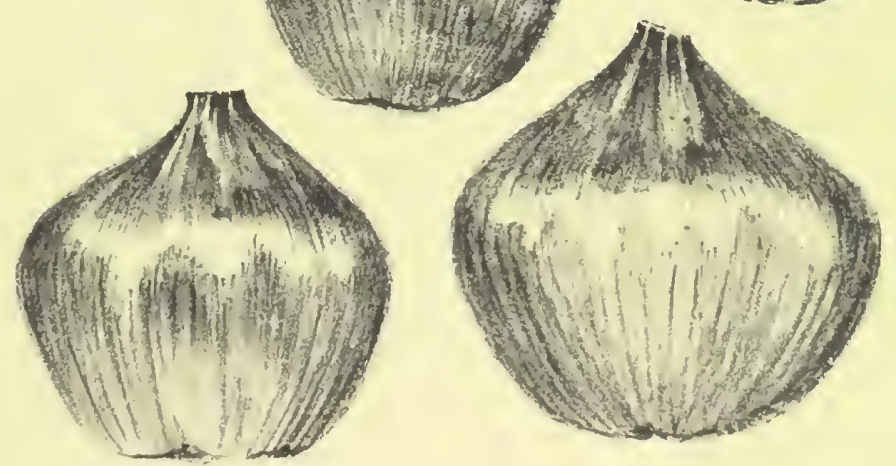

Our Motto:

Healthy, Young, True-to-name Stock 
Copyright 1932

Colonial Gardens 